\title{
THE IRON AND STEEL INDUSTRY IN 2009
}

\author{
December 2009
}

\section{Introduction}

The global steel industry is now recovering from one of its worst recessions since the early 1970s. After declining sharply in the second half of 2008, global steel consumption began to stabilise in the first half of 2009 and has been gradually recovering since then. The stabilisation was due primarily to the strong recovery in Asian demand led by China (Figure 1). The swift turnaround in Chinese steel consumption has been supported by government stimulus spending on infrastructure and the rapid credit expansion to offset the impact of weak exports on demand. India is another of the few economies in the world to have avoided recession. This is reflected in India's steel consumption, which has increased considerably during 2009 on the strength of activity in the construction and automotive sectors. Egypt and Iran also recorded strong steel consumption growth in 2009 , supported by construction in housing and projects related to the oil sector, respectively.

Elsewhere in the world, demand conditions are now beginning to stabilise. The destocking cycle was so abrupt and steep in the first half of the year that inventories were brought down to extremely low levels, even relative to underlying demand. Although underlying demand is still very weak across the OECD region, inventory rebuilding as economic activity begins to gradually improve is having a positive effect on apparent steel consumption. In South America demand is starting to improve particularly in Brazil, where government tax policies are stimulating domestic car purchases as well as construction activity. In Southeast Asia, demand for steel contracted sharply in the first half of 2009. External demand for the region's manufactured goods, coupled with low inventories, is now feeding through to increased industrial production and higher steel demand.

This stabilisation of demand, and nascent recovery in some economies, has helped lift steel prices in all regions of the world since last summer (Figure 2). Asian prices were the first to recover, particularly in China where prices of long steel products rose by $31 \%$ between March and August in response to robust infrastructure construction. Despite the recent improvement, average steel prices are still down $33 \%$ in Asia, 44\% in North America, and 52\% in the EU compared to the highs observed in the summer of 2008. 
Figure 1: World consumption of steel

Millions of tonnes
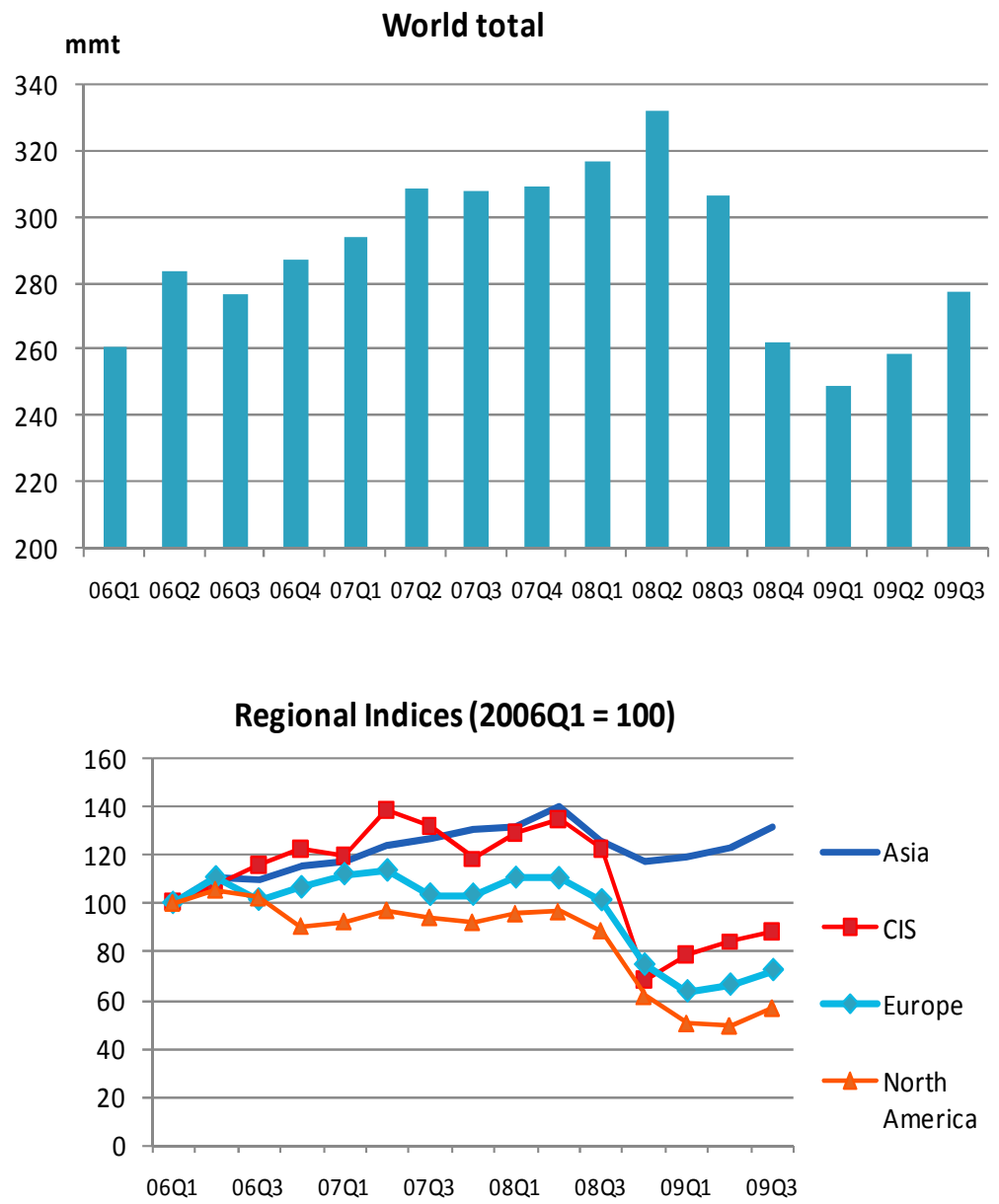

Source: CRU 
Figure 2: Steel prices by region
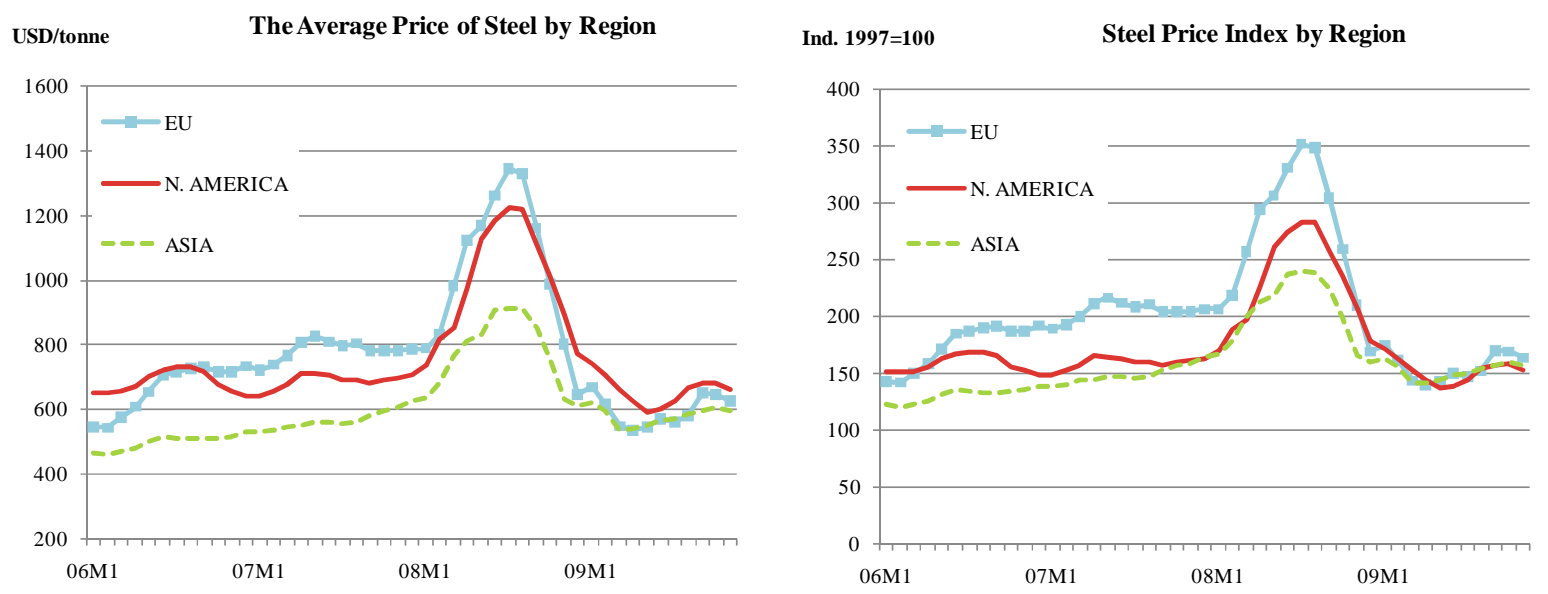

Note: Prices are a weighted average price of flat and long product categories, converted into USD using exchange rates at the start of the month.

Source: MEPS International Ltd.

Steelmakers around the world have re-started furnaces in response to the improved demand situation and world production has recovered over the past two quarters (Figure 3). As a result, capacity utilisation rates have risen in recent months from the very depressed levels of the beginning of 2009, even in North America, the EU and Japan. North American crude steel production was running at annualised rates of 9095 million tonnes in August to October. Capacity utilisation is back up to around 61\%, though still well below normal rates. In the EU, many steelmakers have relit blast furnaces, and production is now $40 \%$ higher than at the beginning of the year. In the low-cost CIS region, producers have responded to rising prices by ramping up production, much of which is destined to meet demand in foreign markets. Ukrainian output is already seven percent higher than the pre-crisis, September 2008 level.

However, given the weak development in the beginning of the year, most regions will record steep, doubledigit production declines for 2009 as a whole. China is an exception, where production is on track to rise by approximately $15 \%$ in 2009 to a level above 570 million tonnes. The Middle East and India should also record output increases over 2008. China's share in world steel production has risen to $48 \%$ during 2009 (Figure 4).

World steelmaking capacity is projected to rise from 1,806 million tonnes in 2009 to 1,986 million tonnes in 2012, as producers resume many of the expansion projects that were put on hold in the aftermath of the economic crisis (Figure 5). Most of the capacity additions in the future will take place in developing Asia, particularly in China and India. Some growth is also expected for South America and the Middle East. Capacity should remain more or less stable in North America and the European Union in the coming few years. 
Figure 3: World crude steel production

Millions of tonnes
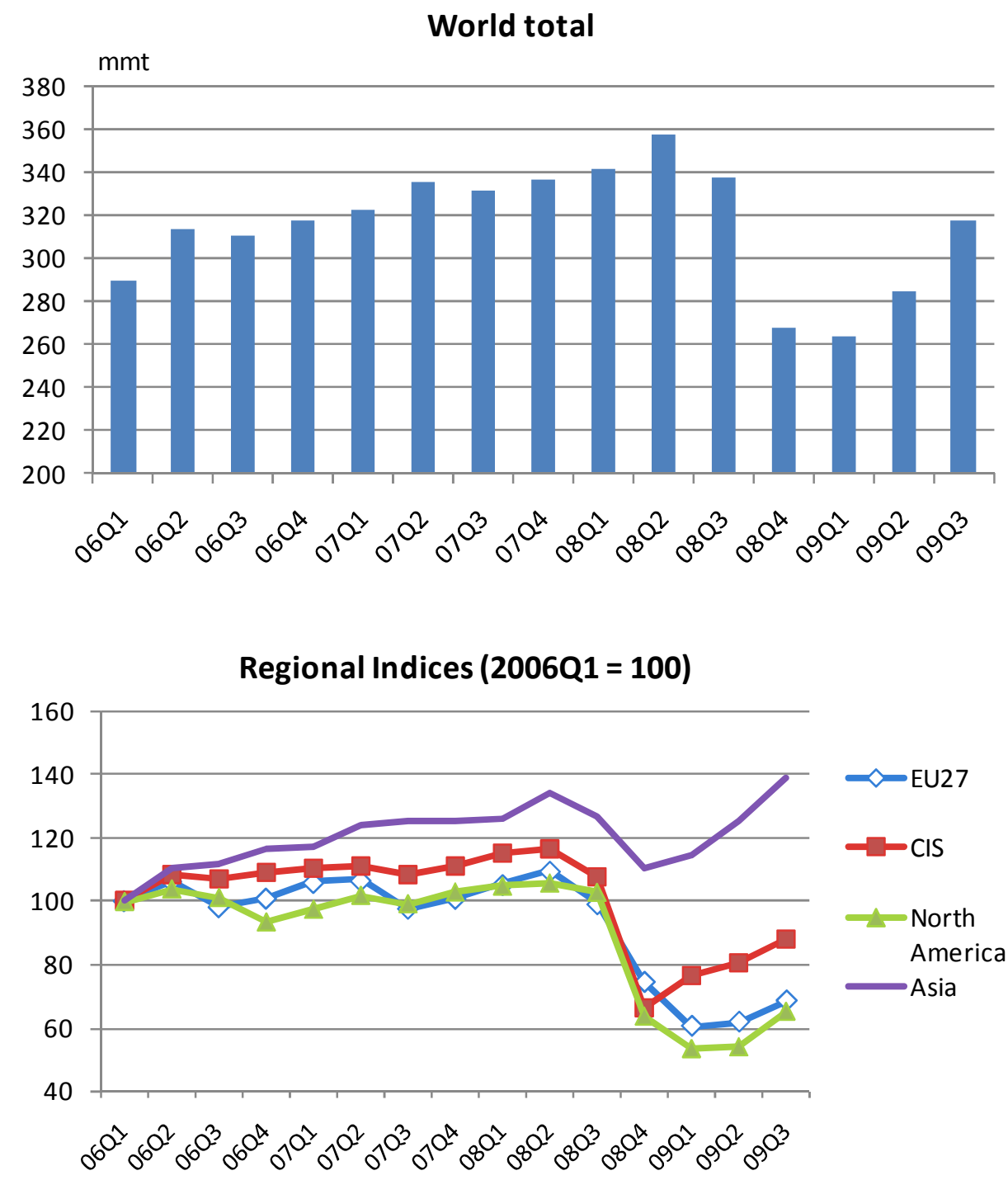

Source: World Steel Association 
Figure 4: Share of world steel production by region in 2009

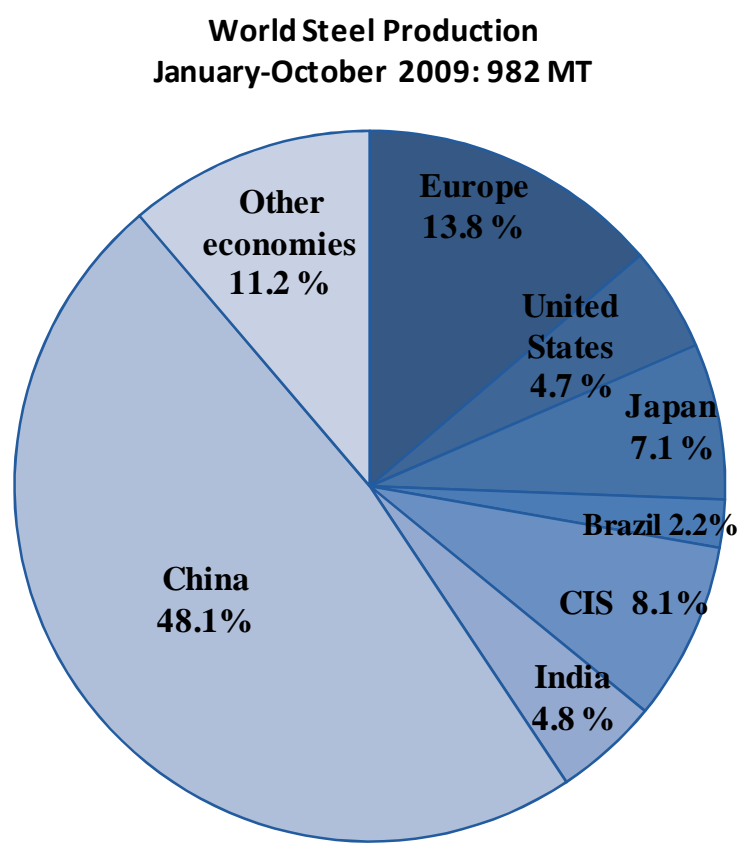

Source: World Steel Association

Figure 5: World crude steelmaking capacity and share by region, 2009-2012
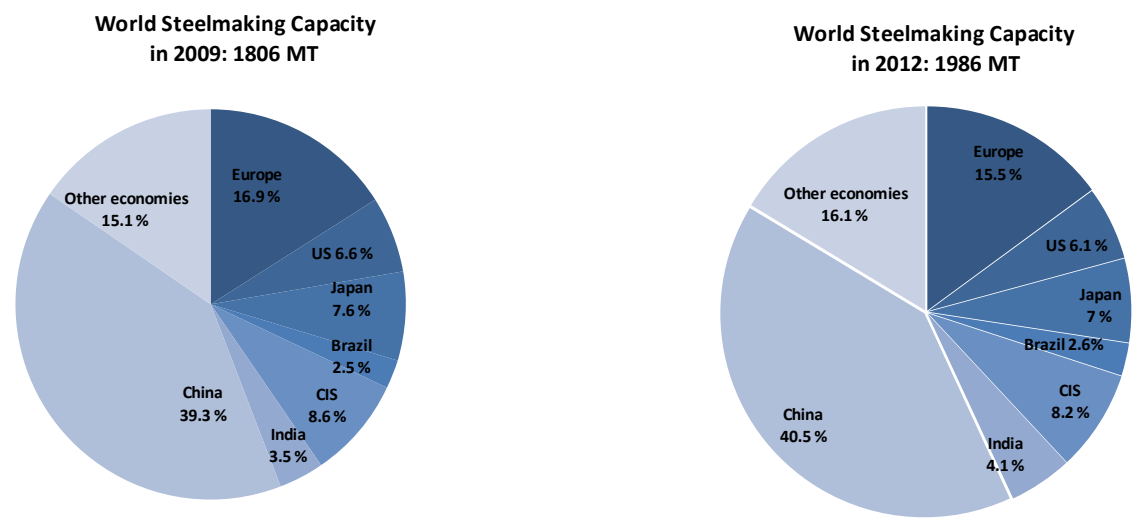

Source: OECD 
Following an extended period of robust growth, the volume of steel trade plunged in the final quarter of 2008 and into the first quarter of 2009 . According to monthly figures ${ }^{1}$, major exporters' cross-border shipments of steel declined to 50 million tonnes in the fourth quarter of 2008, down $30 \%$ from the previous quarter and $18 \%$ from a year earlier. For 2008 year as a whole, however, global exports declined by only two percent to 250 million tonnes, owing to the strong trade performance observed through most of the year. The first quarter of 2009 saw another contraction in exports, by $16 \%$ in quarter-on-quarter terms, to 42.4 million tonnes. Since then, export volumes have recovered slightly, reaching 46 million tonnes in the second quarter of the year.

Export trends by economy have been divergent in the first half of 2009. While some major steel producers have seen exports recover in the first half of 2009, China and the United States have seen shipments stagnate at the low levels of end-2008 (Figure 6). Meanwhile, most economies are still experiencing sharp declines in imports, with the exception of China, where monthly import levels have more than doubled in recent months compared to the end of 2008 (Figure 7). This reflects China's strong steel demand, while that of developed economies remains weak.

\footnotetext{
${ }^{1}$ World export figures are OECD estimates based on monthly data for the ten largest exporters (Brazil, China, Chinese Taipei, Japan, the EU, Russia, South Korea, Turkey, Ukraine, and the U.S.). These economies accounted for $86 \%$ of total exports in 2007. The figures exclude intra-EU trade.
} 
Figure 6: Monthly exports of steel, January 2007-September 2009

Thousands of metric tonnes by selected economies
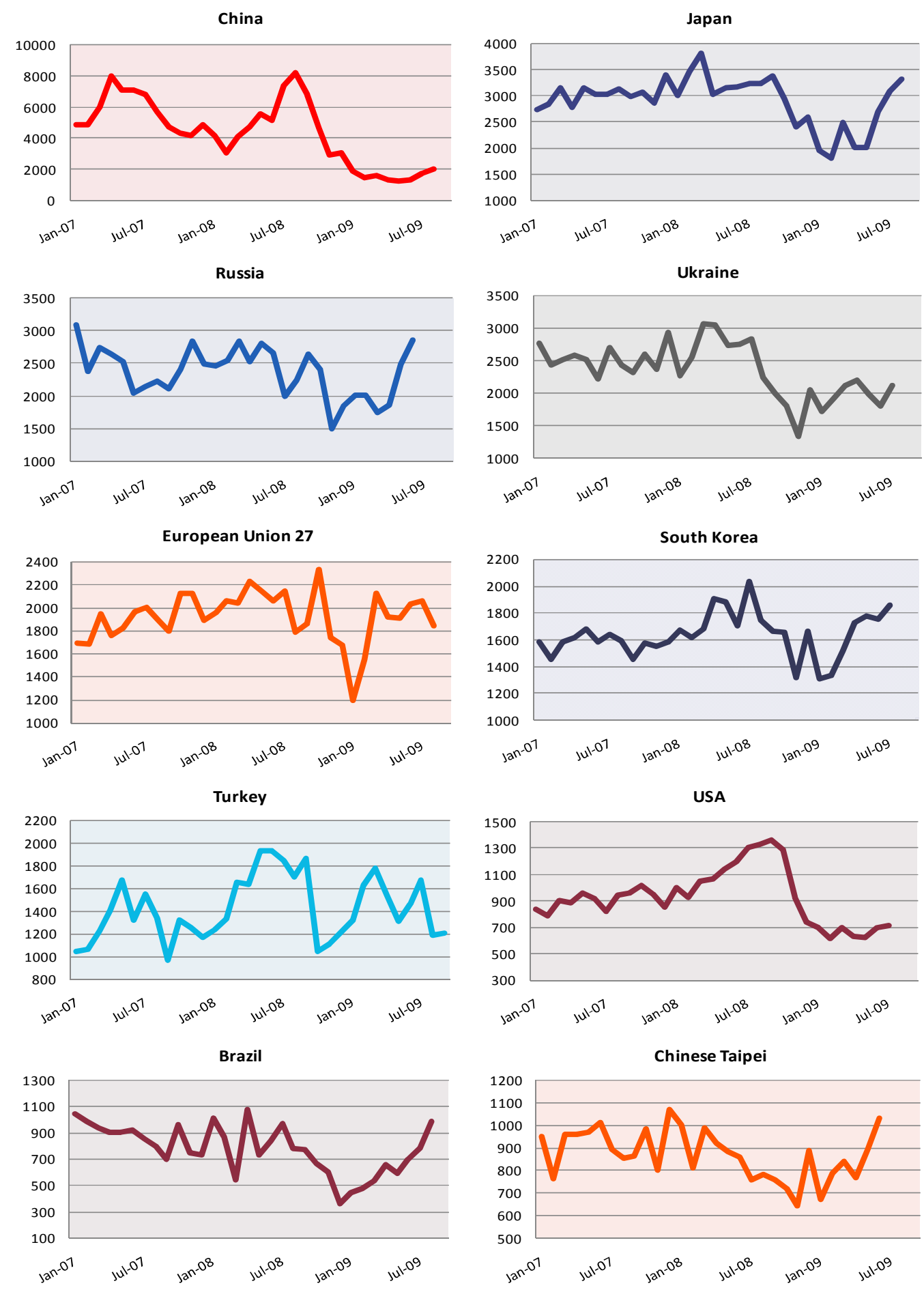

Source: The World Steel Association, EUROFER and ISSB. 
Figure 7: Monthly imports of steel, January 2007-September 2009

Thousands of metric tonnes by selected economies
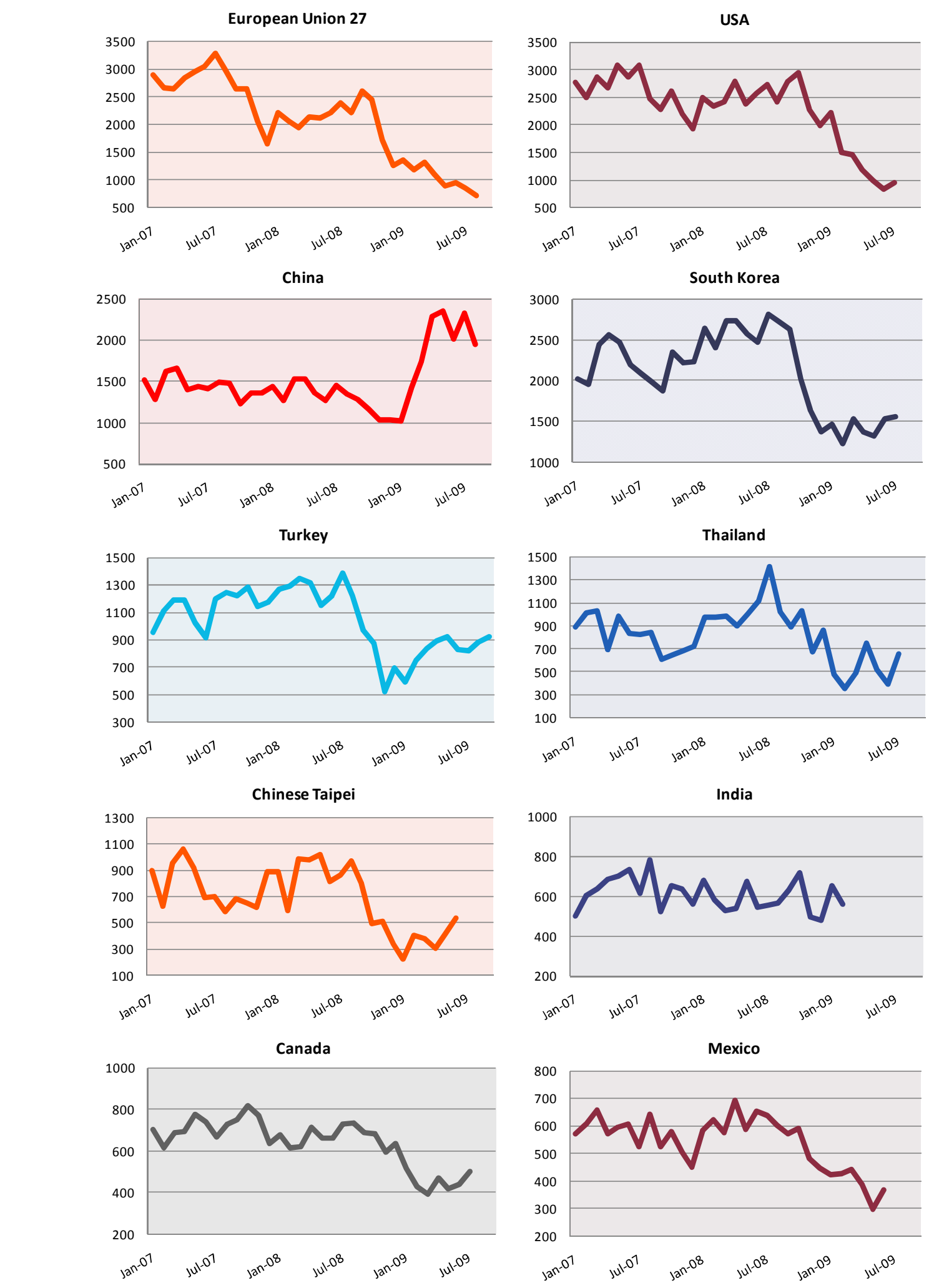

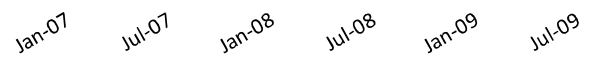

Source: The World Steel Association, EUROFER and ISSB. 


\section{Regional Market Developments}

North America

Steel demand in North America deteriorated rapidly in the last few months of 2008 and into the first part of 2009, as steel-consuming manufacturers cut output in response to plunging sales and construction activity contracted sharply. Steel producers, who traditionally respond very closely to demand fluctuations, moved swiftly to cut their production, doing so by around 50\% between September and December 2008.

The contraction in demand, production and prices continued through most of the first half of 2009, but then began to bottom out during the summer of 2009. With the overall economy now recovering, steel market conditions in North America are beginning to show improvement, but from very depressed levels. The restocking cycle is pushing consumption levels higher, evidenced in the $15 \%$ quarterly increase in North American steel consumption in the third quarter of 2009, to an annualised level of 77 million tonnes.

Monthly steel production in North America rose to 7.5-8 million tonnes in August-October 2009, up from monthly levels well below 6 million tonnes during the first half of the year. While electric-arc furnaces were able to come back on line first, production increases are now being supported the re-starting of blast furnaces as well. This brings the region's capacity utilisation rate up to approximately $61 \%$, the highest since October 2008. However, capacity utilisation is still well below rates of around $88 \%$ observed during the 2004-07 market upturn.

Steel trade in North America has declined substantially. Imports of steel have contracted on a monthly basis since November 2008 in response to extremely weak demand conditions. In June, they had fallen to 1.6 million tonnes, down nearly $60 \%$ from monthly levels seen in the latter part of 2008. Exports have not declined nearly as much, and this has helped contribute to a sharp decline in the region's traditionally large steel trade deficit. As a result of weak domestic demand, in the first half of 2009 NAFTA's external deficit with the rest of the world declined to 5 million tonnes, compared to a deficit of 18 million tonnes in 2008. The region nevertheless remains a large net importer.

Steel market conditions are generally expected to improve in the region in 2009-2010 from their currently depressed levels. The improvement is not so much one of recovery, but represents more of a correction towards more sustainable conditions following a period in which the industry suffered a larger contraction than the overall economy. The consumption of steel should pick up considerably in the remainder of 2009, supported at least by a technical inventory correction as manufacturers move to refill their depleted stocks.

The significant increase in consumption expected for the second half of 2009 implies a large "carryover effect" for 2010. That is, even a constant level of consumption during 2010 would generate a large percent increase in consumption that year compared to 2009. Factors that might constrain demand growth in 2010 include slow household income growth due to high unemployment, which will continue to curb spending on major durable goods. Moreover, consumer debt will remain high and wealth has been depleted. Some key indicators of housing are showing signs of stabilisation, but overall growth in construction in 2010 will be held back by weak non-residential building investment. Automobile production expectations have improved, helped by scrapping schemes which have boosted sales and reduced vehicle inventories to very low levels. However, in the future, vehicle sales and production could be affected by the so-called "payback effect," i.e., sales that were pulled forward to 2009 will not occur in 2010.

Steel demand in 2011-2012 is expected to continue recovering as the regional economy returns to trend GDP growth of 3-3.5\%. However, consumption may not return to the pre-crisis level for several years. Key end-using industries, such as automotive, consumer durables and mechanical engineering, are expected to recover only gradually, overshadowed by structural factors such as overcapacity in the automotive sector, 
high household debt and saving ratios (with implications for spending on consumer durables) and, possibly, negative impacts from rising long-term real interest rates due to high government debt on private investment in machinery.

NAFTA steelmaking capacity is likely to be higher than demand in the coming years. Following a process of industry restructuring and facility closures in the early 2000s, steelmaking capacity in the NAFTA region increased gradually until 2007 in response to stable steel demand. Steelmaking capacity is projected to rise slightly over the next few years, from its current level of around 155 million tonnes to 157 million tonnes by 2012 .

Figure 8: North American steel prices
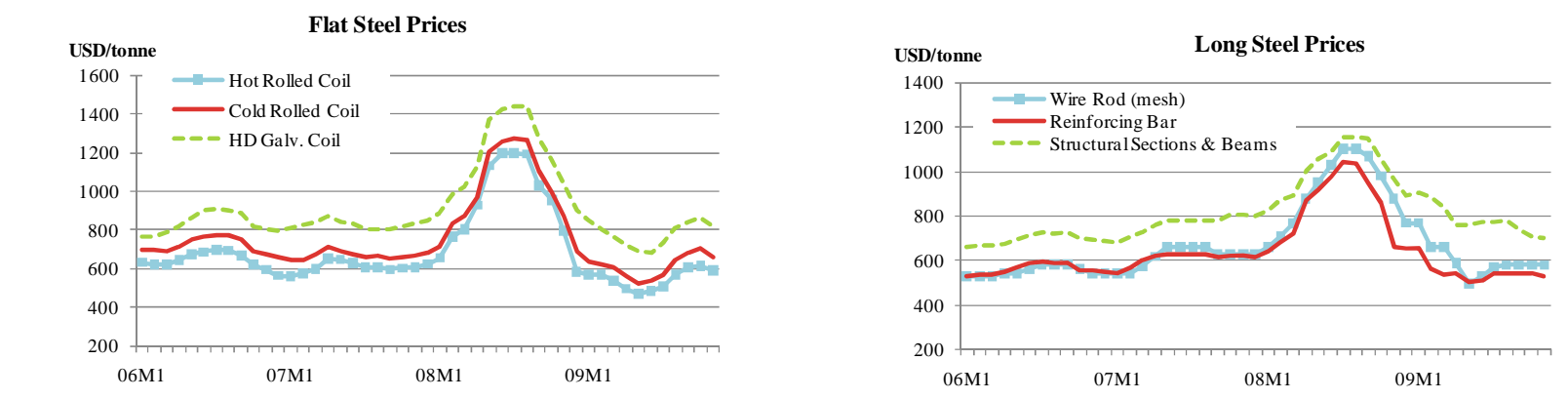

Source: MEPS International Ltd.

Europe

The European Union enjoyed a period of favourable demand growth in 2006-2007, supported by strong construction activity in eastern and southern Europe and growing output in the automobile and machinery industries. In 2008, moderate steel demand growth through most of the year gave way to a sharp contraction in the last few months of the year, as important end-using industries such as construction, automotive, and mechanical engineering cut output sharply in response to the collapse in domestic and foreign demand for industrial goods.

The contraction in apparent consumption of steel accelerated in the first half of 2009 to $45 \%$ year-on-year, reflecting continued destocking and weaker demand from end-using industries. As a result of the steel inventory liquidation, inventory-to-sales ratios have declined in recent months near to their longer-term averages in some countries. As a result, demand now appears to be stabilising, with preliminary data pointing to positive growth in the third quarter relative to the second quarter. Demand for flat steel products, in particular, has benefited from the revival of car demand resulting from scrapping schemes introduced recently in many countries.

Steelmakers in Europe took strong measures to cut back on production and achieve a more sustainable supply-demand balance through the first half of 2009, bringing the region's capacity utilisation rate down to $50 \%$. However, with demand now starting to pick up, many steel producers have brought idled capacity back into operation. By October 2009, monthly production in the EU had risen to more than 14 million tonnes, up $40 \%$ from the beginning of the year and only $12 \%$ lower than a year earlier. A strong decline in imports is also helping to keep supply and demand in balance. As a result, the trade balance has moved into surplus territory, with exports exceeding imports by approximately four million tonnes in the first half of 2009. 
The steel market outlook for the remainder of 2009 and 2010 has improved slightly on the back of more positive economic data. Easing credit conditions, monetary and fiscal policy interventions, a turn in the industrial inventory cycle, and an improving outlook for the world economy should help to moderate the decline in real demand for steel. Moreover, the more normal inventory situation could lead to a significant increase in new orders in the near term. However, reflecting the weak first half of 2009, forecasts by the World Steel Association point to a decline in EU-27 steel consumption of 32.6\% in 2009, almost the same rate of contraction as that projected for NAFTA.

In 2010, the World Steel Association expects a resumption of growth to $12.4 \%$, but this would leave apparent use of finished steel at 137 million tonnes, still 30\% below the 2007 level. Much of the growth in 2010 may be attributable to a technical inventory correction, as the mere end of destocking would generate large growth in apparent steel use, while fundamental end-use demand remains relatively modest. Construction activity will be held back by weak activity in the non-residential segment. While scrapping schemes have led to increased sales and considerable declines in vehicle inventories in 2009, this trend could be reversed in 2010 as these schemes gradually come to an end. Indeed, in some countries car sales are currently well above their long-term trend, suggesting the possibility of a sharp downward correction in the near term. Moreover, the European labour market will remain very fragile which could weigh on consumption of steel-intensive durable goods. Moreover, the mechanical machinery industry might continue to suffer from sluggish investment activity.

In the early 2000s, EU steelmaking capacity was around 240 million tonnes and crude steel production was slightly above apparent consumption. Though a net exporter at the time, the EU became a net importer during 2006 and 2007 owing to favourable demand growth and large increases in imports. Until recently, there had been only a few capacity expansions because companies invested less in upstream expansion but more in energy-saving measures, quality improvement technologies, as well as for rationalising, restructuring and consolidating activity. Steelmaking capacity is projected to remain unchanged at 250 million tonnes until 2012.

In "Other Europe" (comprised of Norway, Switzerland, Turkey and some countries created from the former Yugoslavia), steelmaking capacity increased steadily in recent years, supported by growing steel demand in the region and nearby Middle Eastern and North African markets. In spite of the steel market downturn, many expansion projects are progressing because steel producers expect consumption in the region and neighbouring markets to recover over the medium term. Capacity is projected to increase steadily from 44 million tonnes in 2009 to 52 million tonnes in 2012, dominated by developments in Turkey.

Figure 9: European Union steel prices
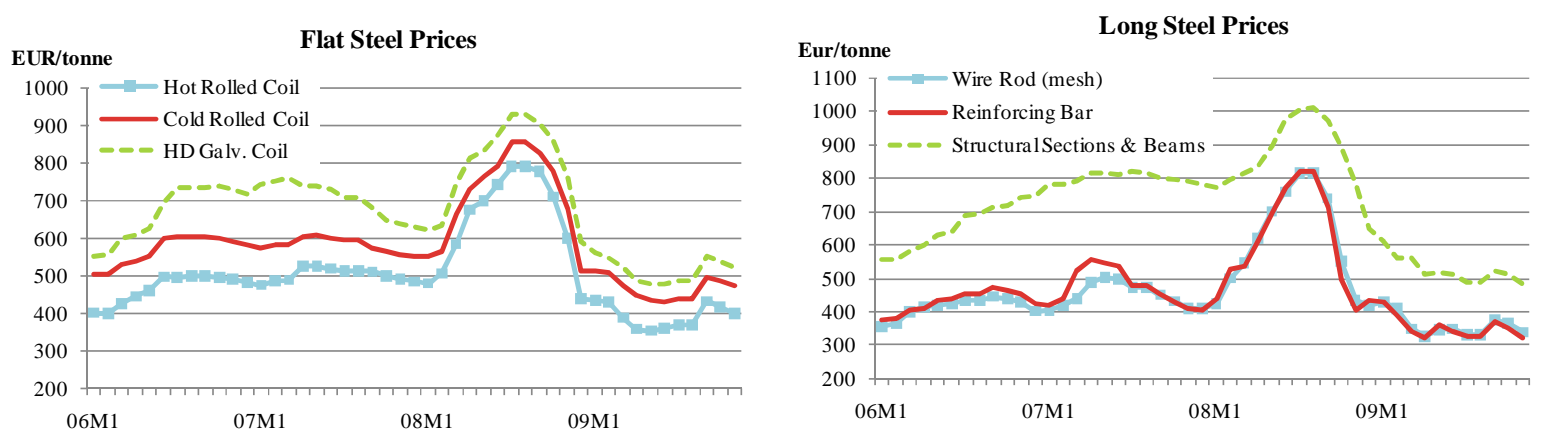

Source: MEPS International Ltd. 
The Asian steel industry has driven global market trends over the last few years, thanks to rising incomes, rapid growth in fixed asset investment, significant infrastructure spending, increasing global demand for regional exports, as well as strong urbanisation trends in developing economies. While the region's percapita consumption of steel was only $70 \%$ of the global average in 2000 , the gap has now closed as annual steel consumption has risen to 187 kilograms per person. China's steel use per capita has nearly tripled during this period, and has reached levels similar to those in the United States and some EU countries. India's per-capita consumption has almost doubled, and even South Korea, with the world's highest per capita consumption, has seen a further increase. Japan and Chinese Taipei, on the other hand, have seen a decline in consumption per capita, though from very high levels.

Figure 10: Asian steel prices
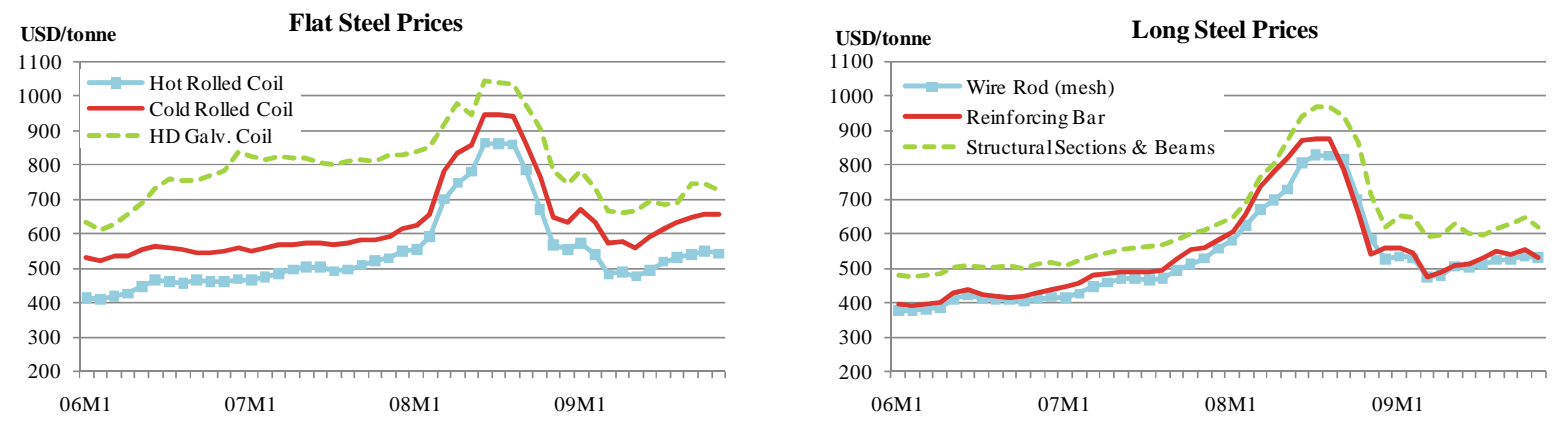

Source: MEPS International Ltd.

\section{China}

China, where production surpassed the half-billion mark in 2008, is one of the only economies (along with India and Iran) to have produced more steel in the first ten months of 2009 relative to same time period in 2008. Chinese crude steel production has increased by $10 \%$ to date in 2009 , and imports have increased by $29 \%$, to meet rapid growth in demand. Production growth has accelerated markedly since August, picking up to $29 \%$ in September and $42 \%$ in October 2009, in year-on-year terms.

Growth in demand (forecast by the World Steel Association at 19\% in 2009) in China is strongly supported by the large fiscal stimulus package and public investment plans, particularly in infrastructure and lowincome housing by local government entities, and surging bank loans which have supported investment. Robust growth in infrastructure construction has more than offset the effects on demand from the slowing real estate market and lower exports in the beginning of the year. Investment in railway projects, in particular, has grown strongly. As a result, Chinese consumption and production of long steel products have increased considerably, and prices of products such as rebar have risen. According to the China Metallurgical Newsletter, apparent consumption of long products in January-September 2009 increased by $27 \%$ while output was up $19.1 \%$.

It appears that the majority of the stimulus spending is likely to have been undertaken throughout 2009. Recent statistics show that transport infrastructure spending increased by $50 \%$ in the first ten months of 2009 , to about $79 \%$ of the government's fiscal 2009 target. Railway spending was up approximately $78 \%$, highways $47 \%$, waterways five percent, urban public transport $54 \%$, and air transport $15 \%$. In addition, media reports suggest that around half of the budgeted expenditure for post-earthquake reconstruction had 
been spent by the end of October 2009, with many of the residential building and infrastructure projects having already been completed.

The stimulus-led economic growth in 2009 has therefore been extremely steel intensive. However, with the fiscal deficit approaching 5\% of GDP, there are doubts about whether such spending can be sustained in the future. The Worldsteel Association forecasts an increase of almost 19\% in Chinese apparent steel use in 2009 , followed by a slowdown in growth to $5 \%$ in 2010.

Over the longer term, Chinese steel demand growth could slow in response to a shifting economic structure away from investment and towards consumption. The exceptionally fast pace of fixed asset investment growth observed since the turn of this century may have led to overcapacity in the Chinese economy and key industrial sectors, including steel. As a result of faster investment growth than GDP, the ratio of gross fixed capital investment to GDP rose above $40 \%$ in 2008, a level that many observers consider as unsustainable over the longer term. Fixed asset investment growth accelerated further during 2009, leading to a further rise in the investment-to-GDP ratio. Some economic studies suggest that the efficiency of investments in China has declined significantly recently, which could eventually lead to an extended period of more moderate investment activity. At the same time, policies to increase consumption would lead to lower household savings and lower fixed asset investment.

Chinese steelmaking capacity was lower than steel demand in the early 2000s. Responding to the brisk growth in demand, a large number of expansion projects were started across the country. However, with capacity expanding at a more rapid pace than domestic steel demand, and with many of these expansion projects not meeting environmental standards effectively enough, the accumulation of inefficient overcapacity especially amongst small and medium-sized firms has become a major concern in the country.

Since 2003, capacity has exceeded steel demand and the gap has widened. The government has tried to reign in steelmaking capacity with tighter restrictions on the construction of new steelmaking facilities and the operation of outdated facilities, as well as by introducing several environmental regulations. Although the financial crisis had a significant impact on steel industry, the government's stimulus package has promoted faster economic growth, leading to a strong recovery in steel demand. With the economy growing rapidly, Chinese steelmaking capacity has continued to increase, and is forecast to reach slightly more than 800 million tonnes by 2012. In light of the situation, the government has introduced a series of policies aimed at constraining capacity.

\section{India}

India's steel industry, the world's fifth largest, has been relatively resilient to the global economic slowdown, and steel demand and output are now increasing again. This reflects the fact that India's economy is driven primarily by domestic demand, with exports accounting for a relatively small share of GDP. Unlike in many other countries, steel production volumes in India were not significantly affected at the end of 2008, and for the year as a whole rose by $3.8 \%$ to 55.1 million tonnes. Crude steel production remained roughly stable in the first ten months of 2009 , rising slightly by two percent relative to the corresponding time period in 2008.

Steel consumption has recovered faster than expected in 2009, at a pace of $7 \%$ in the first seven months of the 2009 fiscal year. Demand has been supported by growing output in the automobile sector, household appliances, construction and infrastructure. The construction and infrastructure sector in the country has been the fastest growing in recent years, contributing to strong demand particularly for long products. The capital goods and automotive sectors have also boosted steel demand. In recent months, Indian car production has increased at rates of more than $10 \%$. 
The relatively low level of investments to date in infrastructure and the relatively small share of heavy industry and construction in the Indian economy mean that per capita consumption of steel is extremely low in international comparison (only $43 \mathrm{~kg}$ in 2008 compared to a world average of $194 \mathrm{~kg}$ ). This relatively low level of steel consumption reflects the fact that heavy industry and construction account for only one fourth of India's GDP, while services contribute the most to the economy. This is very different from the situation prevailing in China, where heavy industry and construction make up more than half of GDP.

The country's low per capita consumption suggests that there is a large potential for greater use of steel in the economy. As a result, India will probably see major expansion of steel demand in the future, owing to high population growth and the need for housing, rising incomes, as well as significant public investment in infrastructure projects including railways, ports, and roads. The World Steel Association forecasts demand growth of $8.9 \%$ and $12.1 \%$ in $2009-2010$, respectively.

Local and foreign steelmakers have had planned significant capacity expansions in order to keep supply in line with optimistic expectations for demand. The National Steel Policy of 2005 had projected consumption growing at seven percent per annum based on a GDP growth rate of 7-7.5\% and production of 110 million tonnes by 2019-2020. Since then, the Ministry of Steel has upgraded its assessment of the industry's growth. According to the Ministry's 2008-2009 Annual Report, the government expects steel production capacity to reach nearly 124 million tonnes already by the fiscal year 2011-12. Moreover, the industry is expected to generate additional employment of around 4 million by the year 2020, with production of crude steel reaching around 295 million tonnes by 2019-2020.

The Ministry notes that 222 memorandums of understanding (MoUs) have been signed with various States for a planned capacity of around 276 million tonnes. With many of the greenfield steel mill projects encountering strong popular resistance, and given the impact of the financial crisis, some steelmakers have been forced to shelve or postpone their projects. However, several integrated steel mill projects will continue and are expected to be completed in two or three years' time. Steelmaking capacity is projected by the OECD to increase to 100 million tonnes by 2012 .

\section{Southeast Asia}

The Southeast Asian economy is now rebounding in line with the broader Asian economic recovery. Southeast Asia is traditionally a large importer of steel, primarily of semi-finished products for further processing by the region's large number of re-rollers. Despite a significant drop in steel consumption in the second half of 2008, ASEAN demand grew by $5.7 \%$ to nearly 46 million tonnes for the year as a whole due to strong growth until the onset of the financial crisis.

However, trends varied considerably across countries. Indonesia showed the most resilience to the global downturn, with steel consumption expanding by almost $22 \%$ to 8.8 million tonnes in 2008 , driven by construction and the automotive sectors. Thailand, the largest consumer in the region, recorded a $7 \%$ increase in demand to 13.5 million tonnes on the back of expansions in the automotive and electrical appliances sectors. Malaysia suffered a 50\% drop in consumption in the second half of 2008, but favourable construction activity in the first half of the year resulted in an overall $7.6 \%$ increase in consumption to 8.3 million tonnes in 2008 . Vietnamese consumption declined sharply in 2008 as a whole.

ASEAN demand fell further in the first half of 2009, declining to 16 million tonnes from 20 million tonnes in the second half of 2008. In late 2008, many steel producers announced production cuts of $40-60 \%$, as many construction projects, the biggest steel-consuming sector, were delayed or cancelled. Since then, production has increased slightly, to 10.6 million tonnes in the first half of 2009 from 10 million tonnes in the second half of 2008, leading to a significant decline in the region's net imports of steel. Recovering 
external demand for manufactured goods, coupled with low inventories are now leading to increased industrial production in the region, which should feed into slightly higher steel demand and production in the second half of the year and into 2010.

Before the global downturn, when regional steel demand was booming in response to strong infrastructure spending and rising exports, the region's steelmakers had planned on raising the domestic production capacity of pig iron and crude steel and had various integrated steel mill projects in sight. Although some large integrated steel projects have been cancelled or postponed due to the market downturn and delays in procuring building sites, ASEAN6 ${ }^{2}$ steelmaking capacity is projected to increase gradually to 40 million tonnes by 2012 owing to stable investment which is aimed at meeting growing steel demand

\section{Japan, South Korea and Chinese Taipei}

For several years until the onset of the global financial crisis, the steel industries of Japan, South Korea and Chinese Taipei had enjoyed favourable market conditions, supported by growth in the automobile, shipbuilding and machinery industries. South Korea, in particular, has enjoyed very rapid growth in steel consumption, which reached almost 59 million tonnes in 2008. While Korea's fast demand growth relative to production has made it a small net importer of steel, Japan and Chinese Taipei have experienced slower domestic demand developments and sustained net exports.

These three export-oriented and manufacturing-intensive economies were hit hard by the abrupt global slowdown and collapse in external demand. Weakening demand for durable goods such as automobiles, and slumping investment activity in the region, depressed manufactured exports and industrial production significantly at the end of 2008 and early part of 2009. The export shock fed through to domestic demand, through lower investment and consumption, which hurt steel demand in sectors such as construction and mechanical engineering and equipment. All three economies registered sharp, double-digit declines in demand, production, and trade in the beginning of 2009.

These economies are now recovering at a relatively fast speed, as seen in indicators of industrial production which resumed positive growth already in the second quarter of 2009. Reflecting this, steel demand stopped declining already in the second quarter in Japan, South Korea and Chinese Taipei, earlier than elsewhere, and positive growth was observed in the third quarter. According to data from CRU, demand in Japan and Chinese Taipei was 33\% higher in the third quarter relative to the first quarter, while in South Korea it was 17\% higher. As a result, steelmakers have re-started blast furnaces, and the aggregate capacity utilisation for these three economies has recently been brought back up to $83 \%$ from the nadir of $55 \%$ seen in February 2009.

Demand prospects for 2009 as a whole are weak, with the World Steel Association forecasting a consumption decline of almost $28 \%$ for these three economies as a whole. Though government spending on infrastructure and civil engineering will provide some support to steel demand, sharp declines in private construction activity and car production are driving the downturn. The World Steel Association forecasts demand to increase by $16 \%$ in 2010 , as the regional and global economies recover.

Turning to capacity, Japanese steelmaking capacity declined significantly in 2002-2003, but then increased steadily as steps were taken to upgrade steel facilities. In South Korea and Chinese Taipei, where rolling capacity is much higher than iron and crude steelmaking capacity, capacity continued to increase in response to steady investment in steelmaking facilities. The global financial crisis forced steel companies to scale down production following sharp declines in demand. Capacity utilisation in the steel industry fell significantly at the end of 2008 and the beginning of 2009. In South Korea and Chinese Taipei,

\footnotetext{
${ }^{2}$ Indonesia, Malaysia, Philippines, Singapore, Thailand and Vietnam.
} 
steelmaking capacity is projected to show a large increase in the coming years, with several new integrated steel mill projects being completed by 2012. On the aggregate, steelmaking capacity is projected to increase from 220 million tonnes in 2009 to 231 million tonnes in 2012.

\section{Russia and Ukraine}

Russia and Ukraine were hit severely by the global economic downturn, as export earnings from allimportant ferrous metal exports plunged, banking sectors came under stress, and as falling oil and other commodity prices led to deteriorating financial conditions amongst major enterprises. The sudden reversal in capital flows has led to a contraction in fixed investment and, in turn, has depressed steel demand. As a result of the downturn, the debts of metallurgical companies have risen sharply, and efforts are now being made to restructure debt through cost reductions and efficiency improvements. Investment activity in the Russian steel industry has also declined significantly in recent months.

Prior to the downturn, the Russian and Ukrainian steel industries had enjoyed rapid growth, supported by abundant raw materials and very low production costs. Both countries produce well over domestic consumption, and are large net exporters of steel. Ukraine is unique in this regard, as it has the highest export ratio in the world, typically more than $70 \%$, and is also the world's third largest exporter in absolute terms.

These countries are still experiencing deep recessions in steel consumption. However, since costs are so much lower than elsewhere, the gradual recovery in world steel prices above the marginal cost of production has spurred increases in steel output in recent months, leading to some growth in exports.

In Russia, apparent steel consumption continued to contract by more than $40 \%$ in the first half of 2009 . However, production fell less owing to the improving export development. As a result, Russian net exports generally rose during 2009. Russian production has been increasing in more recent months, and in October 2009 was only eight percent lower than the September 2008 level. Ukraine has also ramped up production recently in response to strengthening steel prices, and in October production was already seven percent higher than the September 2008 level.

The outlook for steel consumption in Russia and Ukraine is very subdued, as major steel-using sectors are still experiencing very negative growth and slow recovery prospects. Recent economic forecasts suggest that Russian economic growth will gradually pick up in 2010-2011, helped by some consumption growth and an improved export outlook as the world economy recovers, though much will depend on future oil price developments. More importantly for steel is fixed investment, however, of which there is considerable uncertainty due to the difficulties and cost of obtaining finance. At the same time, investment is key to longer term growth in Russia owing to the aging capital stock.

Russia and Ukraine are major net exporters of steel products. Prior to the recent downturn, steelmakers in these countries had planned major capacity expansion projects. These included several mini-mill projects and the replacement of outdated open-hearth furnaces with new basic-oxygen and electric-arc furnaces. However, the global financial crisis and falling demand have forced steelmakers to reduce production and downgrade their investment plans. Currently steelmakers are gradually restoring their facilities to normal operating levels and investing in energy-saving technologies. Steelmaking capacity for the entire CIS region is expected to increase modestly to 160 million tonnes by 2012. 
The South American economy contracted in the fourth quarter of 2008 and the first quarter of 2009, as investment, consumption, and exports fell. Approximately 50\% of the region's exports are comprised of raw materials, whose sharp price declines led to falling incomes and demand. There is now fresh evidence of recovery in industrial production and sales activity in some major steel-using industries, supported by aggressive fiscal and monetary policies. As a result, demand for steel appears to have gradually recovered in some markets in recent months. Steel production, which was cut by nearly $50 \%$ at the end of 2008 , has recovered during the course of 2009 , reaching monthly levels just slightly below those observed prior to the market downturn last autumn. Market conditions tend to vary across countries, however.

In Brazil, the key steel producer in South America (accounting for $70 \%$ of production, $76 \%$ of exports, and $56 \%$ of consumption) an easing of taxes, improved financial conditions, and government infrastructure spending have helped boost domestic automotive sales, appliances, and have supported a gradual recovery in construction. As a result, steel consumption, which had contracted by $36 \%$ in the first quarter of 2009 from the previous quarter, has since recovered. In the third quarter, consumption increased at a quarterly rate of $14 \%$ to 3.8 million tonnes, according to CRU data, though this is still down by $28 \%$ compared to one year earlier. Brazilian steel production has recovered to monthly levels of slightly less than three million tonnes in September and October 2009, near levels seen through much of 2008.

Conditions in Argentina, the second largest producer and consumer in the region, are not as favourable, with the economy still in deep recession and in high inflation mode. Any recovery in industrial production will be weak and quite lagged, and apparent consumption of steel is contracting sharply. Steel production in the first ten months of 2009 was down $34 \%$ from a year earlier.

Venezuela, where steel consumption had been increasing steadily from a low level in recent years, on the strength of the oil and gas sector, has experienced a severe terms-of-trade shock, resulting in weakening private consumption and private investment. High inflation, tight credit and concerns over asset appropriations will probably keep steel consumption linked to consumer spending and private investment very weak in the near term, though the oil sector could recover in line with higher oil prices.

Following an overall contraction in apparent steel consumption of $24.7 \%$ in 2009, forecast by the World Steel Association, consumption will recover in 2010 in the wake of improved economic growth and recovery in steel-using sectors. Over the longer term, prospects for South American steel consumption prospects are favourable, owing to a young and growing workforce, rising incomes, and the potential for growth in per capita steel consumption levels from their current relatively low levels.

South America is a net exporter of steel products. Steelmaking capacity is typically higher than regional demand, but the gap has narrowed in recent years. Brazil has attracted large investments by both domestic and foreign steelmakers, underpinned by comparative advantages such as energy and raw material availability, low labour costs and favourable steel demand. Though some new steel mill projects were postponed or cancelled due to the financial crisis and the slumping steel market, steel producers are beginning to resume their projects. Good access to the region's rich raw material resources and the promising longer-term market outlook are supporting this development. Steelmaking capacity is projected to increase steadily from 64.4 million tonnes in 2009 to 76.5 million tonnes in 2012. 
The economic contraction seen in North Africa and the Middle East this year has been more moderate than that of most other regions. Nevertheless, a slumping real estate market, falling oil revenues, and a sharp drop in exports are contributing to falling GDP as well as deficits in the current account and fiscal positions of some countries in the region. Apparent consumption of steel has declined relatively little, however, supported by demand in the Iranian construction sector linked to ongoing projects in the oil, gas and petrochemical sectors. Iran is the biggest consumer of steel in the region, with a share of around $30 \%$. In Egypt, the second largest consumer in the region, steel demand has expanded, supported by a government national housing plan for youth. On the other hand, Saudi Arabia and the United Arab Emirates are seeing consumption of steel contract owing to delays and cancellations of projects in the real estate market.

Reflecting the better demand situation, crude steel production in the Middle East through most of 2009 is up slightly on 2008 levels, especially in Iran where capacity is estimated to have increased by 5 million tonnes to 17 million tonnes in 2009. Elsewhere production is down on 2008 levels, with imports up in the first half of the year to meet domestic demand.

Steelmaking capacity is much lower than apparent steel consumption in the Middle East, and this negative gap has widened in recent years because of soaring demand. Many steelmakers have planned to build direct reduced iron-based based mini-mills in order to meet expectations of strong demand. In Iran, the government is leading the capacity expansion with an aim to alleviate the shortage of steel products. Steelmaking capacity is projected to increase substantially from 31 million tonnes in 2009 to 50 million tonnes in 2012 as many of the expansion projects are continued or resumed in spite of the financial crisis.

As for Africa, crude steel production has typically been much lower than demand because some major steel facilities were closed. Now some plants are being revived mainly in Central Africa, aided by infrastructure instalments that facilitate production. Steel demand is increasing gradually and many foreign companies are planning to invest in mining projects thanks to the region's abundant natural resources. In North Africa, steel demand and steelmaking capacity have increased in response to favourable economic developments and construction activity. In South Africa, steel demand has increased, with capacity lagging this development somewhat. As a whole, African steelmaking capacity is projected to increase from 31 million tonnes in 2009 to 37 million tonnes in 2012.

\section{Oceania}

In recent years, steel demand has increased steadily from a comparatively low level in Oceania, on favourable economic conditions themselves the result of buoyant raw material market conditions. The global slowdown, however, led to falling agricultural and other commodity prices, which depressed investment in mining and agriculture, two important industries in the Australian and New Zealand economies. After experiencing significant slowdowns, these economies are now on their way to recovery.

In Australia, steel mill expansion projects have not been developed, despite the fact that the country is the world's largest exporter of iron ore and coking coal and many mining investments are taking place. As a result, steelmaking capacity is projected to remain unchanged until 2012. 


\section{Steelmaking Raw Materials}

Following several years of growing demand, tight supplies, and record price increases, steelmaking raw material markets weakened considerably in the last quarter of 2008 and first quarter of 2009 as a consequence of the sharp downturn in world steel production. Negotiations between miners and steel mills for contracts in the 2009 fiscal year resulted in considerably lower prices of iron ore and coking coal, though at higher levels than in 2007. However, with steel production increasing in China and other developing countries, raw material spot prices have shown a slight recovery since the second quarter of 2009.

\section{Iron ore}

World iron ore production grew by $11.5 \%$ in 2007 and $3.6 \%$ in 2008, raising the volume mined to 1.72 billion tonnes last year (Figure 11). Most of the growth occurred in the four main producing countries, i.e., Australia, Brazil, China and India. Production growth over the last few years has been especially rapid in China, which has become the largest iron ore producer in the world. Due to the low ferrous content of its ore and large steel production, however, Chinese imports have also increased rapidly. In 2003, China surpassed Japan to be the world's largest importer of iron ore, and in 2008 it already accounted for $49 \%$ of the world's imports.

At the end of 2008, iron ore producers began to cut production significantly in response to the demand slowdown. As a result, iron ore production in the first half of 2009 decreased by $9.5 \%$ to 787 million tonnes, according to data provided by the United Nations Conference on Trade and Development (UNCTAD). The main producers have now started to raise iron ore production, however, to meet demand from steel producers in China and other developing countries. For example, Rio Tinto, the second largest iron ore supplier in the world, raised its 2009 forecast for iron ore output to 210-215 million tonnes. This came after the company reported a $12 \%$ leap in third-quarter output to a record 47.5 million tonnes (compared to 42.4 million tonnes a year earlier).

Figure 11: Global iron ore production

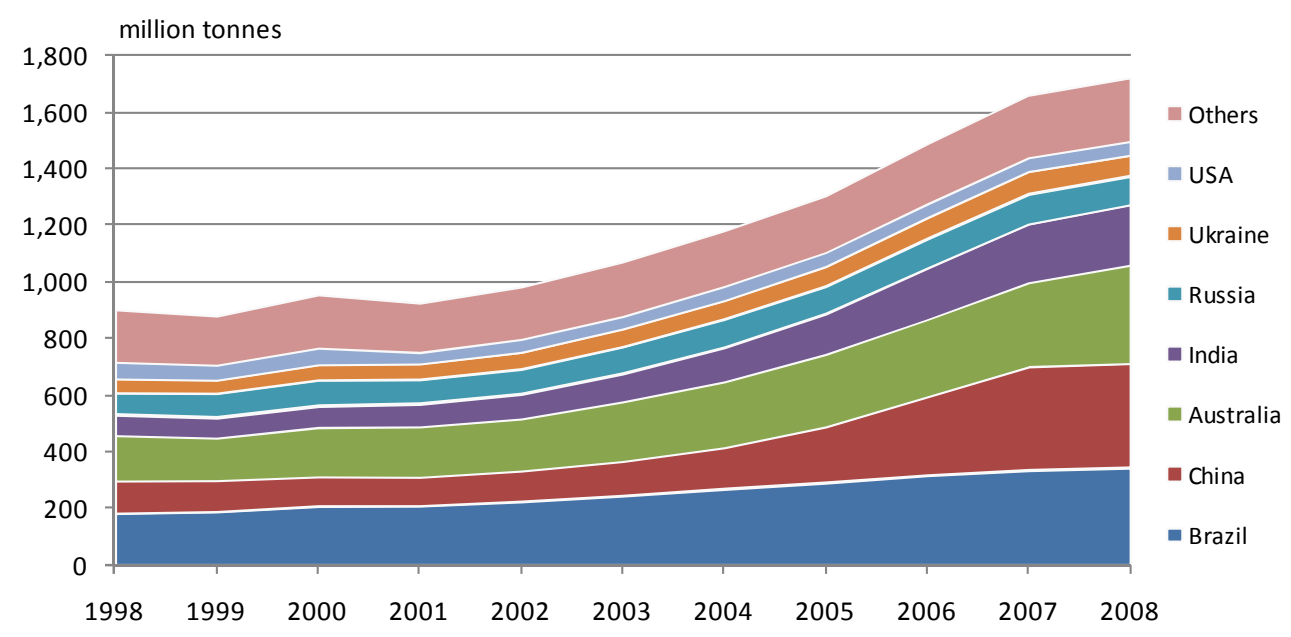

Source: UNCTAD. 
Iron ore trade reached new highs in 2008, with world exports expanding by $8 \%$ to 889 million tonnes, despite the slowdown at the end of the year. Australia increased its exports by $15.9 \%$ to 309 million tonnes. Exports from Brazil grew by $4.6 \%$ to 282 million tonnes, despite the $15 \%$ year-on-year decline in the fourth quarter. Indian exports are destined primarily to the Chinese market, where strong growth in steel production has led to significant export gains for India in recent years. Last year, Indian exports climbed to 101 million tonnes. As part of its stimulus package, the Indian government eliminated the export duty on iron ore fines in early December 2008 (after having lowered the tax to 8\% in November) and reduced the duty on lump ore to $5 \%$ from $15 \%$. The three largest exporters - Australia, Brazil and India - accounted for $78 \%$ of total world exports in 2008, up from 69\% in 1998.

China's importance as an iron ore importer has grown despite strong growth in domestic production. According to UNCTAD, China's iron ore imports surged by $29 \%$ in the first half of 2009 , while other major steel-producing countries recorded substantial reductions in imports. There have been concerns amongst steel producers that Chinese imports are being driven by stockpiling by speculators and traders, and the China Iron and Steel Association (CISA) has asked the government to revoke import licences in order to better control the volumes of overseas iron ore entering the country.

\section{Figure 12: Global iron ore trade}
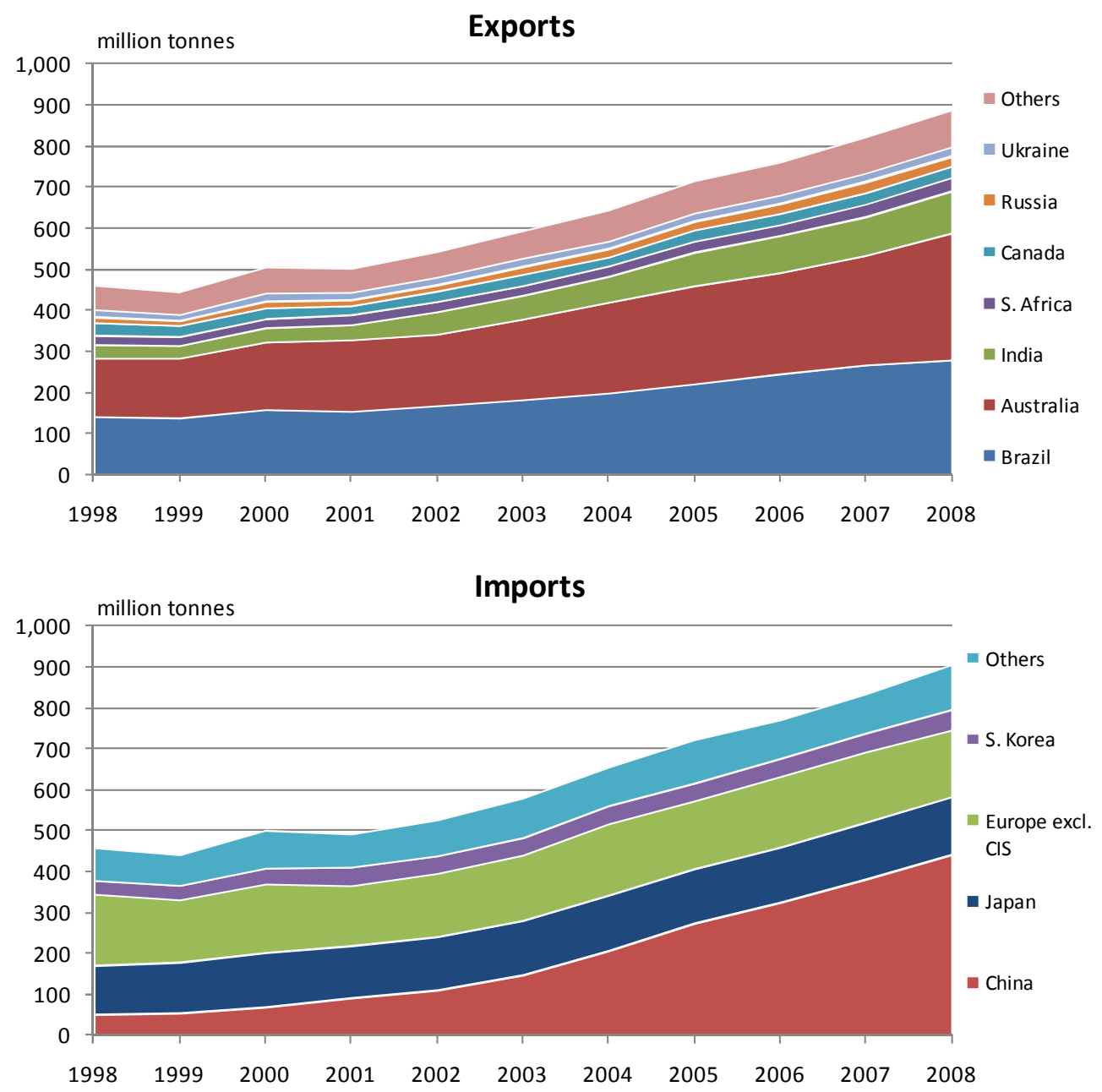

Source: UNCTAD. 
Iron ore production capacity has increased strongly in recent years, as major iron ore producers re-invested profits into mine development. UNCTAD reports that new iron ore mining capacity taken into operation in 2008 reached around 90 million tonnes in 2008, lower than the 130 million-tonne increase observed in 2007. While a lower number of projects will be announced over the coming few years, UNCTAD notes that there are still a number of projects in the pipeline. For example, Brazil's Vale, the largest producer, is planning to spend a total of some USD 16.6 billion over the coming years on various iron ore expansions. The company, which acquired the Australian coal producer AMCI Holdings in 2007, also has some coal projects, and thus will be able to compete with Rio Tinto and BHP Billiton to supply both major steelmaking inputs. BHP Billiton is also investing heavily to expand its iron ore operations in Western Australia. Fortescue, an emerging mining force in Australia after Rio Tinto and BHP Billiton, is also looking to ramp up capacity from its current level of 55 million tonnes per annum to possibly 155 million tonnes over the longer term.

Concentration in the iron ore sector declined slightly in 2008, owing particularly to significant production cuts at the end of the year by Vale and Rio Tinto to support prices (Table 1). Over the past few years, the faster growth of smaller producers, especially in India and China, have led to a gradual decline in the industry's concentration, with the production share of the big three falling from slightly more than $36 \%$ in 2003-2005 to 34\% in 2008. The market share of the ten largest producers declined below $50 \%$ in 2008 for the first time since the early 2000s. Nevertheless, the big three continued to account for approximately $70 \%$ of global seaborne trade in 2008 (Figure 13). BHP Billiton's decision not to acquire Rio Tinto, due to concerns of plunging commodity prices and the global recession, and the discontinued merger talks between Vale and Xstrata have also prevented what might have otherwise been a considerable rise in industry concentration. Meanwhile, in June 2009, Rio Tinto and BHP Billiton announced a plan to merge their Australian iron ore operations, in a joint venture valued at the time at $\$ 116$ billion.

Table 1: Concentration of the iron ore mining industry

\begin{tabular}{llcc}
\hline \multicolumn{1}{c}{ Company } & Economy & $\begin{array}{c}\text { Production } \\
\text { (million } \mathrm{mt})\end{array}$ & $\begin{array}{c}\text { Share of Total Global } \\
\text { Production (\%) }\end{array}$ \\
\hline Vale & Brazil & 303.0 & 17.6 \\
Rio Tinto & UK & 150.0 & 8.7 \\
BHP Billiton & Australia & 137.0 & 7.9 \\
SAIL \& NMDC & India & 54.0 & 3.1 \\
ArcelorMittal & Luxembourg & 46.0 & 2.7 \\
Metalloinvest & Russia & 38.0 & 2.2 \\
Anglo American & Africa & 36.7 & 2.1 \\
Cliffs Natural Resources & USA & 32.7 & 1.9 \\
System Capital Mgmt & Ukraine & 24.5 & 1.4 \\
LKAB & Sweden & 23.9 & 1.4 \\
Total, 10 largest & & 846.0 & 49.0 \\
World total & & 1725.0 & 100.0 \\
\hline
\end{tabular}

Source: Raw Materials Group.

The downturn in steel production rapidly fed through to lower demand and prices of iron ore at the end of 2008. Spot prices of iron ore began falling sharply in September 2008, and by December had reached USD 60 per tonne (for $63.5 \% \mathrm{Fe}$ content) from levels near USD 150 during the beginning of the year (Figure 14). Contract iron ore prices declined by $28 \%$ for the 2009 fiscal year, following six consecutive years of price increases which led to an almost five-fold increase in the Brazilian price of iron ore fines during 2003-2008. Contract negotiations between Australian miners and Asian steel mills led to a deeper, $33 \%$ price cut for iron ore fines in the 2009 fiscal year, following a record $79.9 \%$ price rise last year. In 
2008, Australian miners had successfully negotiated a larger increase in price because of the freight advantages of shipping ore from Australia to Asia compared with Brazil to Asia.

The iron ore spot market has recovered somewhat since the second quarter of 2009, in line with the expansion of Chinese steel production. After falling to USD 53 per tonne in April, spot prices increased to USD 85 per tonne in August 2009. Reflecting these developments, the China Iron and Steel Association (CISA) expects a 10\% increase in the iron ore contract price for the 2010 fiscal year.

Figure 13: Share of seaborne iron ore trade

1980 (Total 314Mt)

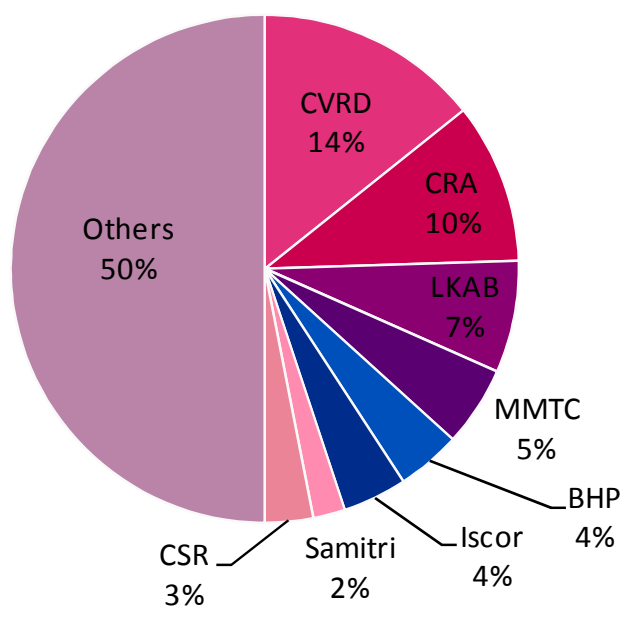

Sources: Mitsui \& Co Ltd and Raw Materials Group.

\section{8 (Total 805Mt)}

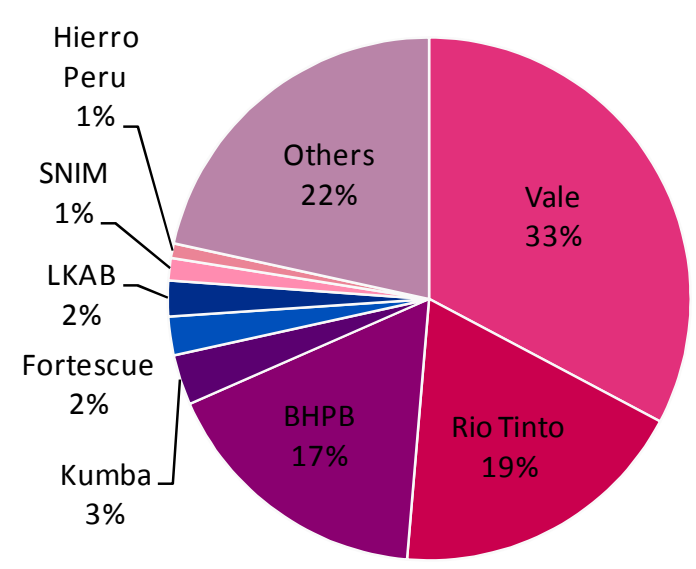

Figure 14: Iron ore prices
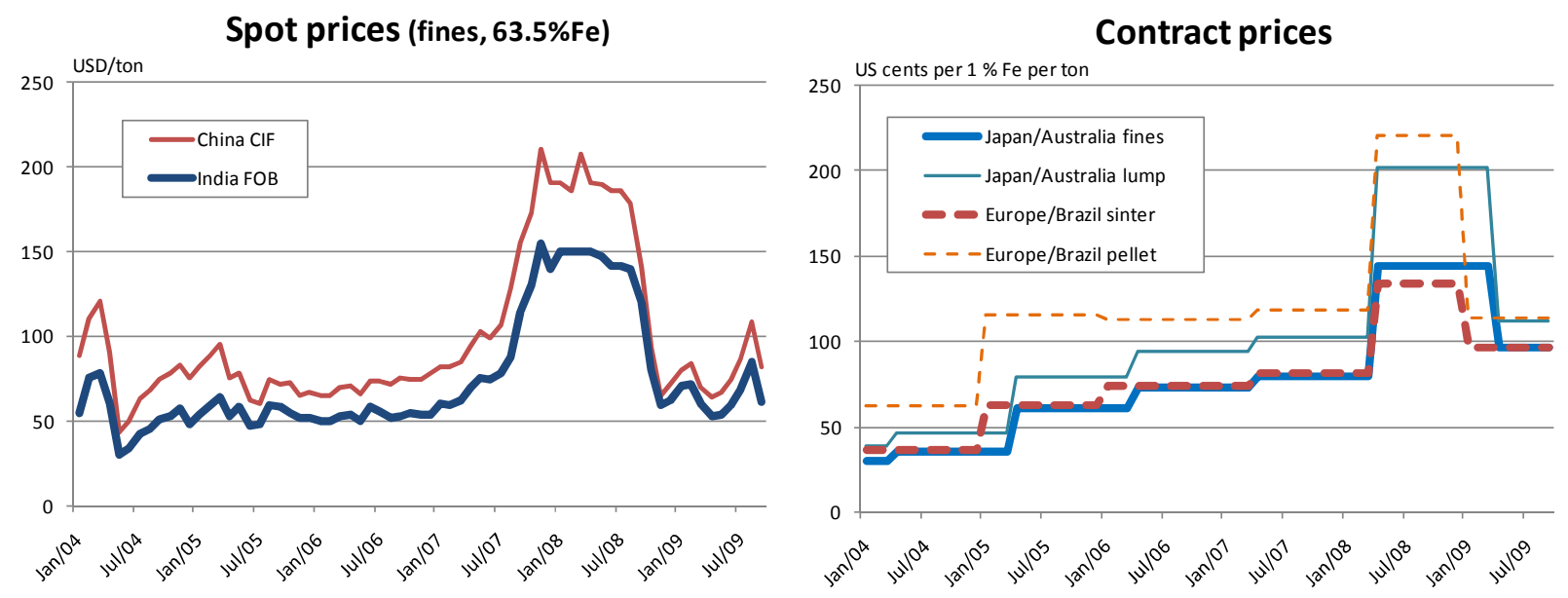

Sources: Commodity Research Unit and Steel Business Briefing. 
Ferrous scrap demand was hit hard during the recent downturn. After rising sharply in the first seven months of 2008 to all-time highs, scrap prices began plunging in August (Figure 15). The composite price in the United States (No. 1 heavy melt), the world's largest scrap supplier, fell below USD 100 per gross ton in mid-November, down from more than USD 500 in the summer months and USD 330 at the beginning of the year. This came after a gradual upward trend in scrap prices during 2002-2007, on the back of strengthening world steel production and lower supplies by traditional exporters as their electricarc furnace steel production capacity increased. Scrap prices now appear to be recovering, climbing to above USD 250 per tonne in September, reflecting improved steel market conditions.

Figure 15: Scrap composite prices in the U.S. (No. 1 heavy melt)

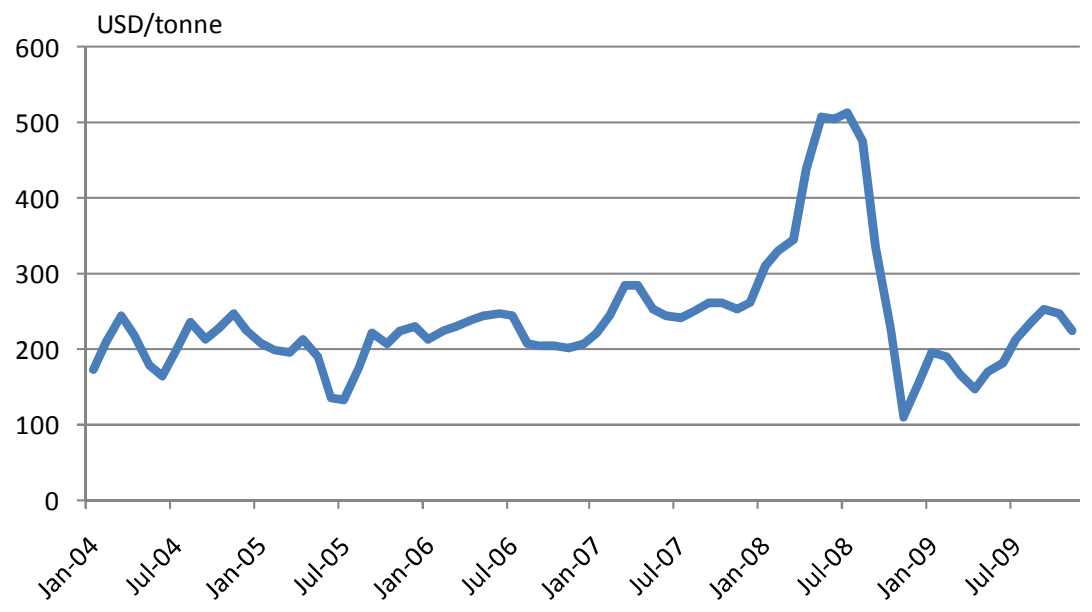

Source: American Metal Market.

Scrap prices tend to be very sensitive to demand shifts in Turkey, the world's largest importer of scrap due its high share of scrap-intensive electric arc furnaces in steel production. Turkish demand for scrap declined sharply in the last quarter of 2008 following strong import growth in the second and third quarters of the year. For 2008 as a whole, Turkish imports of scrap remained roughly unchanged at the previous year's level, settling at slightly more than 17 million tonnes.

The United States is the largest exporter of scrap in the world, sending large volumes of the material to Turkey and China. U.S. scrap exports for 2008 as a whole rose to 21.7 million tonnes, up more than $30 \%$ from 2007. However, this masks a very sharp decline towards the end of 2008 as global steel production began to contract. U.S. exports of scrap have recovered during 2009, reaching monthly levels above two million tonnes in May, June, and August as low prices encourage some buying activity and steel production, particularly in China, increases.

EU exports also showed significant declines at the end of 2008. Although a significant importer of scrap, the European Union is a major net exporter, with Turkey being its biggest export market. In 2008, EU exports increased by $18 \%$ to 13 million tonnes, supported by strong growth in shipments to Turkey and smaller markets such as India, Egypt and Chinese Taipei during the first three quarters of the year. After declining by $8 \%$ to 5.4 million tonnes in 2008, import activity in the EU remained weak during 2009, especially in the large import markets of Italy and Spain due to low steel production in response to weak construction activity. 
Russia used to be a large scrap exporter, sending approximately the same amount of scrap abroad as the United States in 2004-2005 (13 million tonnes per annum). Since 2006, however, Russia's export volumes have declined steadily, partly due to growing domestic demand as scrap-intensive electric arc furnace production increases. Exports fell further in 2008, reaching only 5.1 million tonnes from 7.9 million tonnes in 2007. The Russian government imposes some restrictions on scrap exports, such as an export duty of $15 \%$ or EUR 15 per tonne, whichever is larger. In January to June 2009, Russian exports were down by $91 \%$ year-on-year to only 0.3 million tonnes.

Japan, a major scrap supplier to South Korea, China and Chinese Taipei, recorded a drop in scrap exports to 5.3 million tonnes in 2008, from 6.4 million tonnes in 2007. However, Japanese exports rebounded in the first half of 2009, driven by increases in shipments to China and recovering demand in South Korea and Chinese Taipei. Figures for the first nine months of 2009 show that China became the largest importer of scrap ahead of Turkey. In fact, Chinese imports through September increased by nearly $400 \%$ from the corresponding period of 2008 to more than 11 million tonnes.

Southeast Asia is becoming increasingly important as an importer of scrap. This is due to the region's steel production being dominated by electric-arc furnaces and relatively low domestic scrap collection. In ASEAN, where all steelmakers operate electric-arc furnace facilities, net imports reached 6 million tonnes in 2007, according to the South East Asia Iron and Steel Institute. In 2008, imports rose by $13 \%$ to 9 million tonnes, while exports fell modestly to 2.1 million tonnes.

Figure 16: Global scrap consumption

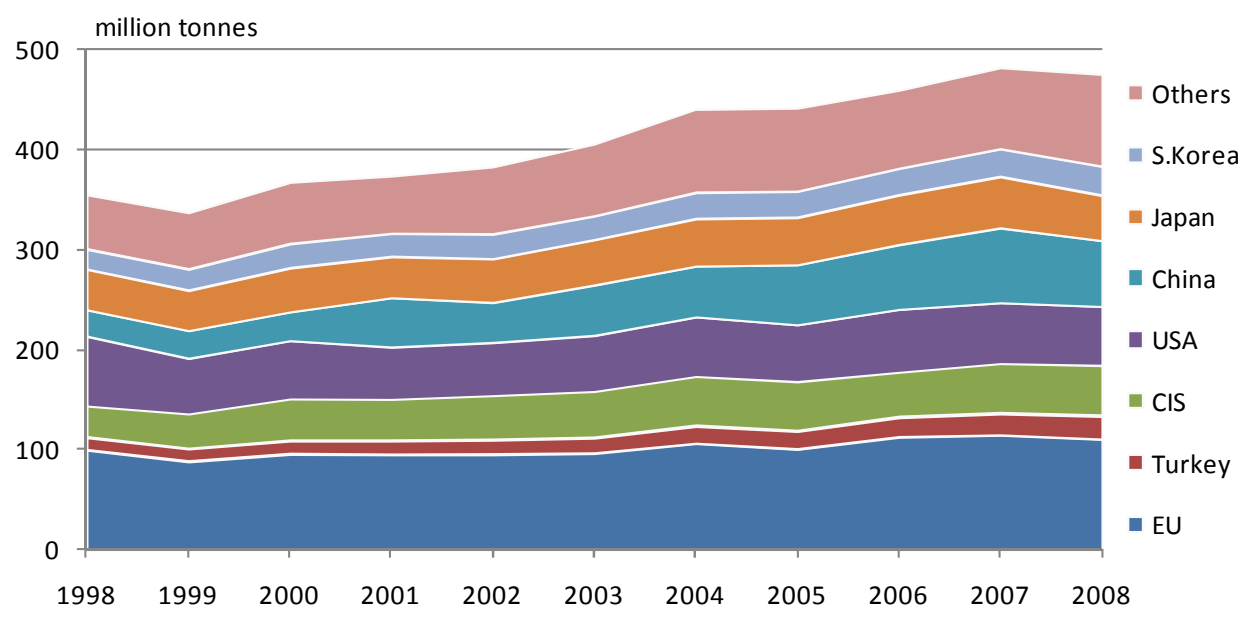

Source: World Steel Association. 
Figure 17: Trade in ferrous scrap during 2000-2008
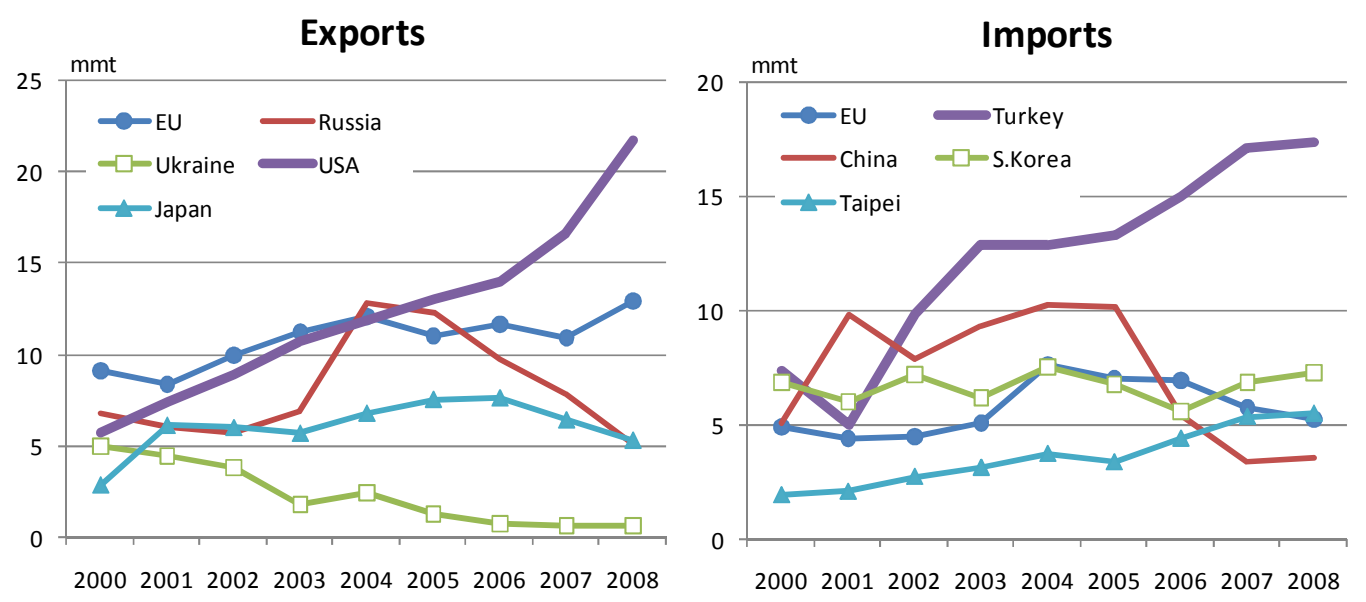

Sources: World Steel Association and UN Comtrade.

\section{Coking coal and coke}

World coking coal production has increased rapidly in recent years, supported by rising steel production (Figure 18). In 2008, production amounted to 854 million tonnes, up 11\% from 2007. Most of the growth occurred in China, which now accounts for half of global production in 2008. World metallurgical coal trade has also expanded in recent years. According to figures released recently by the International Energy Agency, global exports increased by $9.6 \%$ to 262 million tonnes in 2008 despite the slowdown at the end of the year. Exports from Australia, the largest exporter in the world with a market share of more than half, grew by only $4 \%$ to 137 million tonnes, restrained by some supply problems due to flood-related mine closures, port congestion and a shortage of rail capacity. In light of still strong demand for coking coal in the first part of 2008, other coking coal exporters compensated for Australia's supply problems by raising their overseas shipments significantly. For example, U.S. and Russian exports increased respectively by $32 \%$ and $55 \%$ in 2008 . The U.S. is the second largest exporter with a market share of $15 \%$, followed by Indonesia (11\%), Canada (10\%), and Russia (6\%).

Figure 18: Global coking coal production

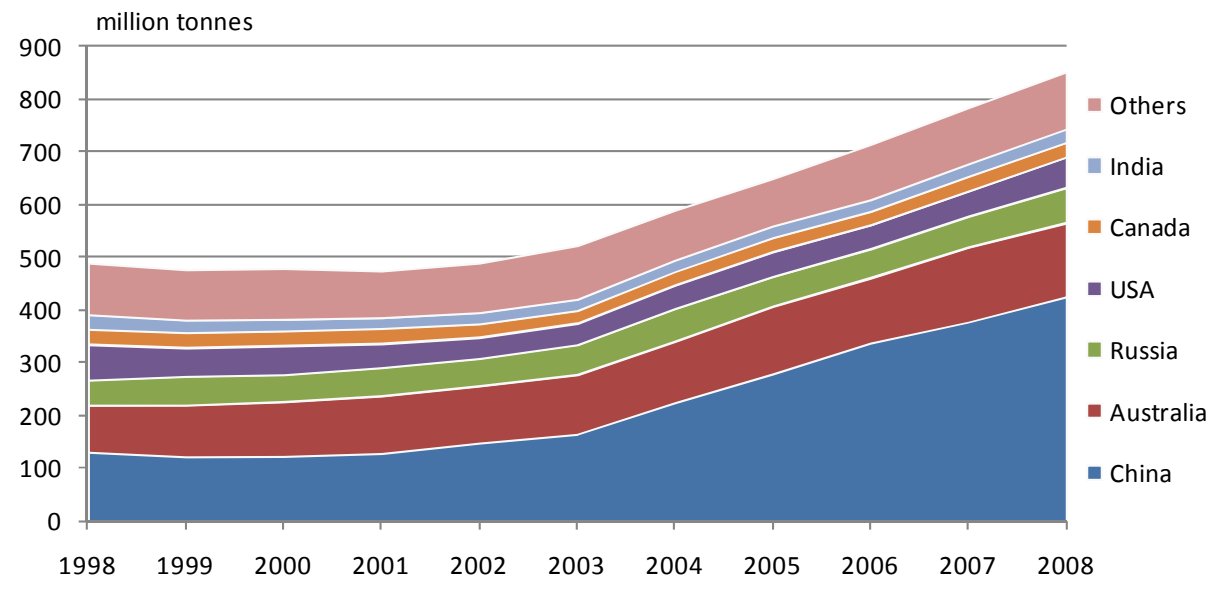

Source: IEA. 
At the end of 2008, demand for coking coal began to contract sharply in line with large steel mill production cuts, generating considerable oversupply in the market. Widespread customer deferrals of coking coal shipments, together with still positive supply side developments, led to large increases of material on spot markets and falling prices. By December, the spot price of Australian hard coking coal had fallen to USD 150 per tonne, down from a peak of USD 400 in July 2008. The price fell further during 2009, reaching USD 115 in July 2009. Reflecting the market downturn, the contract price also declined significantly. In March, Nippon Steel and BHP Billiton Mitsubishi Alliance settled on a contract price for coking coal at USD 128 to USD 129 per tonne for the 2009-10 fiscal year. This represents approximately a $57 \%$ decline from last year's contract price of USD 300. Since last summer, however, coking coal demand and prices have recovered slightly due to rebounding global steel production (Figure 19). In September 2009, the spot price rose to USD 170 tonnes and metallurgical coal exports from Australia reached 13.9 million tonnes, after falling to 7 million tonnes in February.

India has become a growing importer of metallurgical coal, with import volumes reaching 28.8 million tonnes in 2008 from 10 million tonnes in 1998 (Figure 20). Japan and Europe, traditionally large importers, have not seen imports change so much. China, the world biggest coal producer, has increased imports of metallurgical coal substantially because of rising pig iron production and domestic coal supply constraints. According to the Commodity Research Unit, in the third quarter of 2009, Chinese imports amounted to 13 million tonnes up from 2.3 million tonnes a year ago.

Figure 19: Coking coal prices

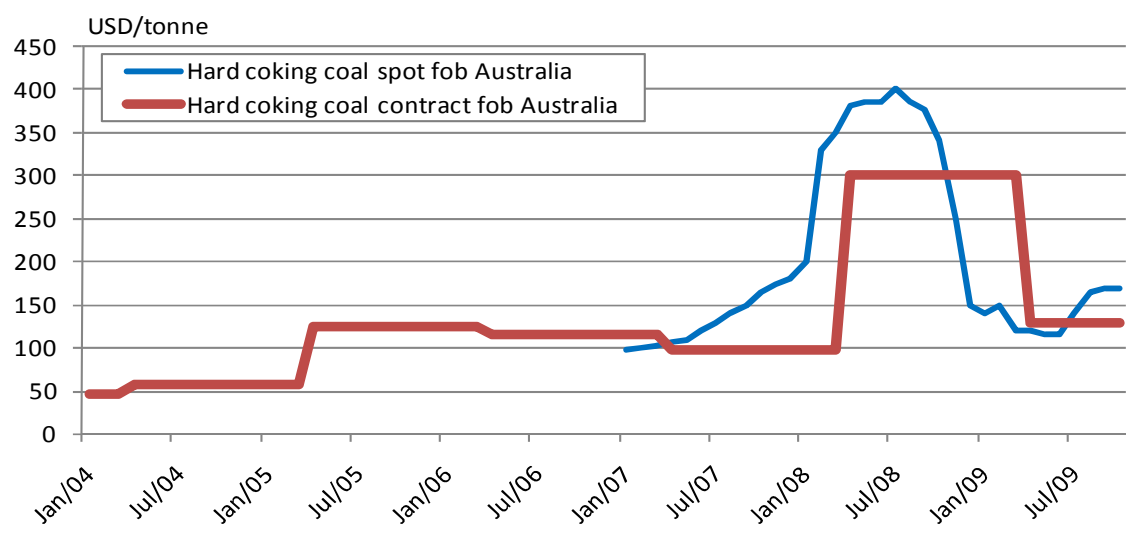

Source: CRU

World coke production has become increasingly concentrated in Asia, particularly in China, over the past decade (Figure 21). According to Resource-Net, Asian coke production increased to approximately 390 million tonnes in 2007 from 200 million tonnes in 1997. The CIS region has also seen some increases in coke production, with growth of $30 \%$ over the past ten years. In contrast, European and NAFTA coke production has fallen by $17 \%$ and $23 \%$, respectively, over the same period.

The first half of 2008 was characterised by sharp rises in coke prices. The steel production downturn in the second half of 2008, together with rising coke inventories, caused many mills to cancel or delay coke purchases. The stock overhang was particularly acute in India, where mills had purchased large quantities of coke earlier in the year at high prices and therefore stayed out of the market in the latter part of 2008. Demand in large importing economies - the United States, Europe and Japan - also contracted sharply as steel production cuts took hold. As a result of the demand downturn, the Chinese export price of coke fell to USD 330 at the end of 2008, declining further to USD 200-220 in February to April of 2009. With domestic steel production down sharply, Japanese coke producers have also offered material for export at 
sharply lower prices. Like other steelmaking raw materials, however, coke price have started to rise in recent months owing to the nascent recovery in global steel production (Figure 22).

Figure 20: Global coking coal trade
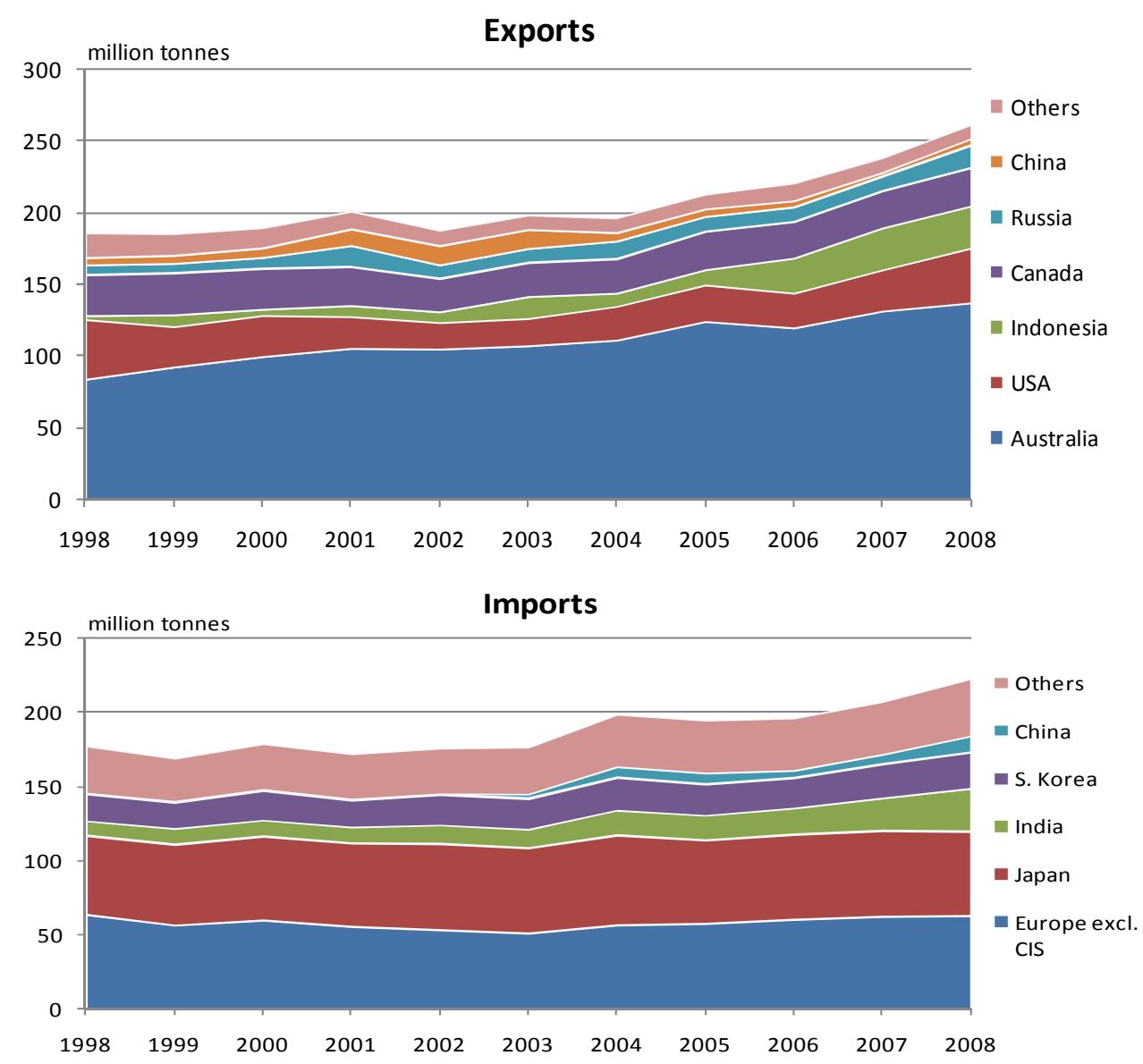

Source: IEA

Figure 21: Global coke production

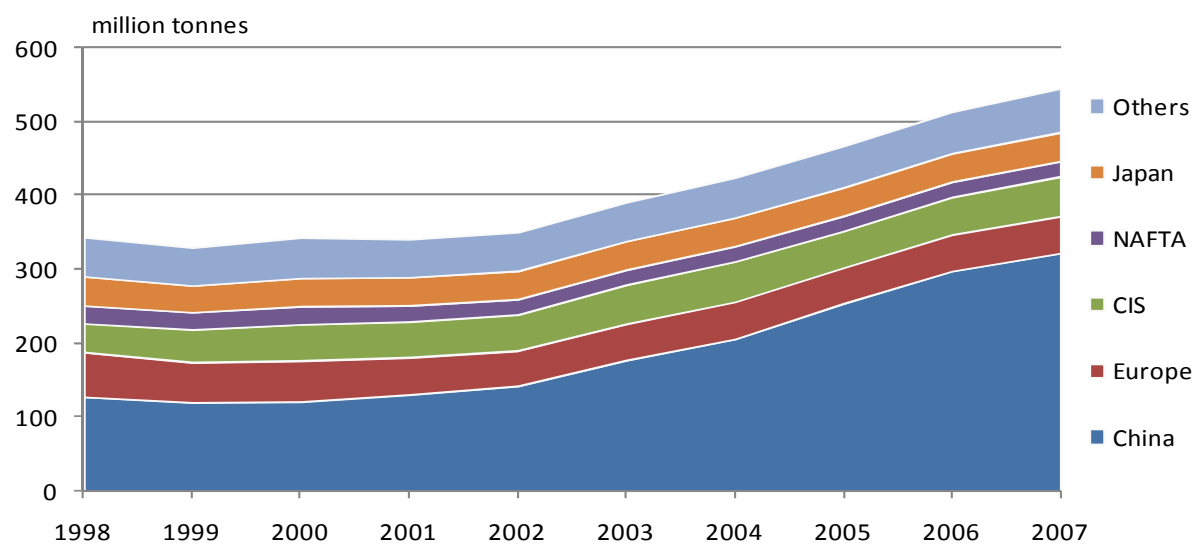

Source: Resource-Net. 
Figure 22: Chinese coke export prices (12.5\% ash)

Source: $C R U$

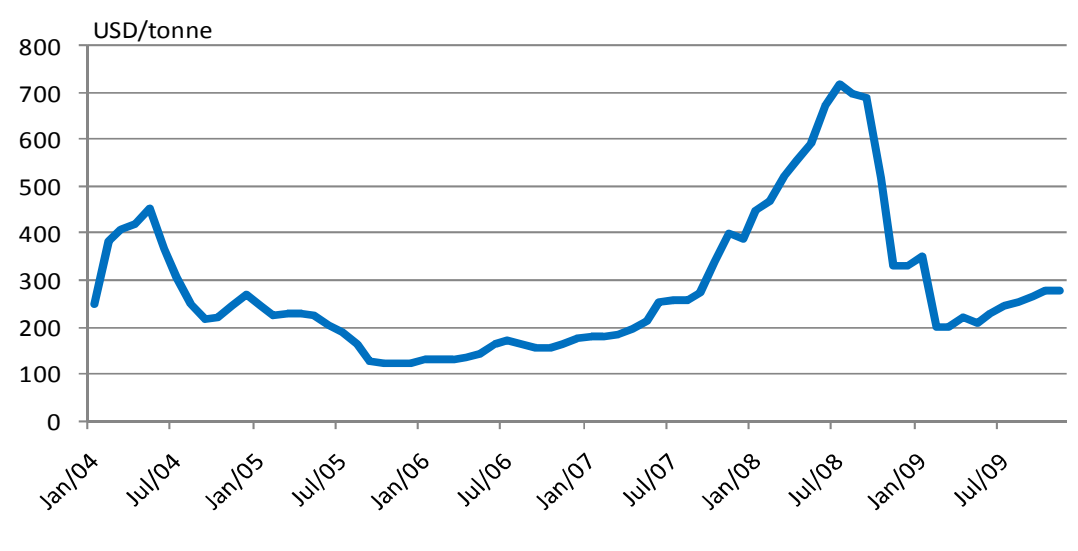

In addition to the market downturn, government policies have also discouraged coke trade via taxes and export licence systems. A tightening of supply is expected to come from the significant reduction in coke export licenses issued by the Chinese authorities in the beginning of 2009 and the export tax on Chinese coke which has not been lowered yet from its current level of $40 \%$. Chinese coke exports declined by $21 \%$ to 12 million tonnes in 2008 and in the first nine months of 2009 stood at just 0.4 million tonnes, representing a $96 \%$ contraction year-on-year.

In the global coke market, China is the biggest exporter followed by Poland (Figure 23). Europe accounts for around $40 \%$ of the world's imports. The United States, Brazil, Ukraine, Japan and India are also major importers.

Figure 23: Trade in coke during 2000-2008
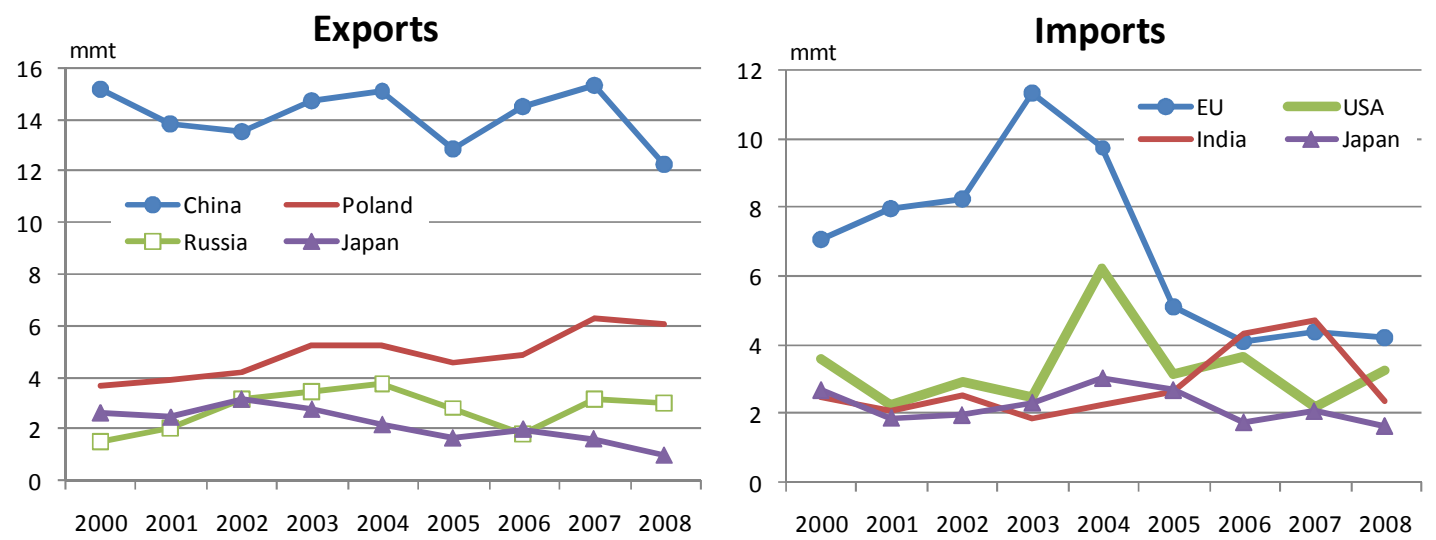

Sources: IEA and UN Comtrade. 


\section{ANNEX 1}

\section{STATISTICAL APPENDIX/ANNEXE STATISTIQUE}

Table 1. World pig iron production

Tableau 1. Production mondiale de fonte (Million tonnes)

Table 2. World crude steel production

Tableau 2. Production mondiale d'acier brut (Million tonnes)

Table 3. World continuously-cast steel output

Tableau 3. Production mondiale d'acier en coulée continue (Million tonnes and \%)

Table 4. World crude steel breakdown by process

Tableau 4. Production mondiale d'acier brut par procédé de fabrication (\%)

Table 5. Total employment

Tableau 5. Emploi total ('OOO)

Table 6. Total imports of steel

Tableau 6. Importations totales d'acier ('OOO T)

Table 7. Total exports of steel

Tableau 7. Exportations totales d'acier ('OOO T)

Table 8. Apparent consumption of finished steel

Tableau 8. Consommation apparente de produits finis en acier (Million tonnes)

Table 9a. World steel product prices

Tableau 9a. Prix mondiaux des produits en acier (USD/tonne)

Table 9b. World steel product price indexes (based on USD values)

Tableau 9b. Indices de prix mondiaux des produits en acier (base: valeur USD)

Table 1Oa. European Union steel product prices

Tableau 1Oa. Prix des produits en acier de 1'Union Européenne (Euro/tonne)

Table 1Ob. European Union steel product price indexes (based on Euro values)

Tableau 1Ob. Indices de prix des produits en acier de 1'Union Européenne (base : valeur Euro)

Table 11 a. North American steel product prices

Tableau 11 a. Prix des produits en acier nord-américains (USD/tonne)

Table $11 \mathrm{~b}$. North American steel product price indexes (based on USD values)

Tableau $11 \mathrm{~b}$. Indices de prix des produits en acier nord-américains (base : valeur USD)

Table 12a. Asian steel product prices

Tableau 12a. Prix des produits en acier d'Asie (USD/tonne)

Table 12b. Asian steel product price indexes (based on USD values)

Tableau 12b. Indices de prix des produits en acier d'Asie (base : valeur USD)

Table 13. Reference prices of steelmaking raw materials

Tableau 13. Prix de référence de matières premières pour la production d'acier

Table 14. World iron ore market by major economy

Tableau 14. Le marché du minerai de fer dans les principales économies du monde (Million tonnes)

Table 15. World coke market by major economy

Tableau 15. Le marché du coke dans les principales économies du monde (Million tonnes)

Table 16. World coking coal market by major economy

Tableau 16. Le marché du charbon à coke dans les principales économies du monde (Million tonnes)

Table 17. World scrap market by major economy

Tableau 17. Le marché de la ferraille dans les principales économies du monde (Million tonnes)

Table 18. Effective capacity for the production of pig iron and forecasts

Tableau 18. Capacité effective de production de fonte et prévisions (Million tonnes)

Table 19. World crude steelmaking capacity

Tableau 19. Capacité mondiale d"acier brut (Million tonnes) 
Table 1. WORLD PIG IRON PRODUCTION

Tableau 1. PRODUCTION MONDIALE DE FONTE

Unit : Million tonnes

Unités : Millions de tonnes

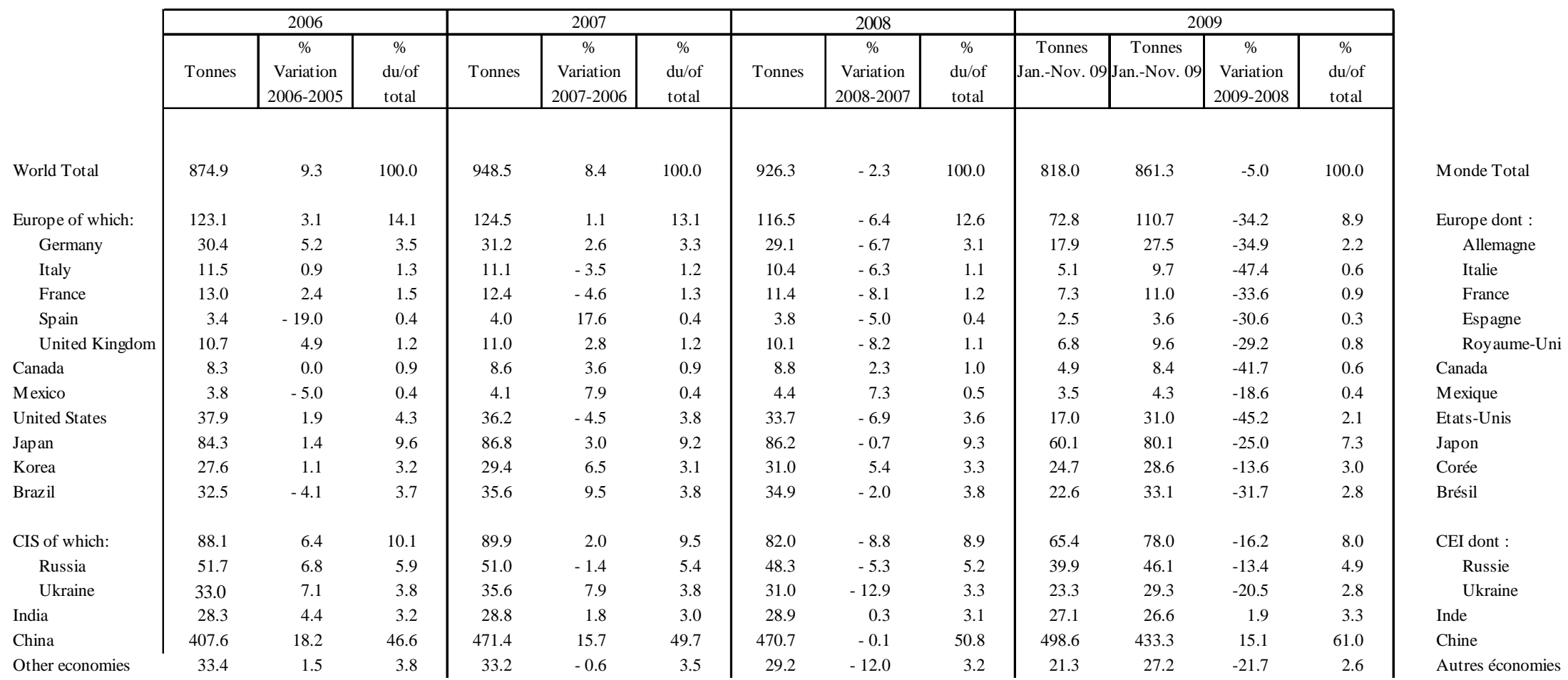

Source: World Steel Association/Association Mondiale de l'Acier 
Table 2. WORLD CRUDE STEEL PRODUCTION

Tableau 2. PRODUCTION MONDIALE D'ACIER BRUT

\begin{tabular}{|c|c|c|c|c|c|c|c|c|c|c|c|c|c|c|}
\hline & \multicolumn{3}{|c|}{2006} & \multicolumn{3}{|c|}{2007} & \multicolumn{3}{|c|}{2008} & \multicolumn{4}{|c|}{2009} & \\
\hline & Tonnes & $\begin{array}{c}\% \\
\text { Variation } \\
\text { 2006-2005 }\end{array}$ & $\begin{array}{c}\% \\
\text { du/of } \\
\text { total } \\
\end{array}$ & Tonnes & $\begin{array}{c}\% \\
\text { Variation } \\
2007-2006\end{array}$ & $\begin{array}{l}\% \\
\text { du/of } \\
\text { total } \\
\end{array}$ & Tonnes & $\begin{array}{c}\% \\
\text { Variation } \\
2008-2007\end{array}$ & $\begin{array}{c}\% \\
\text { du/of } \\
\text { total }\end{array}$ & \begin{tabular}{|c|} 
Tonnes \\
Jan.-Nov. 09
\end{tabular} & \begin{tabular}{|c|} 
Tonnes \\
Jan.-Nov. 09
\end{tabular} & $\begin{array}{c}\% \\
\text { Variation } \\
2009-2008\end{array}$ & $\begin{array}{c}\% \\
\text { du/of } \\
\text { total }\end{array}$ & \\
\hline World Total & 1251.0 & 9.1 & 100.0 & 1351.2 & 8.0 & 100.0 & 1327.2 & -1.8 & 100.0 & 1090.4 & 1222.4 & -10.8 & 100.0 & Monde Total \\
\hline Europe of which: & 235.0 & 6.6 & 18.8 & 240.1 & 2.2 & 17.8 & 229.7 & -4.3 & 17.3 & 152.4 & 218.2 & -30.2 & 14.0 & Europe dont : \\
\hline Germany & 47.2 & 6.1 & 3.8 & 48.6 & 3.0 & 3.6 & 45.8 & -5.8 & 3.5 & 29.6 & 43.4 & -31.8 & 2.7 & Allemagne \\
\hline Italy & 31.6 & 7.5 & 2.5 & 31.5 & -0.3 & 2.3 & 30.6 & -2.9 & 2.3 & 18.2 & 29.0 & -37.2 & 1.7 & Italie \\
\hline France & 19.9 & 2.1 & 1.6 & 19.3 & -3.0 & 1.4 & 17.9 & -7.3 & 1.3 & 11.7 & 17.2 & -32.0 & 1.1 & France \\
\hline Spain & 18.4 & 3.4 & 1.5 & 19.0 & 3.3 & 1.4 & 18.8 & -1.1 & 1.4 & 12.8 & 17.9 & -28.5 & 1.2 & Espagne \\
\hline United Kingdom & 13.9 & 5.3 & 1.1 & 14.3 & 2.9 & 1.1 & 13.5 & -5.6 & 1.0 & 8.9 & 13.0 & -31.5 & 0.8 & Roy aume-Uni \\
\hline Canada & 15.5 & 1.3 & 1.2 & 15.6 & 0.6 & 1.2 & 15.1 & -3.2 & 1.1 & 8.4 & 14.2 & -40.8 & 0.8 & Canada \\
\hline Mexico & 16.4 & 1.2 & 1.3 & 17.6 & 7.3 & 1.3 & 17.2 & -2.3 & 1.3 & 12.8 & 16.4 & -22.0 & 1.2 & Mexique \\
\hline United States & 98.6 & 3.9 & 7.9 & 98.2 & -0.4 & 7.3 & 91.4 & -6.9 & 6.9 & 52.6 & 87.4 & -39.8 & 4.8 & Etats-Unis \\
\hline Japan & 116.2 & 3.3 & 9.3 & 120.2 & 3.4 & 8.9 & 118.7 & -1.2 & 8.9 & 78.6 & 111.3 & -29.4 & 7.2 & Japon \\
\hline Korea & 48.5 & 1.5 & 3.9 & 51.5 & 6.2 & 3.8 & 53.5 & 3.9 & 4.0 & 44.2 & 49.9 & -11.4 & 4.1 & Corée \\
\hline Brazil & 30.9 & -2.2 & 2.5 & 33.8 & 9.4 & 2.5 & 33.7 & -0.3 & 2.5 & 23.9 & 32.1 & -25.5 & 2.2 & Brésil \\
\hline CIS of which: & 119.9 & 5.9 & 9.6 & 124.2 & 3.6 & 9.2 & 114.1 & -8.1 & 8.6 & 88.5 & 108.4 & -18.4 & 8.1 & CEI dont : \\
\hline Russia & 70.8 & 7.1 & 5.7 & 72.4 & 2.3 & 5.4 & 68.5 & -5.4 & 5.2 & 54.4 & 65.2 & -16.6 & 5.0 & Russie \\
\hline Ukraine & 40.9 & 6.0 & 3.3 & 42.8 & 4.6 & 3.2 & 37.1 & -13.3 & 2.8 & 27.0 & 35.3 & -23.5 & 2.5 & Ukraine \\
\hline India & 49.5 & 8.1 & 4.0 & 53.1 & 7.3 & 3.9 & 55.1 & 3.8 & 4.2 & 51.7 & 50.5 & 2.4 & 4.7 & Inde \\
\hline China & 423.0 & 18.9 & 33.8 & 494.9 & 17.0 & 36.6 & 500.5 & 1.1 & 37.7 & 518.2 & 462.5 & 12.0 & 47.5 & Chine \\
\hline Other economies & 97.5 & 14.3 & 7.8 & 102.0 & 4.6 & 7.5 & 98.2 & -3.7 & 7.4 & 59.1 & 71.5 & -17.3 & 5.4 & Autres économies \\
\hline
\end{tabular}

Source: World Steel Association/Association Mondiale de l'Acier 
Table 3. WORLD CONTINUOUSLY-CAST STEEL OUTPUT

Tableau 3. PRODUCTION MONDIALE D'ACIER EN COULEE CONTINUE

Unit : Million tonnes \& \%

Unités : Millions de tonnes \& \%

\begin{tabular}{|c|c|c|c|c|c|c|c|}
\hline & \multirow{2}{*}{\multicolumn{3}{|c|}{$\begin{array}{c}\text { Continuously-cast output/ } \\
\text { Production en coulée continue }\end{array}$}} & \multirow{2}{*}{\multicolumn{3}{|c|}{$\begin{array}{c}\% \text { of crude steel output/ } \\
\% \text { de production d'acier brut }\end{array}$}} & \multirow{4}{*}{ Monde Total } \\
\hline & & & & & & & \\
\hline & 2006 & 2007 & 2008 & 2006 & 2007 & 2008 & \\
\hline World Total & 1146.6 & 1239.8 & 1228.8 & 92.0 & 92.4 & 92.4 & \\
\hline Europe of which: & 197.1 & 200.9 & 190.7 & 95.2 & 95.5 & 95.5 & Europe dont : \\
\hline Germany & 45.5 & 46.7 & 44.0 & 96.3 & 96.2 & 95.9 & Allemagne \\
\hline Italy & 30.2 & 30.1 & 29.2 & 95.4 & 95.4 & 95.6 & Italie \\
\hline France & 19.0 & 18.3 & 17.0 & 95.6 & 95.1 & 94.9 & France \\
\hline Spain & 18.3 & 18.7 & 18.3 & 99.4 & 98.3 & 98.4 & Espagne \\
\hline United Kingdom & 13.7 & 14.1 & 13.3 & 98.4 & 98.5 & 98.3 & Royaume-Un \\
\hline Canada & 15.3 & 15.5 & 14.7 & 98.7 & 99.8 & 99.0 & Canada \\
\hline Mexico & 16.3 & 17.5 & 17.2 & 99.3 & 99.5 & 99.8 & Mexique \\
\hline United States & 95.3 & 94.9 & 88.6 & 96.7 & 96.7 & 96.9 & Etats-Unis \\
\hline Japan & 113.8 & 117.7 & 116.3 & 97.9 & 98.0 & 97.9 & Japon \\
\hline Korea & 47.5 & 50.4 & 52.3 & 98.0 & 97.8 & 97.5 & Corée \\
\hline Brazil & 28.5 & 31.5 & 31.8 & 92.3 & 93.3 & 94.2 & Brésil \\
\hline CIS of which: & 70.3 & 75.1 & 71.8 & 58.7 & 60.5 & 62.9 & CEI dont : \\
\hline Russia & 48.5 & 51.5 & 48.8 & 68.4 & 71.2 & 71.2 & Russie \\
\hline Ukraine & 13.7 & 14.7 & 14.6 & 33.5 & 34.3 & 39.3 & Ukraine \\
\hline India & 34.5 & 37.1 & 38.5 & 69.7 & 69.8 & 69.8 & Inde \\
\hline China & 408.0 & 474.3 & 485.5 & 96.5 & 95.8 & 97.0 & Chine \\
\hline Other economies & 120.0 & 124.9 & 121.4 & 100.0 & 100.0 & 100.0 & Autres économies \\
\hline
\end{tabular}

Source: World Steel Association/Association Mondiale de l'Acier 
Table 4. WORLD CRUDE STEEL OUTPUT BREAKDOWN BY PROCESS

Tableau 4. PRODUCTION MONDIALE D'ACIER BRUT PAR PROCEDE DE FABRICATION

Unit : Percentage

Unité : Pourcentage

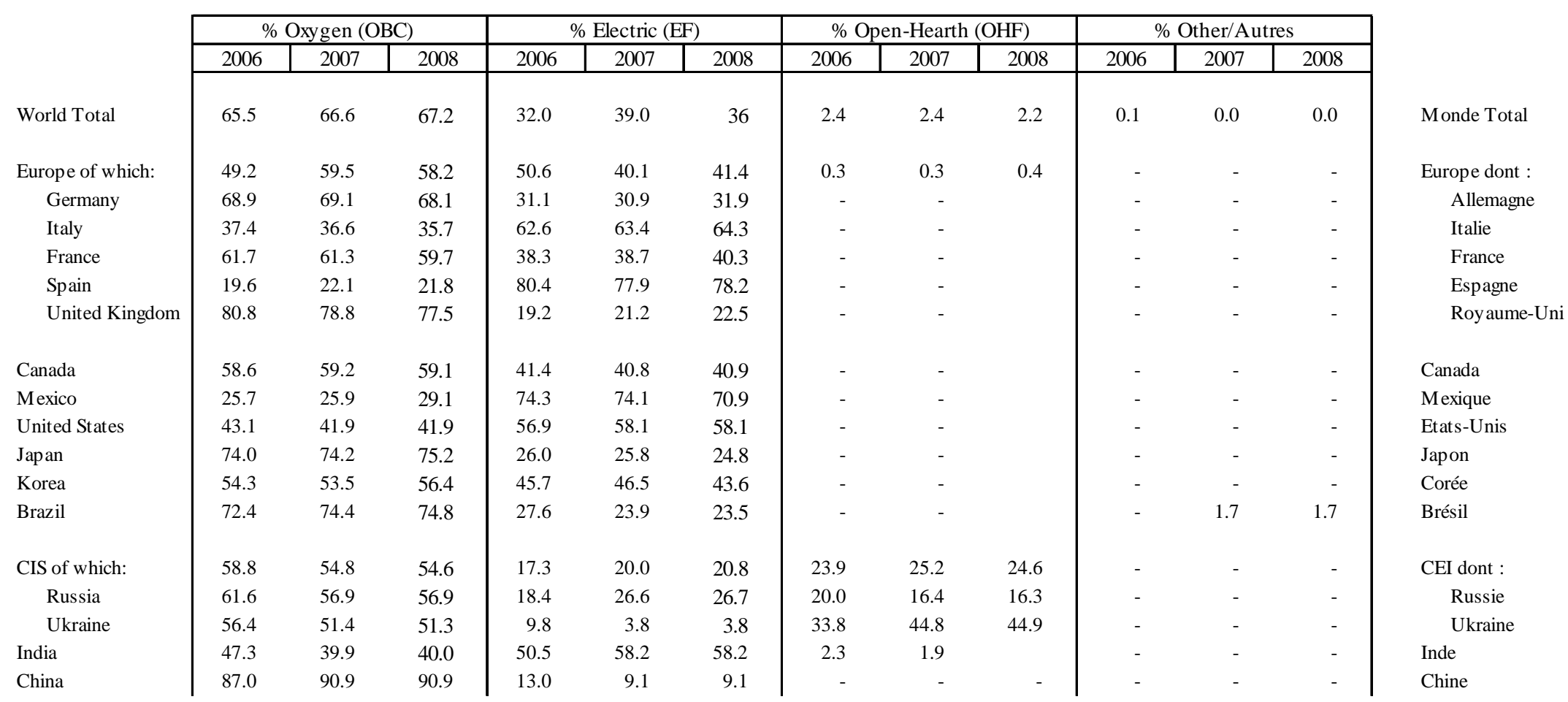

OBC: Oxy gen blown converter/convertisseur à oxy gène - EF: Electric furnace/Four électrique - OHF: Open hearth furnace/Foyer ouvert de four.

Source: World Steel Association/Association Mondiale de l'Acier 
Table 5 . TOTAL EMPLOYMENT

Tableau 5 . EMPLOI TOTAL

Unit: Thousands

\begin{tabular}{l} 
Europe of which: \\
EU(27) \\
Austria \\
Belgium \\
Germany \\
Italy \\
France \\
Spain \\
Sweden \\
United Kingdom \\
Poland \\
Czech Republic \\
Slovak Republic \\
Romania \\
Turkey \\
Canada \\
Mexico \\
United States \\
Japan \\
Korea \\
Brazil \\
Russia \\
Ukraine \\
India \\
Argentina \\
Chinese Taïpei \\
China \\
\hline
\end{tabular}

e: estimates/estimations
Unité: Miliers

\begin{tabular}{|c|c|c|c|c|}
\hline 2005 & 2006 & 2007 & 2008 & $2009 \mathrm{e}$ \\
\hline 412.0 & 404.0 & 399.0 & 397.0 & 395.0 \\
\hline 13.3 & 14.2 & 14.6 & 14.5 & .. \\
\hline 17.0 & 17.2 & 17.2 & 17.0 & 15.1 \\
\hline 91.3 & 91.1 & 92.4 & 95.4 & .. \\
\hline 38.9 & 39.0 &.. & .. & .. \\
\hline 34.3 & 33.2 & 33.2 & 33.2 & .. \\
\hline.. &.. &.. & .. & .. \\
\hline .. & .. & .. & .. & .. \\
\hline 18.7 & 18.4 & 18.6 & 18.4 & 17.6 \\
\hline 28.8 & .. & .. &.. & .. \\
\hline 25.0 & 24.0 & 22.4 & 22.0 & .. \\
\hline 17.4 & 16.8 & 16.6 & .. & .. \\
\hline 43.8 & 37.1 & 40.5 & 34.5 & .. \\
\hline 30.4 & 31.0 & 34.0 & 33.0 & 29.0 \\
\hline 21.5 & 21.5 & 20.0 & 19.0 & 17.5 \\
\hline 32.7 & 33.5 & .. & & .. \\
\hline 156.8 & 157.1 & 161.3 & 159.0 & 139.0 \\
\hline 95.0 & 96.6 & 99.3 & 101.2 & .. \\
\hline 55.5 & 54.6 & 55.4 &. & .. \\
\hline 98.3 & 111.6 & 121.6 & .. & .. \\
\hline 650.0 & 640.0 & .. & .. & .. \\
\hline 285.0 & .. & .. & .. & .. \\
\hline .. & .. & .. & .. & .. \\
\hline 12.0 & 12.4 & 12.2 & .. & .. \\
\hline 41.6 & 43.3 & 45.2 & .. & .. \\
\hline 1597.0 & 1696.0 & 1654.0 & .. & .. \\
\hline
\end{tabular}

Europe dont :

UE(27)

Autriche

Belgique

Allemagne

Italie

France

Espagne

Suède

Roy aume-Uni

Pologne

République tchèque

République slovaque

Roumanie

Turquie

Canada

Mexique

Etats-Unis

Japon

Corée

Brésil

Russie

Ukraine

Inde

Argentine

Taïpei Chinois

Chine

Source: OECD Secretariat/Secrétariat de l'OCDE 
Table 6 . TOTAL IMPORTS OF STEEL

Tableau 6. IMPORTATIONS TOTALES D'ACIER

Unit: Thousand tonnes

Unité : Milliers de tonnes

\begin{tabular}{|c|c|c|c|c|c|}
\hline \multirow[b]{2}{*}{ Europe } & 2005 & 2006 & 2007 & 2008 & \multirow[b]{2}{*}{ Europe } \\
\hline & & & & & \\
\hline E.U. 27 of which: & 26254 & 38433 & 48733 & 40156 & U.E.27 dont : \\
\hline Austria & 3879 & 3869 & 4104 & 4140 & Autriche \\
\hline Belgium & 11385 & 14522 & 16798 & 14743 & Belgique \\
\hline Germany & 20295 & 24094 & 29249 & 29560 & Allemagne \\
\hline Italy & 18254 & 23900 & 24582 & 22333 & Italie \\
\hline France & 14702 & 16639 & 17747 & 16634 & France \\
\hline Spain & 11302 & 14214 & 15020 & 11443 & Espagne \\
\hline Sweden & 3556 & 3726 & 4098 & 4017 & Suède \\
\hline United Kingdom & 7750 & 8118 & 8462 & 7242 & Roy aume-Uni \\
\hline Poland & 5041 & 6447 & 7441 & 8040 & Pologne \\
\hline Czech Republic & 4215 & 4870 & 5703 & 5983 & République tchèque \\
\hline Slovak Republic & 1423 & 1818 & 2289 & 2336 & République slovaque \\
\hline Romania & 1686 & 1746 & 3551 & 3685 & Roumanie \\
\hline Turkey & 9594 & 11719 & 13206 & 13257 & Turquie \\
\hline Canada & 9076 & 10125 & 7520 & 7006 & Canada \\
\hline Mexico & 7067 & 6093 & 5123 & 7040 & Mexique \\
\hline United States & 29642 & 41690 & 30716 & 29585 & Etats-Unis \\
\hline Japan & 6537 & 6158 & 5047 & 4485 & Japon \\
\hline Korea & 18877 & 23600 & 27900 & 28800 & Corée \\
\hline Brazil & 756 & 1817 & 1634 & 2610 & Brésil \\
\hline CIS of which: & & & & & CEI dont : \\
\hline Russia & 4562 & 5824 & 7426 & 5725 & Russie \\
\hline Ukraine & 1039 & 1512 & 2169 & 2399 & Ukraine \\
\hline Argentina & 815 & 898 & 1057 & 1253 & Argentine \\
\hline Chinese Taïpei & 11256 & 10636 & 9227 & 9250 & Taipei Chinois \\
\hline India & 3850 & 4100 & 7180 & 6973 & Inde \\
\hline Malaysia & 4416 & 4613 & 5453 & 5123 & Malaisie \\
\hline China & 27177 & 19300 & 17500 & 15771 & Chine \\
\hline
\end{tabular}

(includes all items in Harmonized System Nomenclature from 7206 to 7229

and $7301,7302,7304,7305,7306$ and from 7307.21 to 7307.99 ) 
Table 7. TOTAL EXPORTS OF STEEL

Tableau 7. EXPORTATIONS TOTALES D'ACIER

Unit: Thousand tonnes

Unité : Milliers de tonnes

\begin{tabular}{|c|c|c|c|c|c|}
\hline \multirow[b]{2}{*}{ Europe } & 2005 & 2006 & 2007 & 2008 & \multirow[b]{2}{*}{ Europe } \\
\hline & & & & & \\
\hline E.U.27 of which: & 31739 & 33152 & 33100 & 34534 & U.E.27 dont : \\
\hline Austria & 5966 & 6459 & 6847 & 7153 & Autriche \\
\hline Belgium & 16513 & 19624 & 21095 & 21034 & Belgique \\
\hline Germany & 25889 & 29219 & 30040 & 28830 & Allemagne \\
\hline Italy & 14363 & 17052 & 17908 & 18040 & Italie \\
\hline France & 17551 & 18493 & 17915 & 16846 & France \\
\hline Spain & 6661 & 6821 & 7970 & 9456 & Espagne \\
\hline Sweden & 4275 & 4069 & 4094 & 4036 & Suède \\
\hline United Kingdom & 8402 & 8135 & 8949 & 8414 & Roy aume-Uni \\
\hline Poland & 4045 & 4179 & 4988 & 5559 & Pologne \\
\hline Czech Republic & 4445 & 4910 & 3418 & 5185 & République tchèque \\
\hline Slovak Republic & 3201 & 3691 & 3397 & 4277 & République slovaque \\
\hline Romania & 3932 & 3714 & 3786 & 3193 & Roumanie \\
\hline Turkey & 11074 & 12666 & 13765 & 18494 & Turquie \\
\hline Canada & 5497 & 5799 & 7102 & 6939 & Canada \\
\hline Mexico & 6045 & 6877 & 5212 & 5766 & Mexique \\
\hline United States & 8702 & 8976 & 10844 & 12627 & Etats-Unis \\
\hline Japan & 32420 & 34990 & 36246 & 37528 & Japon \\
\hline Korea & 16262 & 18257 & 19082 & 20570 & Corée \\
\hline Brazil & 12514 & 12519 & 10427 & 9244 & Brésil \\
\hline CIS of which: & & & & & CEI dont : \\
\hline Russia & 30900 & 31000 & 29625 & 28429 & Russie \\
\hline Ukraine & 25500 & 30300 & 30308 & 28648 & Ukraine \\
\hline Argentina & 1919 & 1473 & 1411 & 1277 & Argentine \\
\hline Chinese Taïpei & 10665 & 11830 & 12197 & 10038 & Taipei Chinois \\
\hline India & 4478 & 4750 & 6614 & 7485 & Inde \\
\hline Malay sia & 2970 & 3726 & 3861 & 2754 & Malaisie \\
\hline China & 26423 & 54619 & 68547 & 59905 & Chine \\
\hline
\end{tabular}

(includes all items in Harmonized Sy stem Nomenclature from 7206 to 7229

and $7301,7302,7304,7305,7306$ and from 7307.21 to 7307.99 )

Source: OECD Secretariat/Secrétariat de l'OCDE 
Table 8. APPARENT CONSUMPTION OF FINISHED STEEL

Tableau 8. CONSOMMATION APPARENTE DE PRODUITS FINIS EN ACIER

Unit : Million tonnes

Unités : Millions de tonnes

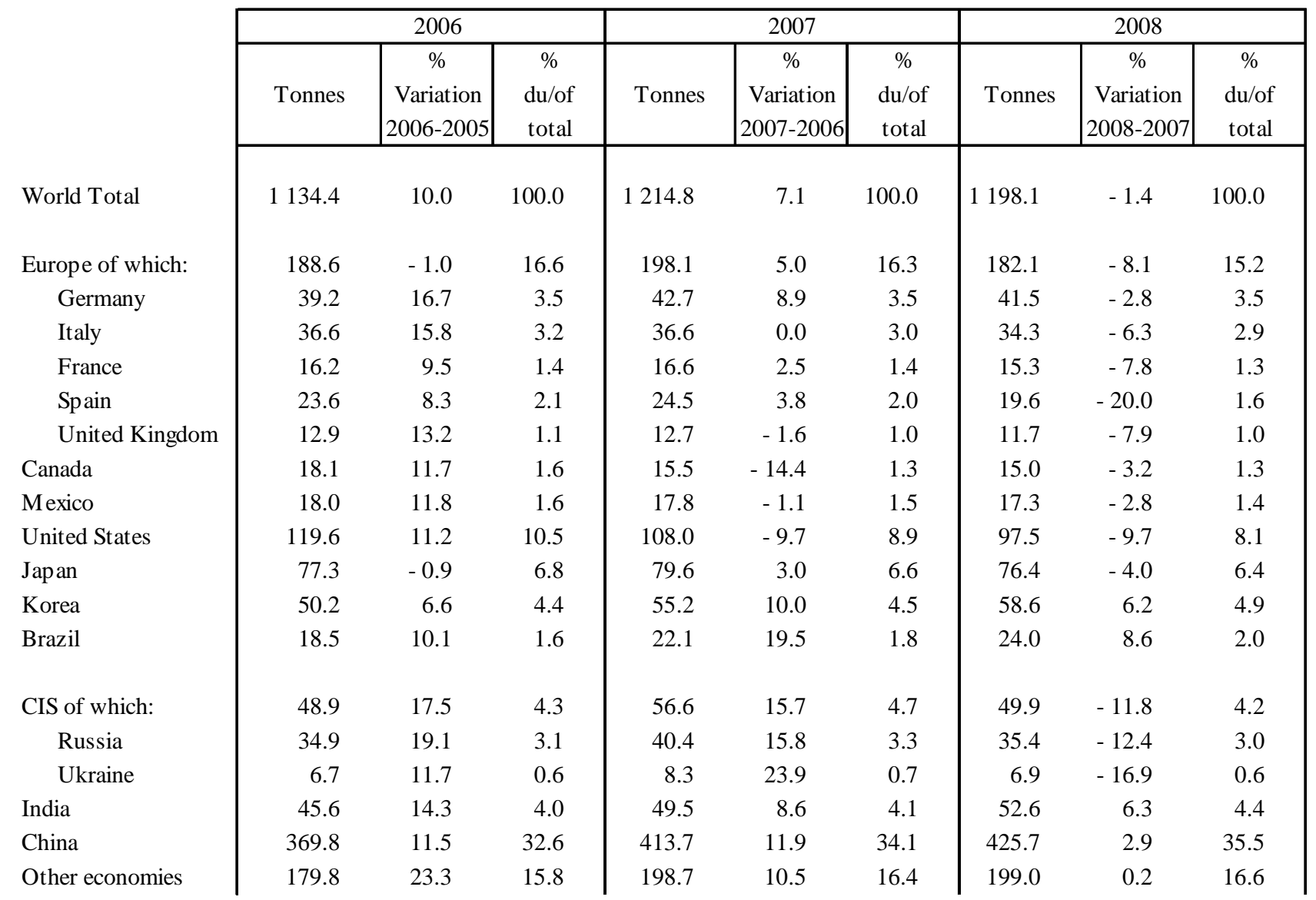

Monde Total

Europe dont :

Allemagne

Italie

France

Espagne

Roy aume-Uni

Canada

Mexique

Etats-Unis

Japon

Corée

Brésil

CEI dont :

Russie

Ukraine

Inde

Chine

Autres économies 
Table 9a. WORLD STEEL PRODUCT PRICES

Tableau 9a. PRIX MONDIAUX DES PRODUITS EN ACIER

\begin{tabular}{|c|c|c|c|c|c|c|c|c|c|}
\hline Month & $\begin{array}{l}\text { Hot } \\
\text { Rolled } \\
\text { Coil }\end{array}$ & $\begin{array}{c}\text { Hot } \\
\text { Rolled } \\
\text { Plate }\end{array}$ & $\begin{array}{c}\text { Cold } \\
\text { Rolled } \\
\text { Coil }\end{array}$ & $\begin{array}{c}\text { HD } \\
\text { Galv. } \\
\text { Coil }\end{array}$ & $\begin{array}{c}\text { Electro } \\
\text { Zinc } \\
\text { Coil }\end{array}$ & $\begin{array}{c}\text { Wire } \\
\text { Rod } \\
\text { (mesh) }\end{array}$ & $\begin{array}{l}\text { Structural } \\
\text { Sections } \\
\text { \& Beams }\end{array}$ & Rebar & $\begin{array}{c}\text { Merchant } \\
\text { Bar }\end{array}$ \\
\hline 07M1 & 549 & 747 & 647 & 866 & 804 & 495 & 735 & 512 & 590 \\
\hline $07 \mathrm{M} 2$ & 562 & 748 & 654 & 873 & 806 & 507 & 751 & 535 & 609 \\
\hline 07M3 & 577 & 758 & 670 & 890 & 802 & 533 & 768 & 589 & 618 \\
\hline $07 \mathrm{M} 4$ & 617 & 788 & 698 & 893 & 821 & 577 & 798 & 615 & 646 \\
\hline 07M5 & 623 & 800 & 696 & 890 & 827 & 606 & 815 & 622 & 659 \\
\hline 07M6 & 611 & 800 & 686 & 876 & 821 & 602 & 812 & 617 & 653 \\
\hline 07M7 & 599 & 808 & 681 & 856 & 817 & 590 & 819 & 591 & 646 \\
\hline 07M8 & 603 & 814 & 686 & 863 & 823 & 594 & 825 & 596 & 650 \\
\hline 07M9 & 602 & 810 & 673 & 851 & 817 & 580 & 821 & 589 & 655 \\
\hline 07M10 & 611 & 826 & 680 & 850 & 811 & 584 & 844 & 595 & 670 \\
\hline 07M11 & 615 & 833 & 688 & 862 & 819 & 584 & 853 & 591 & 678 \\
\hline $07 \mathrm{M} 12$ & 630 & 837 & 705 & 870 & 833 & 598 & 859 & 599 & 681 \\
\hline 08M1 & 639 & 847 & 716 & 880 & 826 & 621 & 871 & 631 & 695 \\
\hline $08 \mathrm{M} 2$ & 699 & 887 & 772 & 920 & 830 & 687 & 905 & 702 & 749 \\
\hline 08M3 & 800 & 978 & 890 & 1029 & 953 & 758 & 970 & 761 & 818 \\
\hline 08M4 & 915 & 1065 & 985 & 1130 & 1058 & 852 & 1042 & 871 & 938 \\
\hline 08M5 & 998 & 1160 & 1080 & 1202 & 1135 & 920 & 1105 & 938 & 998 \\
\hline 08M6 & 1073 & 1225 & 1144 & 1275 & 1190 & 1005 & 1184 & 1016 & 1070 \\
\hline 08M7 & 1099 & 1307 & 1186 & 1311 & 1228 & 1067 & 1234 & 1068 & 1113 \\
\hline 08M8 & 1093 & 1300 & 1179 & 1304 & 1222 & 1062 & 1227 & 1061 & 1106 \\
\hline 08M9 & 973 & 1243 & 1046 & 1174 & 1132 & 977 & 1154 & 914 & 1006 \\
\hline 08M10 & 865 & 1150 & 940 & 1079 & 1079 & 811 & 1045 & 734 & 896 \\
\hline 08M11 & 716 & 1000 & 802 & 938 & 908 & 676 & 898 & 576 & 785 \\
\hline 08M12 & 565 & 901 & 659 & 801 & 775 & 609 & 780 & 590 & 726 \\
\hline 09M1 & 575 & 806 & 666 & 793 & 777 & 626 & 791 & 596 & 753 \\
\hline 09M2 & 556 & 719 & 637 & 750 & 732 & 574 & 753 & 539 & 713 \\
\hline 09M3 & 505 & 643 & 594 & 697 & 679 & 526 & 714 & 481 & 622 \\
\hline 09M4 & 487 & 638 & 576 & 676 & 677 & 500 & 678 & 485 & 623 \\
\hline 09M5 & 474 & 605 & 556 & 665 & 644 & 490 & 692 & 500 & 639 \\
\hline 09M6 & 495 & 604 & 579 & 684 & 666 & 508 & 701 & 503 & 649 \\
\hline 09M7 & 513 & 604 & 598 & 698 & 660 & 515 & 682 & 508 & 644 \\
\hline 09M8 & 544 & 622 & 636 & 733 & 694 & 527 & 697 & 522 & 658 \\
\hline 09M9 & 590 & 641 & 680 & 792 & 762 & 547 & 706 & 539 & 659 \\
\hline 09M10 & 592 & 655 & 692 & 799 & 796 & 551 & 699 & 539 & 654 \\
\hline 09M11 & 575 & 643 & 674 & 772 & 778 & 538 & 677 & 510 & 639 \\
\hline 09M12 & 579 & 639 & 681 & 780 & 783 & 555 & 691 & 527 & 639 \\
\hline
\end{tabular}

Table 9b. WORLD STEEL PRODUCT PRICE INDEXES (BASED ON USD VALUES)

Tableau 9b. INDICES DES PRIX MONDIAUX DES PRODUITS EN ACIER (BASE : VALEUR USD)

\begin{tabular}{|c|c|c|c|c|c|c|c|c|c|}
\hline Month & $\begin{array}{c}\text { Hot } \\
\text { Rolled } \\
\text { Coil }\end{array}$ & $\begin{array}{c}\text { Hot } \\
\text { Rolled } \\
\text { Plate }\end{array}$ & $\begin{array}{c}\text { Cold } \\
\text { Rolled } \\
\text { Coil }\end{array}$ & $\begin{array}{c}\text { HD } \\
\text { Galv. } \\
\text { Coil }\end{array}$ & $\begin{array}{c}\text { Electro } \\
\text { Zinc } \\
\text { Coil }\end{array}$ & $\begin{array}{c}\text { Wire } \\
\text { Rod } \\
\text { (mesh) }\end{array}$ & $\begin{array}{l}\text { Structural } \\
\text { Sections } \\
\& \text { Beams }\end{array}$ & $\begin{array}{l}\text { Rebar } \\
\end{array}$ & $\begin{array}{c}\text { Merchant } \\
\text { Bar }\end{array}$ \\
\hline 07M1 & 156.0 & 190.1 & 136.2 & 149.3 & 136.3 & 159.7 & 171.3 & 167.9 & 176.1 \\
\hline 07M2 & 159.7 & 190.3 & 137.7 & 150.5 & 136.6 & 163.5 & 175.1 & 175.4 & 181.8 \\
\hline 07M3 & 163.9 & 192.9 & 141.1 & 153.4 & 135.9 & 171.9 & 179.0 & 193.1 & 184.5 \\
\hline $07 \mathrm{M} 4$ & 175.3 & 200.5 & 146.9 & 154.0 & 139.2 & 186.1 & 186.0 & 201.6 & 192.8 \\
\hline 07M5 & 177.0 & 203.6 & 146.5 & 153.4 & 140.2 & 195.5 & 190.0 & 203.9 & 196.7 \\
\hline 07M6 & 173.6 & 203.6 & 144.4 & 151.0 & 139.2 & 194.2 & 189.3 & 202.3 & 194.9 \\
\hline 07M7 & 170.2 & 205.6 & 143.4 & 147.6 & 138.5 & 1990.3 & 190.9 & 193.8 & 192.8 \\
\hline 07M8 & 171.3 & 207.1 & 144.4 & 148.0 & 139.5 & 191.6 & 192.3 & 195.4 & 194.0 \\
\hline 07M9 & 171.0 & 206.1 & 141.7 & 146.7 & 138.5 & 187.1 & 191.4 & 193.1 & 195.5 \\
\hline $07 \mathrm{M} 10$ & 173.6 & 210.2 & 143.2 & 146.6 & 137.5 & 188.4 & 196.7 & 195.1 & 200.0 \\
\hline 07M11 & 174.7 & 212 & 144.8 & 148.6 & 138.8 & 188.4 & 198.8 & 193.8 & 202.4 \\
\hline $07 \mathrm{M} 12$ & 179 & 213 & 148.4 & 150 & 141.2 & 192.9 & 200.2 & 196.4 & 203.3 \\
\hline 08M1 & 181.5 & 215.5 & 150.7 & 151.7 & 140 & 200.3 & 203 & 206.9 & 207.5 \\
\hline 08M2 & 198.6 & 225.7 & 162.5 & 158.6 & 140.7 & 221.6 & 211 & 230.2 & 223.6 \\
\hline 08M3 & 227.3 & 248.9 & 187.4 & 177.4 & 161.5 & 244.5 & 226.1 & 249.5 & 244.2 \\
\hline 08M4 & 259.9 & 271 & 207.4 & 194.8 & 179.3 & 274.8 & 242.9 & 285.6 & 280 \\
\hline 08M5 & 283.5 & 295.2 & 227.4 & 207.2 & 192.4 & 296.8 & 257.6 & 307.5 & 297.9 \\
\hline 08M6 & 304.8 & 311.7 & 240.8 & 219.8 & 201.7 & 324.2 & 276 & 333.1 & 319.4 \\
\hline 08M7 & 312.2 & 332.6 & 249.7 & 226 & 208.1 & 344.2 & 287.6 & 350.2 & 332.2 \\
\hline 08M8 & 310.5 & 330.8 & 248.2 & 224.8 & 207.1 & 342.6 & 286 & 347.9 & 330.1 \\
\hline 08M9 & 276.4 & 316.3 & 220.2 & 202.4 & 191.9 & 315.2 & 269 & 299.7 & 300.3 \\
\hline 08M 10 & 245.7 & 292.6 & 197.9 & 186 & 182.9 & 261.6 & 243.6 & 240.7 & 267.5 \\
\hline 08M11 & 203.4 & 254.5 & 168.8 & 161.7 & 153.9 & 218.1 & 209.3 & 188.9 & 234.3 \\
\hline $08 \mathrm{M} 12$ & 160.5 & 229.3 & 138.7 & 138.1 & 131.4 & 196.5 & 181.8 & 193.4 & 216.7 \\
\hline 09M1 & 163.4 & 205.1 & 140.2 & 136.7 & 131.7 & 201.9 & 184.4 & 195.4 & 224.8 \\
\hline 09M2 & 158.0 & 183.0 & 134.1 & 129.3 & 124.1 & 185.2 & 175.5 & 176.7 & 212.8 \\
\hline 09M3 & 143.5 & 163.6 & 125.1 & 120.2 & 115.1 & 169.7 & 166.4 & 157.7 & 185.7 \\
\hline 09M4 & 138.4 & 162.3 & 121.3 & 116.6 & 114.7 & 161.3 & 158.0 & 159.0 & 186.0 \\
\hline 09M5 & 134.7 & 153.9 & 117.1 & 114.7 & 109.2 & 158.1 & 161.3 & 163.9 & 190.7 \\
\hline 09M6 & 140.6 & 153.7 & 121.9 & 117.9 & 112.9 & 163.9 & 163.4 & 164.9 & 193.7 \\
\hline 09M7 & 145.7 & 153.7 & 125.9 & 120.3 & 111.9 & 166.1 & 159.0 & 166.6 & 192.2 \\
\hline 09M8 & 154.5 & 158.3 & 133.9 & 126.4 & 117.6 & 170.0 & 162.5 & $171 . .1$ & 196.4 \\
\hline 09M9 & 167.6 & 163.1 & 143.2 & 136.6 & 129.2 & 176.5 & 164.6 & 176.7 & 196.7 \\
\hline 09M10 & 168.2 & 166.7 & 145.7 & 137.8 & 134.9 & 177.7 & 162.9 & 176.7 & 195.2 \\
\hline 09M11 & 163.4 & 163.6 & 141.9 & 133.1 & 131.9 & 173.5 & 157.8 & 167.2 & 190.7 \\
\hline 09M12 & 164.5 & 162.6 & 143.4 & 134.5 & 132.7 & 179.0 & 161.1 & 172.8 & 190.7 \\
\hline
\end{tabular}

Note: Prices are an arithmetic average of the low transaction values identified in three regions (EU, Asia, and North America), converted into US dollars. Source: MEPS International Ltd. 
Table 10a. EUROPEAN UNION STEEL PRODUCT PRICES

Tableau 10a. PRIX DES PRODUITS EN ACIER DE L'UNION EUROPENNE

\begin{tabular}{|c|c|c|c|c|c|c|c|}
\hline Month & $\begin{array}{l}\text { Hot Rolled } \\
\text { Coil }\end{array}$ & $\begin{array}{c}\text { Hot Rolled } \\
\text { Plate }\end{array}$ & $\begin{array}{l}\text { Cold Rolled } \\
\text { Coil }\end{array}$ & $\begin{array}{c}\text { HD Galv. } \\
\text { Coil }\end{array}$ & $\begin{array}{l}\text { Wire Rod } \\
\text { (mesh) }\end{array}$ & $\begin{array}{c}\text { Structural } \\
\text { Sections \& } \\
\text { Beams }\end{array}$ & $\begin{array}{c}\text { Reinforcing } \\
\text { Bar }\end{array}$ \\
\hline 07M1 & 476 & 678 & 576 & 743 & 403 & 779 & 421 \\
\hline 07M2 & 486 & 681 & 581 & 750 & 420 & 782 & 440 \\
\hline 07M3 & 489 & 683 & 583 & 761 & 438 & 793 & 523 \\
\hline $07 \mathrm{M} 4$ & 526 & 693 & 606 & 737 & 487 & 815 & 554 \\
\hline 07M5 & 526 & 692 & 607 & 737 & 503 & 816 & 549 \\
\hline 07M6 & 519 & 694 & 599 & 731 & 499 & 812 & 539 \\
\hline 07M7 & 513 & 706 & 595 & 707 & 473 & 818 & 478 \\
\hline 07M8 & 512 & 706 & 595 & 707 & 473 & 817 & 478 \\
\hline 07M9 & 511 & 701 & 575 & 683 & 451 & 801 & 454 \\
\hline 07M10 & 499 & 701 & 563 & 647 & 432 & 795 & 430 \\
\hline 07M11 & 490 & 697 & 558 & 637 & 411 & 791 & 410 \\
\hline 07M12 & 485 & 691 & 554 & 630 & 411 & 779 & 406 \\
\hline 08M1 & 480 & 696 & 551 & 620 & 423 & 773 & 437 \\
\hline 08M2 & 507 & 708 & 565 & 634 & 500 & 798 & 528 \\
\hline 08M3 3 & 585 & 748 & 664 & 748 & 547 & 816 & 539 \\
\hline 08M4 & 676 & 803 & 730 & 811 & 619 & 833 & 609 \\
\hline 08M5 & 701 & 830 & 763 & 835 & 701 & 899 & 698 \\
\hline 08M6 & 743 & 890 & 790 & 874 & 760 & 977 & 772 \\
\hline 08M7 7 & 790 & 917 & 856 & 929 & 814 & 1008 & 822 \\
\hline 08M8 & 791 & 917 & 856 & 930 & 814 & 1009 & 822 \\
\hline 08M9 & 779 & 939 & 828 & 904 & 739 & 973 & 712 \\
\hline 08M10 & 711 & 892 & 780 & 860 & 552 & 892 & 500 \\
\hline 08M11 & 600 & 797 & 680 & 761 & 433 & 781 & 403 \\
\hline 08M12 & 439 & 683 & 513 & 593 & 418 & 650 & 435 \\
\hline 09M1 & 435 & 673 & 514 & 560 & 429 & 611 & 428 \\
\hline 09M2 & 430 & 550 & 507 & 549 & 411 & 562 & 388 \\
\hline 09M3 & 389 & 519 & 475 & 520 & 349 & 560 & 339 \\
\hline 09M4 & 358 & 497 & 446 & 486 & 325 & 510 & 322 \\
\hline 09M5 & 354 & 466 & 435 & 478 & 346 & 515 & 361 \\
\hline 09M6 & 361 & 444 & 432 & 478 & 349 & 513 & 341 \\
\hline 09M7 & 370 & 435 & 438 & 487 & 333 & 486 & 326 \\
\hline 09M8 & 370 & 435 & 438 & 487 & 333 & 486 & 326 \\
\hline 09M9 & 433 & 465 & 495 & 550 & 375 & 522 & 370 \\
\hline 09M10 & 418 & 456 & 488 & 538 & 367 & 510 & 353 \\
\hline 09M11 & 401 & 457 & 476 & 520 & 339 & 484 & 321 \\
\hline 09M12 & 392 & 435 & 466 & 511 & 351 & 491 & 341 \\
\hline
\end{tabular}

Table 10b. EUROPEAN UNION STEEL PRODUCT PRICE INDEXES (BASED ON EURO VALUES) Tableau 10b. INDICES DE PRIX DES PRODUITS EN ACIER DE L'UNION EUROPENNE

$$
\text { (BASE: VALEUR EURO) }
$$

\begin{tabular}{|c|c|c|c|c|c|c|c|}
\hline Month & $\begin{array}{l}\text { Hot Rolled } \\
\text { Coil }\end{array}$ & $\begin{array}{c}\text { Hot Rolled } \\
\text { Plate }\end{array}$ & $\begin{array}{l}\text { Cold Rolled } \\
\text { Coil }\end{array}$ & $\begin{array}{c}\text { HD Galv. } \\
\text { Coil }\end{array}$ & 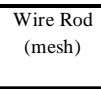 & $\begin{array}{c}\text { Structural } \\
\text { Sections \& } \\
\text { Beams }\end{array}$ & $\begin{array}{c}\text { Reinforcing } \\
\text { Bar }\end{array}$ \\
\hline 07M1 & 182.4 & 236.2 & 158.2 & 161.2 & 170.0 & 223.2 & 185.5 \\
\hline 07M2 & 186.2 & 237.3 & 159.6 & 162.7 & 177.2 & 224.1 & 193.8 \\
\hline $07 \mathrm{M} 3$ & 187.4 & 238.0 & 160.2 & 165.1 & 184.8 & 227.2 & 230.4 \\
\hline $07 \mathrm{M} 4$ & 201.5 & 241.5 & 166.5 & 159.9 & 205.5 & 233.5 & 244.1 \\
\hline 07M5 & 201.5 & 241.1 & 166.8 & 159.9 & 212.2 & 233.8 & 241.9 \\
\hline 07M6 & 198.9 & 241.8 & 164.6 & 158.6 & 210.5 & 232.7 & $237 . .4$ \\
\hline 07M7 & 196.6 & 246.0 & 163.5 & 153.4 & 199.6 & 234.4 & 210.6 \\
\hline 07M8 & 196.2 & 246.0 & 163.5 & 153.4 & 199.6 & 234.1 & 210.6 \\
\hline $07 \mathrm{M} 9$ & 195.8 & 244.3 & 158.0 & 148.2 & 190.3 & 229.5 & 200.0 \\
\hline 07M10 & 191.2 & 244.3 & 154.7 & 140.3 & 182.3 & 227.8 & 189.4 \\
\hline 07M11 & 187.7 & 242.9 & 153.3 & 138.2 & 173.4 & 226.6 & 180.6 \\
\hline $07 \mathrm{M} 12$ & 185.8 & 240.8 & 152.2 & 136.7 & 173.4 & 223.2 & 178.9 \\
\hline 08M1 & 183.9 & 242.5 & 151.4 & 134.5 & 178.5 & 221.5 & 192.5 \\
\hline 08M2 & 194.3 & 246.7 & 155.2 & 137.5 & 211.0 & 228.7 & 232.6 \\
\hline $08 \mathrm{M} 3$ & 224.1 & 260.6 & 182.4 & 162.3 & 230.8 & 233.8 & 237.4 \\
\hline $08 \mathrm{M} 4$ & 259.0 & 279.8 & 200.5 & 175.9 & 261.2 & 238.7 & 268.3 \\
\hline 08M5 & 268.6 & 289.2 & 209.6 & 181.1 & 295.8 & 257.6 & 307.5 \\
\hline $08 \mathrm{M} 6$ & 284.7 & 310.1 & 217.0 & 189.6 & 320.7 & 279.9 & 340.1 \\
\hline 08M7 & 302.7 & 319.5 & 235.2 & 201.5 & 343.5 & 288.8 & 362.1 \\
\hline 08M8 & 303.1 & 319.5 & 235.2 & 201.7 & 343.5 & 289.1 & 362.1 \\
\hline 08M9 & 298.5 & 327.2 & 227.5 & 196.1 & 311.8 & 278.8 & 313.7 \\
\hline 08M10 & 272.4 & 310.8 & 214.3 & 186.6 & 232.9 & 255.6 & 220.3 \\
\hline 08M11 & 229.9 & 277.7 & 186.8 & 165.1 & 182.7 & 223.8 & 177.5 \\
\hline $08 \mathrm{M} 12$ & 168.2 & 238.0 & 140.9 & 128.7 & 176.4 & 186.3 & 191.6 \\
\hline 09M1 & 166.7 & 234.5 & 141.2 & 121.5 & 181.0 & 175.1 & 188.5 \\
\hline 09M2 & 164.8 & 191.6 & 139.3 & 119.1 & 173.4 & 161.0 & 170.9 \\
\hline 09M3 & 149.1 & 180.8 & 130.5 & 112.8 & 147.3 & 160.5 & 149.3 \\
\hline 09M4 & 137.2 & 173.2 & 122.5 & 105.4 & 137.1 & 146.1 & 141.8 \\
\hline 09M5 & 135.6 & 162.4 & 119.5 & 103.7 & 146.0 & 147.6 & 159.0 \\
\hline 09M6 & 138.3 & 154.7 & 118.7 & 103.7 & 147.3 & 147.0 & 150.2 \\
\hline 09M7 & 141.8 & 151.6 & 120.3 & 105.7 & 140.5 & 139.3 & 143.6 \\
\hline 09M8 & 141.8 & 151.6 & 120.3 & 105.7 & 140.5 & 139.3 & 143.6 \\
\hline 09M9 & 165.9 & 162.0 & 136.0 & 119.3 & 158.2 & 149.6 & 163.0 \\
\hline 09M10 & 160.2 & 158.9 & 134.1 & 116.7 & 154.9 & 146.1 & 155.5 \\
\hline 09M11 & 153.6 & 159.2 & 130.8 & 112.8 & 143.0 & 138.7 & 141.4 \\
\hline & & & & & & & \\
\hline
\end{tabular}

Note: Prices are computed from a weighted average (based on consumption) of the low values identified in the top five consuming countries for each product in the relevant period collected in national currencies and converted into Euros using currency exchange rates effective at the start of each month.

Source: MEPS International Ltd.

THE IRON AND STEEL INDUSTRY IN 2009 - @ OECD 2010 
Table 11a. NORTH AMERICAN STEEL PRODUCT PRICES

Tableau 11a. PRIX DES PRODUITS EN ACIER NORD-AMERICAINS

\begin{tabular}{|c|c|c|c|c|c|c|c|}
\hline Month & $\begin{array}{l}\text { Hot Rolled } \\
\text { Coil }\end{array}$ & $\begin{array}{l}\text { Hot Rolled } \\
\text { Plate }\end{array}$ & $\begin{array}{l}\text { Cold Rolled } \\
\text { Coil }\end{array}$ & $\begin{array}{l}\text { HD Galv. } \\
\text { Coil }\end{array}$ & $\begin{array}{l}\text { Wire Rod } \\
\text { (mesh) }\end{array}$ & $\begin{array}{c}\text { Structural } \\
\text { Sections \& } \\
\text { Beams }\end{array}$ & $\begin{array}{c}\text { Reinforcing } \\
\text { Bar }\end{array}$ \\
\hline 07M 1 & 561 & 812 & 642 & 809 & 545 & 684 & 542 \\
\hline 07M2 & 578 & 808 & 647 & 824 & 545 & 711 & 571 \\
\hline 07M3 & 601 & 819 & 676 & 844 & 575 & 726 & 602 \\
\hline 07M4 & 652 & 879 & 714 & 871 & 620 & 759 & 620 \\
\hline 07M5 & 648 & 886 & 687 & 844 & 660 & 779 & 629 \\
\hline 07M6 & 629 & 887 & 678 & 835 & 660 & 782 & 632 \\
\hline $07 \mathrm{M} 7$ & 605 & 883 & 663 & 805 & 660 & 780 & 631 \\
\hline 07M8 & 606 & 884 & 664 & 806 & 660 & 781 & 632 \\
\hline 07M9 & 596 & 841 & 651 & 804 & 630 & 781 & 619 \\
\hline $07 \mathrm{M} 10$ & 604 & 845 & 661 & 822 & 630 & 805 & 621 \\
\hline 07M11 & 608 & 840 & 664 & 835 & 630 & 805 & 620 \\
\hline $07 \mathrm{M} 12$ & 625 & 822 & 684 & 850 & 630 & 798 & 615 \\
\hline 08M1 & 655 & 847 & 709 & 889 & 660 & 827 & 645 \\
\hline 08M2 & 768 & 904 & 837 & 988 & 710 & 870 & 682 \\
\hline $08 \mathrm{M} 3$ & 802 & 966 & 871 & 1021 & 765 & 892 & 720 \\
\hline 08M4 & 929 & 1062 & 970 & 1132 & 880 & 1004 & 870 \\
\hline 08M5 & 1133 & 1342 & 1208 & 1372 & 950 & 1058 & 918 \\
\hline 08M6 & 1200 & 1356 & 1255 & 1423 & 1030 & 1092 & 975 \\
\hline 08M7 & 1199 & 1532 & 1272 & 1441 & 1100 & 1155 & 1041 \\
\hline 08M8 & 1194 & 1527 & 1270 & 1438 & 1100 & 1152 & 1039 \\
\hline 08M9 & 1033 & 1485 & 1107 & 1272 & 1070 & 1150 & 948 \\
\hline 08M10 & 955 & 1397 & 991 & 1160 & 980 & 1054 & 858 \\
\hline 08M11 & 797 & 1272 & 872 & 1037 & 880 & 965 & 664 \\
\hline 08M 12 & 582 & 1171 & 692 & 901 & 770 & 894 & 658 \\
\hline 09M1 & 570 & 886 & 640 & 846 & 770 & 903 & 658 \\
\hline 09M2 & 567 & 837 & 619 & 803 & 660 & 882 & 566 \\
\hline 09M3 & 539 & 709 & 606 & 764 & 660 & 841 & 537 \\
\hline 09M4 & 496 & 703 & 559 & 721 & 590 & 763 & 542 \\
\hline 09M5 & 471 & 620 & 524 & 689 & 500 & 759 & 506 \\
\hline 09M6 & 484 & 586 & 535 & 685 & 530 & 776 & 508 \\
\hline 09M7 & 506 & 630 & 571 & 736 & 570 & 775 & 542 \\
\hline 09M8 & 570 & 645 & 644 & 809 & 580 & 781 & 546 \\
\hline 09M9 & 609 & 643 & 682 & 844 & 580 & 742 & 545 \\
\hline 09M10 & 615 & 674 & 703 & 865 & 580 & 705 & 547 \\
\hline 09M11 & 591 & 634 & 663 & 822 & 580 & 699 & 528 \\
\hline & 50 & 636 & & & 580 & & \\
\hline
\end{tabular}

Table 11b. NORTH AMERICAN STEEL PRODUCT PRICE INDEXES (BASED ON USD VALUES) Tableau 11b. INDICES DE PRIX DES PRODUITS EN ACIER NORD-AMERICAINS (BASE: VALEUR USD)

\begin{tabular}{|c|c|c|c|c|c|c|c|}
\hline Month & $\begin{array}{l}\text { Hot Rolled } \\
\text { Coil }\end{array}$ & $\begin{array}{l}\text { Hot Rolled } \\
\text { Plate }\end{array}$ & $\begin{array}{c}\text { Cold Rolled } \\
\text { Coil }\end{array}$ & $\begin{array}{c}\text { HD Galv. } \\
\text { Coil }\end{array}$ & $\begin{array}{c}\text { Wire Rod } \\
\text { (mesh) }\end{array}$ & $\begin{array}{c}\text { Structural } \\
\text { Sections \& } \\
\text { Beams } \\
\end{array}$ & $\begin{array}{c}\text { Reinforcing } \\
\text { Bar }\end{array}$ \\
\hline 07M 1 & 140.3 & 178.5 & 124.7 & 135.5 & 175.8 & 155.5 & 164.2 \\
\hline $07 \mathrm{M} 2$ & 144.5 & 177.6 & 125.6 & 138.0 & 175.8 & 161.6 & 173.0 \\
\hline $07 \mathrm{M} 3$ & 150.3 & 180.0 & 131.3 & 141.4 & 185.5 & 165.0 & 182.4 \\
\hline $07 \mathrm{M} 4$ & 163.0 & 193.2 & 138.6 & 145.9 & 200.0 & 172.5 & 187.9 \\
\hline 07M5 & 162.0 & 194.7 & 133.4 & 141.4 & 212.9 & 177.0 & 190.6 \\
\hline 07M6 & 157.3 & 194.9 & 131.7 & 139.9 & 212.9 & 177.7 & 191.5 \\
\hline $07 \mathrm{M} 7$ & 151.3 & 194.1 & 128.7 & 134.8 & 212.9 & 177.3 & 191.2 \\
\hline 07M8 & 151.5 & 194.3 & 128.9 & 135.0 & 212.9 & 177.5 & 191.5 \\
\hline 07M9 & 149.0 & 184.8 & 126.4 & 134.7 & 203.2 & 177.5 & 187.6 \\
\hline $07 \mathrm{M} 10$ & 151.0 & 185.7 & 128.3 & 137.7 & 203.2 & 183.0 & 188.2 \\
\hline 07M11 & 152.0 & 184.6 & 128.9 & 139.9 & 203.2 & 183.0 & 187.9 \\
\hline $07 \mathrm{M} 12$ & 156.3 & 180.7 & 132.8 & 142.4 & 203.2 & 181.4 & 186.4 \\
\hline 08M1 & 163.8 & 186.2 & 137.7 & 148.9 & 212.9 & 188.0 & 195.5 \\
\hline 08M2 & 192.0 & 198.7 & 162.5 & 165.5 & 229.0 & 197.7 & 206.7 \\
\hline 08M3 & 200.5 & 212.3 & 169.1 & 171.0 & 246.8 & 202.7 & 218.2 \\
\hline 08M4 & 232.3 & 233.4 & 188.3 & 189.6 & 283.9 & 228.2 & 263.6 \\
\hline 08M5 & 283.3 & 294.9 & 234.6 & 229.8 & 306.5 & 240.5 & 278.2 \\
\hline 08M6 & 300.0 & 298.0 & 243.7 & 238.4 & 332.3 & 248.2 & 295.5 \\
\hline 08M7 & 299.8 & 336.7 & 247.0 & 241.4 & 354.8 & 262.5 & 315.5 \\
\hline 08M8 & 298.5 & 335.6 & 246.6 & 240.9 & 354.8 & 261.8 & 314.8 \\
\hline 08M9 & 258.3 & 326.4 & 215.0 & 213.1 & 345.2 & 261.4 & 287.3 \\
\hline 08M10 & 238.8 & 307.0 & 192.4 & 194.3 & 316.1 & 239.5 & 260.0 \\
\hline 08M11 & 199.3 & 279.6 & 169.3 & 173.7 & 283.9 & 219.3 & 201.2 \\
\hline $08 \mathrm{M} 12$ & 145.5 & 257.4 & 134.4 & 150.9 & 248.4 & 203.2 & 199.4 \\
\hline 09M1 & 142.5 & 194.7 & 124.3 & 141.7 & 248.4 & 205.2 & 199.4 \\
\hline 09M2 & 141.8 & 184.0 & 120.2 & 134.5 & 212.9 & 200.5 & 171.5 \\
\hline 09M3 & 134.8 & 155.8 & 117.7 & 128.0 & 212.9 & 191.1 & 162.7 \\
\hline 09M4 & 124.0 & 154.5 & 108.5 & 120.8 & 190.3 & 173.4 & 164.2 \\
\hline 09M5 & 117.8 & 136.3 & 101.7 & 115.4 & 161.3 & 172.5 & 153.3 \\
\hline 09M6 & 121.0 & 128.8 & 103.9 & 114.7 & 171.0 & 176.4 & 153.9 \\
\hline 09M7 & 126.5 & 138.5 & 110.9 & 123.3 & 183.9 & 176.1 & 164.2 \\
\hline 09M8 & 142.5 & 141.8 & 125.0 & 135.5 & 187.1 & 177.5 & 165.5 \\
\hline 09M9 & 152.3 & 141.3 & 132.4 & 141.4 & 187.1 & 168.6 & 165.2 \\
\hline 09M10 & 153.8 & 148.1 & 136.5 & 144.9 & 187.1 & 160.2 & 165.8 \\
\hline 09M11 & 147.8 & 139.3 & 128.7 & 137.7 & 187.1 & 158.9 & 160.0 \\
\hline $09 \mathrm{M} 12$ & 147.8 & 139.8 & 128.9 & 137.9 & 187.1 & 159.1 & 159.4 \\
\hline
\end{tabular}

Note: Prices are computed from an arithmetic average of the low prices identified in USA (midwest) and Canada collected in national currencies and converted into US Dollars using currency exchange rates effective at the start of each month. 
Table 12a. ASIAN STEEL PRODUCT PRICES

Tableau 12a. PRIX DES PRODUITS EN ACIER D'ASIE

\begin{tabular}{|c|c|c|c|c|c|c|c|}
\hline Month & $\begin{array}{c}\text { Hot Rolled } \\
\text { Coil }\end{array}$ & $\begin{array}{l}\text { Hot Rolled } \\
\text { Plate }\end{array}$ & $\begin{array}{l}\text { Cold Rolled } \\
\text { Coil }\end{array}$ & $\begin{array}{c}\text { HD Galv. } \\
\text { Coil }\end{array}$ & $\begin{array}{l}\text { Wire Rod } \\
\text { (mesh) }\end{array}$ & $\begin{array}{c}\text { Structural } \\
\text { Sections \& } \\
\text { Beams }\end{array}$ & $\begin{array}{c}\text { Reinforcing } \\
\text { Bar }\end{array}$ \\
\hline 07M1 & 467 & 548 & 552 & 823 & 416 & 508 & 447 \\
\hline 07M2 & 474 & 548 & 559 & 817 & 427 & 521 & 459 \\
\hline 07M3 & 486 & 556 & 569 & 827 & 448 & 535 & 479 \\
\hline 07M4 & 497 & 559 & 569 & 822 & 459 & 546 & 484 \\
\hline 07M5 & 503 & 570 & 574 & 822 & 472 & 555 & 489 \\
\hline 07M6 & 503 & 575 & 573 & 807 & 472 & 559 & 491 \\
\hline 07M7 7 & 492 & 578 & 568 & 800 & 467 & 562 & 491 \\
\hline 07M8 & 496 & 583 & 572 & 809 & 471 & 566 & 496 \\
\hline 07M9 & 510 & 628 & 581 & 814 & 493 & 584 & 525 \\
\hline $07 \mathrm{M} 10$ & 522 & 641 & 584 & 813 & 512 & 603 & 555 \\
\hline 07M11 & 529 & 650 & 592 & 829 & 528 & 609 & 561 \\
\hline $07 \mathrm{M} 12$ & 549 & 670 & 613 & 831 & 557 & 630 & 582 \\
\hline 08M1 & 554 & 668 & 626 & 837 & 580 & 646 & 604 \\
\hline 08M2 & 592 & 730 & 658 & 853 & 625 & 687 & 658 \\
\hline 08M3 & 701 & 820 & 782 & 918 & 669 & 765 & 735 \\
\hline 08M4 & 748 & 864 & 832 & 978 & 699 & 806 & 782 \\
\hline 08M5 & 780 & 860 & 857 & 948 & 729 & 872 & 821 \\
\hline 08M6 & 864 & 936 & 948 & 1044 & 804 & 940 & 872 \\
\hline 08M7 7 & 863 & 955 & 946 & 1038 & 828 & 970 & 876 \\
\hline 08M8 & 860 & 952 & 943 & 1034 & 826 & 967 & 873 \\
\hline 08M99 & 785 & 919 & 863 & 972 & 816 & 938 & 788 \\
\hline 08M10 & 671 & 836 & 766 & 903 & 700 & 864 & 663 \\
\hline 08M11 & 570 & 691 & 648 & 785 & 584 & 712 & 540 \\
\hline 08M12 & 555 & 664 & 632 & 747 & 525 & 619 & 560 \\
\hline 09M1 & 574 & 632 & 669 & 782 & 534 & 652 & 558 \\
\hline 09M2 & 541 & 605 & 634 & 734 & 529 & 647 & 546 \\
\hline 09M3 & 483 & 562 & 575 & 668 & 476 & 592 & 477 \\
\hline 09M4 & 490 & 553 & 580 & 664 & 480 & 597 & 488 \\
\hline 09M5 & 477 & 573 & 561 & 667 & 506 & 627 & 510 \\
\hline 09M6 & 493 & 599 & 593 & 694 & 502 & 603 & 512 \\
\hline 09M7 & 519 & 579 & 616 & 683 & 512 & 596 & 530 \\
\hline 09M8 & 531 & 597 & 636 & 691 & 524 & 613 & 551 \\
\hline 09M9 & 540 & 613 & 649 & 744 & 525 & 628 & 541 \\
\hline 09M10 & 550 & 624 & 659 & 744 & 535 & 645 & 553 \\
\hline 09M11 & 543 & 619 & 655 & 727 & 532 & 618 & 529 \\
\hline 09M12 & 556 & 624 & 675 & 747 & 557 & 632 & 541 \\
\hline
\end{tabular}

Table 12b. ASIAN STEEL PRODUCT PRICE INDEXES (BASED ON USD VALUES)

Tableau 12b. INDICES DE PRIX DES PRODUITS EN ACIER D'ASIE (BASE : VALEUR USD)

\begin{tabular}{|c|c|c|c|c|c|c|c|}
\hline Month & $\begin{array}{l}\text { Hot Rolled } \\
\text { Coil }\end{array}$ & $\begin{array}{c}\text { Hot Rolled } \\
\text { Plate }\end{array}$ & $\begin{array}{l}\text { Cold Rolled } \\
\text { Coil }\end{array}$ & $\begin{array}{c}\text { HD Galv. } \\
\text { Coil }\end{array}$ & $\begin{array}{c}\begin{array}{c}\text { Wire Rod } \\
\text { (mesh) }\end{array}\end{array}$ & $\begin{array}{c}\text { Structural } \\
\text { Sections \& } \\
\text { Beams }\end{array}$ & $\begin{array}{c}\text { Reinforcing } \\
\text { Bar }\end{array}$ \\
\hline 07M1 & 141.1 & 149.3 & 120.3 & 144.1 & 127.2 & 123.0 & 147.5 \\
\hline 07M2 & 143.2 & 149.3 & 121.8 & 143.1 & 130.6 & 126.2 & 151.5 \\
\hline 07M3 & 146.8 & 151.5 & 124.0 & 144.8 & 137.0 & 129.5 & 158.1 \\
\hline 07M4 & 150.2 & 152.3 & 124.0 & 144.0 & 140.4 & 132.2 & 159.7 \\
\hline 07M5 & 152.0 & 155.3 & 125.1 & 144.0 & 144.3 & 134.4 & 161.4 \\
\hline 07M6 & 152.0 & 156.7 & 124.8 & 141.3 & 144.3 & 135.4 & 162.0 \\
\hline 07M7 & 148.6 & 157.5 & 123.7 & 140.1 & 142.8 & 136.1 & 162.0 \\
\hline 07M8 & 149.8 & 158.9 & 124.6 & 141.7 & 144.0 & 137.0 & 163.7 \\
\hline 07M9 & 154.1 & 171.1 & 126.6 & 142.6 & 150.8 & 141.4 & 173.3 \\
\hline 07M10 & 157.7 & 174.7 & 127.2 & 142.4 & 156.6 & 146.0 & 183.2 \\
\hline 07M11 & 159.8 & 177.1 & 129.0 & 145.2 & 161.5 & 147.5 & 185.1 \\
\hline $07 \mathrm{M} 12$ & 165.9 & 182.6 & 133.6 & 145.5 & 170.3 & 152.5 & 192.1 \\
\hline 08M1 & 167.4 & 182.0 & 136.4 & 146.6 & 177.4 & 156.4 & 199.3 \\
\hline 08M2 & 178.9 & 198.9 & 143.4 & 149.4 & 191.1 & 166.3 & 217.2 \\
\hline 08M3 & 211.8 & 223.4 & 170.4 & 160.8 & 204.6 & 185.2 & 242.6 \\
\hline 08M4 & 226.0 & 235.4 & 181.3 & 171.3 & 213.8 & 195.2 & 258.1 \\
\hline 08M5 & 235.6 & 234.3 & 186.7 & 166.0 & 222.9 & 211.1 & 271.0 \\
\hline 08M6 & 261.0 & 255.0 & 206.5 & 182.8 & 245.9 & 227.6 & 287.8 \\
\hline 08M7 & 260.7 & 260.2 & 206.1 & 181.8 & 253.2 & 234.9 & 289.1 \\
\hline 08M8 & 259.8 & 259.4 & 205.4 & 181.1 & 252.6 & 234.1 & 288.1 \\
\hline 08M9 & 237.2 & 250.4 & 188.0 & 170.2 & 249.5 & 227.1 & 260.1 \\
\hline 08M10 & 202.7 & 227.8 & 166.9 & 158.1 & 214.1 & 209.2 & 218.8 \\
\hline 08M11 & 172.2 & 188.3 & 141.2 & 137.5 & 178.6 & 172.4 & 178.2 \\
\hline 08M12 & 167.7 & 180.9 & 137.7 & 130.8 & 160.6 & 149.9 & 184.8 \\
\hline 09M1 & 173.4 & 172.2 & 145.8 & 137.0 & 163.3 & 157.9 & 184.2 \\
\hline 09M2 & 163.4 & 164.9 & 138.1 & 128.5 & 161.8 & 156.7 & 180.2 \\
\hline 09M3 & 145.9 & 153.1 & 125.3 & 117.0 & 145.6 & 143.3 & 157.4 \\
\hline 09M4 & 148.0 & 150.7 & 126.4 & 116.3 & 146.8 & 144.6 & 161.1 \\
\hline 09M5 & 144.1 & 156.1 & 122.2 & 116.8 & 154.7 & 151.8 & 168.3 \\
\hline 09M6 & 148.9 & 163.2 & 129.2 & 121.5 & 153.5 & 146.0 & 169.0 \\
\hline 09M7 & 156.8 & 157.8 & 134.2 & 119.6 & 156.6 & 144.3 & 174.9 \\
\hline 09M8 & 160.4 & 162.7 & 138.6 & 121.0 & 160.2 & 148.4 & 181.8 \\
\hline 09M9 & 163.1 & 167.0 & 141.4 & 130.3 & 160.6 & 152.1 & 178.5 \\
\hline 09M10 & 166.2 & 170.0 & 143.6 & 130.3 & 163.6 & 156.2 & 182.5 \\
\hline 09M11 & 164.0 & 168.7 & 142.7 & 127.3 & 162.7 & 149.6 & 174.6 \\
\hline 09M12 & 168.0 & 170.0 & 147.1 & 130.8 & 170.3 & 153.0 & 178.5 \\
\hline
\end{tabular}

Note: Prices are derived from an arithmetic average of the low transaction values identified in Japan, Taiwan, South Korea and China -

collected in national currencies and converted into US dollars using currency exchange rates effective at the start of each month.

Source: MEPS International Ltd.

THE IRON AND STEEL INDUSTRY IN 2009 - @ OECD 2010 
Table 13. REFERENCE PRICES OF STEELMAKING RAW MATERIALS

Tableau 13. PRIX DE REFERENCE DE MATIERES PREMIERES POUR LA PRODUCTION D'ACIER

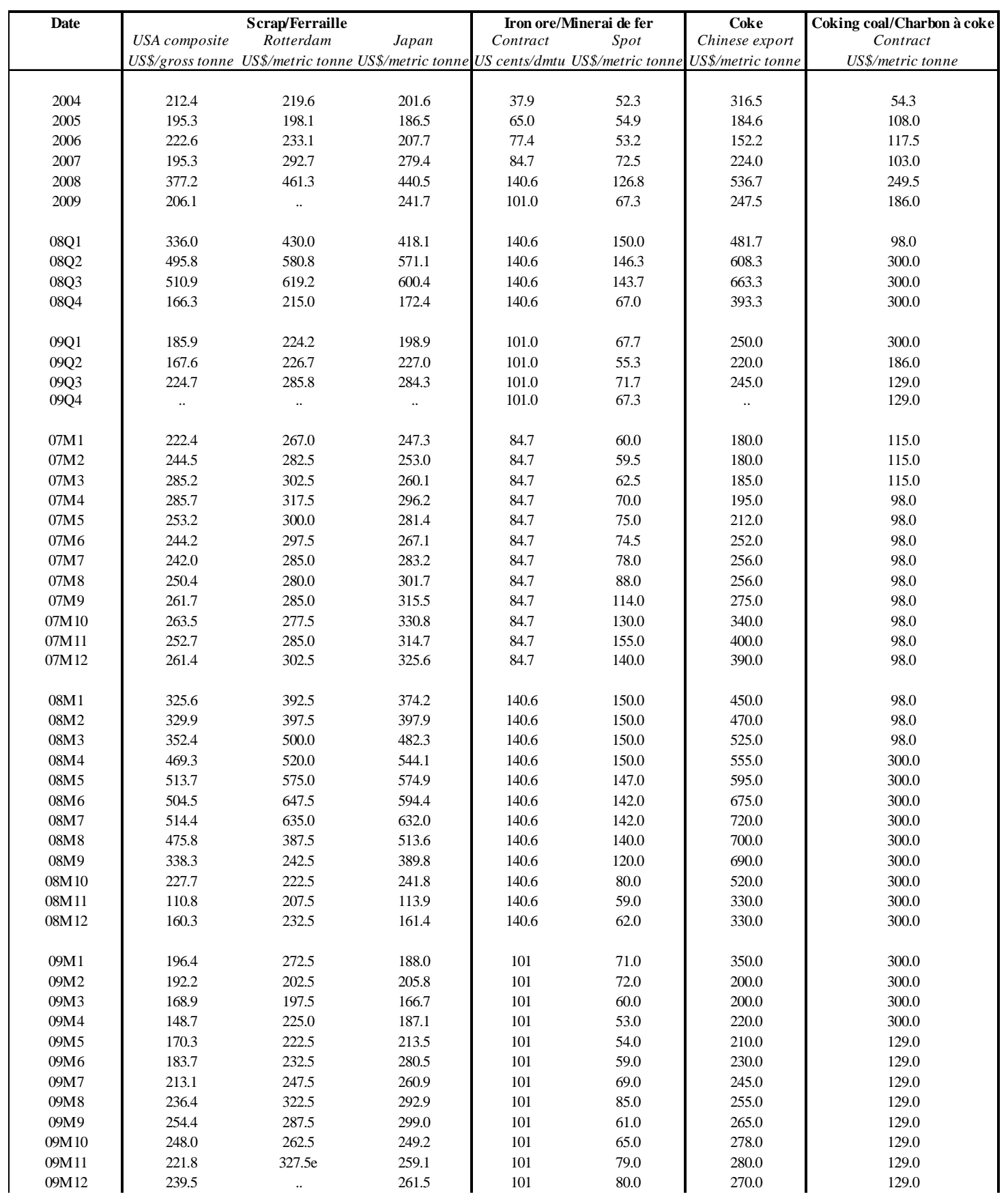

Description of Prices

Scrap (USA Composite), No. 1 heavy melt, weekly average of Chicago, Philadelphia and Pittsburgh.

Scrap (Rotterdam), No. 1 heavy melt, f.o.b. Rotterdam

Scrap (Japan), H2, delivered price, average of Kanto, Chubu and Kansai areas, converted into USD from JPY

Iron ore (contract), $67.55 \%$ iron content, fine, contract price CVRD to Europe, f.o.b. Ponta da Madeira

Iron ore (spot), Indian ore ( $63.5 \% \mathrm{Fe})$ f.o.b.

Coke (Chinese export), $12.5 \%$ ash, Chinese export price f.o.b.

Coking coal (contract), hard coking coal benchmark price of Australian exports to Japanese steel mills, f.o.b.

Sources: IMF Primary Commodity Prices, Steelonthenet, Recycling International, Japan Ferrous Raw Materials Association,

CRU, American Metal Market, ABARE. 
Table 14. WORLD IRON ORE M ARKET BY MAJOR ECONOMY

Tableau 14. LE MARCHE DU MINERAI DE FER DANS LES PRINCIPALES ECONOMIES DU MONDE

Unit : Million tonnes

Unités : Millions de tonnes

\begin{tabular}{|c|c|c|c|c|c|c|c|c|c|c|c|c|c|}
\hline \multirow{4}{*}{$\begin{array}{l}\text { Production } \\
\text { World Total of which: }\end{array}$} & \multicolumn{3}{|c|}{2005} & \multicolumn{3}{|c|}{2006} & \multicolumn{3}{|c|}{2007} & \multicolumn{3}{|c|}{2008} & \\
\hline & Tonnes & \begin{tabular}{|c|}
$\%$ \\
Variation \\
2005-2004 \\
\end{tabular} & $\begin{array}{c}\% \\
\text { du/of } \\
\text { total }\end{array}$ & Tonnes & \begin{tabular}{|c|}
$\%$ \\
Variation \\
$2006-2005$ \\
\end{tabular} & $\begin{array}{c}\% \\
\text { du/of } \\
\text { total } \\
\end{array}$ & Tonnes & \begin{tabular}{c|}
$\%$ \\
Variation \\
$2007-2006$ \\
\end{tabular} & $\begin{array}{c}\% \\
\text { du/of } \\
\text { total }\end{array}$ & Tonnes & \begin{tabular}{|c|}
$\%$ \\
Variation \\
2008-2007 \\
\end{tabular} & $\begin{array}{c}\% \\
\text { du/of } \\
\text { total }\end{array}$ & \\
\hline & & & & & & & & & & & & & Production \\
\hline & 1311.5 & 10.7 & 100.0 & 1494.4 & 13.9 & 100.0 & 1664.0 & 11.3 & 100.0 & 1724.6 & 3.6 & 100.0 & Total Monde dont : \\
\hline Brazil & 292.4 & 8.1 & 22.3 & 318.6 & 9.0 & 21.3 & 336.5 & 5.6 & 20.2 & 346.0 & 2.8 & 20.1 & Brésil \\
\hline China(1) & 197.6 & 35.6 & 15.1 & 276.4 & 39.9 & 18.5 & 365.0 & 32.1 & 21.9 & 366.0 & 0.3 & 21.2 & Chine(1) \\
\hline Australia & 257.5 & 9.7 & 19.6 & 275.1 & 6.8 & 18.4 & 299.0 & 8.7 & 18.0 & 349.8 & 17.0 & 20.3 & Australie \\
\hline Imports & & & & & & & & & & & & & Importationss \\
\hline World Total of which: & 723.7 & 10.1 & 100.0 & 772.6 & 6.8 & 100.0 & 836.4 & 8.3 & 100.0 & 907.3 & 8.5 & 100.0 & Total Monde dont : \\
\hline China & 275.2 & 32.2 & 38.0 & 326.3 & 18.6 & 42.2 & 383.1 & 17.4 & 45.8 & 444.0 & 15.9 & 48.9 & Chine \\
\hline Japan & 132.3 & -1.9 & 18.3 & 134.4 & 1.6 & 17.4 & 138.9 & 3.3 & 16.6 & 140.4 & 1.1 & 15.5 & Japon \\
\hline Germany & 42.0 & -9.5 & 5.8 & 44.9 & 6.9 & 5.8 & 46.2 & 2.9 & 5.5 & 44.3 & -4.1 & 4.9 & Allemagne \\
\hline Exports & & & & & & & & & & & & & Exportations \\
\hline World Total of which: & 716.3 & 11.2 & 100.0 & 762.3 & 6.4 & 100.0 & 823.4 & 8.0 & 100.0 & 881.8 & 7.1 & 100.0 & Total M onde dont : \\
\hline Australia & 239.0 & 8.0 & 33.4 & 247.3 & 3.5 & 32.4 & 266.9 & 7.9 & 32.4 & 309.3 & 15.9 & 35.1 & Australie \\
\hline Brazil & 223.4 & 11.2 & 31.2 & 247.5 & 10.8 & 32.5 & 269.4 & 8.8 & 32.7 & 281.7 & 4.6 & 31.9 & Brésil \\
\hline India & 80.9 & 29.0 & 11.3 & 89.3 & 10.4 & 11.7 & 93.7 & 4.9 & 11.4 & 101.4 & 8.2 & 11.5 & Inde \\
\hline Apparent consumption & & & & & & & & & & & & & Consommation apparente \\
\hline World Total of which: & 1323.4 & 10.5 & 100.0 & 1508.3 & 14.0 & 100.0 & 1643.3 & 9.0 & 100.0 & e 1750.1 & 6.5 & 100.0 & Total Monde dont : \\
\hline China & 472.8 & 33.6 & 35.7 & 602.8 & 27.5 & 40.0 & 715.4 & 18.7 & 43.5 & e 810.0 & 13.2 & 46.3 & Chine \\
\hline Japan & 132.3 & -1.9 & 10.0 & 134.4 & 1.6 & 8.9 & 138.9 & 3.3 & 8.5 & e 140.4 & 1.1 & 8.0 & Japon \\
\hline India & 63.1 & 7.1 & 4.8 & 92.4 & 46.4 & 6.1 & 114.3 & 23.7 & 7.0 & e 113.2 & -1.0 & 6.5 & Inde \\
\hline
\end{tabular}

(1) Chinese iron ore production is converted, so that its iron content is about equal to that in the rest of the world on average.

(1) La production de minerai de fer chinois est convertie de façon à être comparable en moyenne à celle du reste du monde.

Source: UNCTAD/CNUCED

THE IRON AND STEEL INDUSTRY IN 2009 - @ O OECD 2010 
Table 15. WORLD COKE MARKET BY MAJOR ECONOMY

Unit : Million tonnes

Tableau 15. LEMARCHE DU COKEDANS LES PRINCIPALES ECONOMIES DU MONDE

\begin{tabular}{|c|c|c|c|c|c|c|c|c|c|c|c|c|c|}
\hline \multirow{4}{*}{$\begin{array}{l}\text { Production } \\
\text { OECD + China }\end{array}$} & \multicolumn{3}{|c|}{2005} & \multicolumn{3}{|c|}{2006} & \multicolumn{3}{|c|}{2007} & \multicolumn{3}{|c|}{2008} & \\
\hline & Tonnes & \begin{tabular}{c|}
$\%$ \\
Variation \\
$2005-2004$ \\
\end{tabular} & $\begin{array}{c}\% \\
\text { du/of } \\
\text { total }\end{array}$ & Tonnes & \begin{tabular}{c|}
$\%$ \\
Variation \\
$2006-2005$ \\
\end{tabular} & $\begin{array}{c}\% \\
\text { du/of } \\
\text { total }\end{array}$ & Tonnes & $\begin{array}{c}\% \\
\text { Variation } \\
2007-2006 \\
\end{array}$ & $\begin{array}{c}\% \\
\text { du/of } \\
\text { total }\end{array}$ & Tonnes & \begin{tabular}{c|}
$\%$ \\
Variation \\
$2008-2007$ \\
\end{tabular} & $\begin{array}{c}\% \\
\text { du/of } \\
\text { total } \\
\end{array}$ & \\
\hline & & & & & & & & & & & & & Production \\
\hline & 365.0 & 8.1 & 100.0 & 411.1 & 12.6 & 100.0 & 466.1 & 13.4 & 100.0 & 450.0 & -3.5 & 100.0 & $\mathrm{OCDE}+$ Chine \\
\hline China & 239.0 & 14.4 & 65.5 & 281.4 & 17.7 & 68.5 & 328.9 & 16.9 & 70.6 & 323.6 & -1.6 & 71.9 & Chine \\
\hline Japan & 42.6 & 2.2 & 11.7 & 43.7 & 2.6 & 10.6 & 50.4 & 15.2 & 10.8 & 42.5 & -15.6 & 9.4 & Japon \\
\hline United States & 15.2 & -1.1 & 4.2 & 14.9 & -1.9 & 3.6 & 14.7 & -1.2 & 3.2 & 14.1 & -4.1 & 3.1 & Etats-Unis \\
\hline Imports & & & & & & & & & & & & & Importations \\
\hline OECD + China & 18.5 & -22.8 & 100.0 & 19.0 & 2.6 & 100.0 & 18.7 & -1.6 & 100.0 & 19.1 & 2.1 & 4.2 & OCDE + Chine \\
\hline Germany & 3.8 & -14.0 & 20.5 & 3.7 & -2.8 & 19.4 & 4.7 & 27.3 & 25.1 & 4.3 & -8.4 & 1.0 & Allemagne \\
\hline United States & 3.2 & -48.7 & 17.3 & 3.7 & 15.2 & 19.4 & 2.2 & -39.5 & 11.9 & 3.3 & 47.9 & 0.7 & Etats-Unis \\
\hline Japan & 2.5 & -15.3 & 13.5 & 1.8 & -27.8 & 9.5 & 2.0 & 10.6 & 10.7 & 1.4 & -29.9 & 0.3 & Japon \\
\hline $\begin{array}{l}\text { Exports } \\
\text { OECD + China }\end{array}$ & 24.1 & -13.5 & 100.0 & 29.0 & 20.1 & 100.0 & 28.9 & -0.2 & 100.0 & 25.1 & -13.1 & 5.6 & $\begin{array}{l}\text { Exportations } \\
\text { OCDE + Chine }\end{array}$ \\
\hline China & 12.9 & -14.6 & 53.4 & 14.6 & 13.1 & 50.3 & 15.3 & 5.2 & 53.1 & 12.1 & -21.1 & 2.7 & Chine \\
\hline Poland & 4.6 & -12.1 & 19.2 & 6.3 & 36.5 & 21.8 & 6.3 & 0.2 & 21.9 & 6.0 & -5.1 & 1.3 & Pologne \\
\hline Japan & 1.7 & -17.7 & 6.9 & 2.0 & 17.4 & 6.8 & 1.4 & -28.8 & 4.8 & 0.9 & -35.7 & 0.2 & Japon \\
\hline $\begin{array}{l}\text { Apparent consumption } \\
\text { OECD + China }\end{array}$ & 357.8 & 7.0 & 100.0 & 402.2 & 12.4 & 100.0 & 457.0 & 13.6 & 100.0 & 443.0 & -3.1 & 98.4 & $\begin{array}{l}\text { Consommation apparente } \\
\text { OCDE + Chine }\end{array}$ \\
\hline China & 226.1 & 16.6 & 63.2 & 266.8 & 18.0 & 66.3 & 313.6 & 17.5 & 68.6 & 311.5 & -0.7 & 69.2 & Chine \\
\hline Japan & 43.2 & 0.6 & 12.1 & 44.4 & 2.9 & 11.0 & 45.5 & 2.4 & 10.0 & 42.0 & -7.7 & 9.3 & Japon \\
\hline United States & 16.5 & -18.9 & 4.6 & 17.0 & 3.0 & 4.2 & 15.7 & -8.1 & 3.4 & 15.4 & -1.7 & 3.4 & Etats-Unis \\
\hline
\end{tabular}

Source: IEA/AIE, TEX Report, Chinese Customs Statistics, CRU International, OECD Secretariat/Secrétariat de l'OCDE. 
Table 16. WORLD COKING COAL MARKET BY MAJOR ECONOMY

Tableau 16. LE MARCHE DU CHARBON A COKE DANS LES PRINCIPALES ECONOMIES DU MONDE

Unit : Million tonnes

Unités : Millions de tonnes

Production

World Total of which:

China

Australia

Russia

Imports

World Total of which

Japan

Korea

India

Exports

World Total of which:

Australia

United States

Russia

Apparent consumption World Total of which:

China

Japan

Russia

\begin{tabular}{|c|c|c|c|c|c|c|c|c|c|c|c|}
\hline \multicolumn{3}{|c|}{2005} & \multicolumn{3}{|c|}{2006} & \multicolumn{3}{|c|}{2007} & \multicolumn{3}{|c|}{2008} \\
\hline Tonnes & $\begin{array}{c}\% \\
\text { Variation } \\
2005-2004 \\
\end{array}$ & $\begin{array}{c}\% \\
\text { du/of } \\
\text { total }\end{array}$ & Tonnes & $\begin{array}{c}\% \\
\text { Variation } \\
2006-2005 \\
\end{array}$ & $\begin{array}{c}\% \\
\text { du/of } \\
\text { total }\end{array}$ & Tonnes & \begin{tabular}{c|}
$\%$ \\
Variation \\
$2007-2006$ \\
\end{tabular} & $\begin{array}{c}\% \\
\text { du/of } \\
\text { total }\end{array}$ & Tonnes & \begin{tabular}{|c|}
$\%$ \\
Variation \\
2008-2007 \\
\end{tabular} & $\begin{array}{c}\% \\
\text { du/of } \\
\text { total }\end{array}$ \\
\hline 651.5 & 10.1 & 100.0 & 716.2 & 9.9 & 100.0 & 786.6 & 9.8 & 100.0 & 854.4 & 8.6 & 100.0 \\
\hline 280.6 & 24.3 & 43.1 & 339.0 & 20.8 & 47.3 & 379.1 & 11.8 & 48.2 & 427.4 & 12.7 & 50.0 \\
\hline 128.3 & 8.9 & 19.7 & 124.0 & -3.4 & 17.3 & 141.8 & 14.4 & 18.0 & 140.1 & -1.2 & 16.4 \\
\hline 55.5 & -9.2 & 8.5 & 54.0 & -2.7 & 7.5 & 57.4 & 6.2 & 7.3 & 65.1 & 13.4 & 7.6 \\
\hline 194.4 & -4.1 & 100.0 & 196.0 & 0.8 & 100.0 & 206.9 & 5.6 & 100.0 & 222.5 & 7.5 & 100.0 \\
\hline 56.5 & -7.2 & 29.1 & 57.7 & 2.0 & 29.4 & 58.2 & 0.9 & 28.1 & 57.4 & -1.4 & 6.7 \\
\hline 20.6 & -5.4 & 10.6 & 20.1 & -2.6 & 10.2 & 22.5 & 12.2 & 10.9 & 24.0 & 6.5 & 2.8 \\
\hline 16.9 & -0.2 & 8.7 & 17.9 & 5.8 & 9.1 & 22.0 & 23.1 & 10.6 & 28.8 & 30.9 & 3.4 \\
\hline 213.0 & 8.1 & 100.0 & 220.9 & 3.7 & 100.0 & 238.8 & 8.1 & 100.0 & 261.8 & 9.6 & 100.0 \\
\hline 123.9 & 10.9 & 58.2 & 119.3 & -3.7 & 54.0 & 131.2 & 10.0 & 54.9 & 136.9 & 4.3 & 16.0 \\
\hline 26.0 & 6.8 & 12.2 & 24.9 & -4.1 & 11.3 & 29.2 & 17.0 & 12.2 & 38.6 & 32.2 & 4.5 \\
\hline 10.0 & -16.4 & 4.7 & 10.0 & 0.2 & 4.5 & 10.0 & -0.1 & 4.2 & 15.5 & 55.0 & 1.8 \\
\hline 627.4 & 7.0 & 100.0 & 691.2 & 10.2 & 100.0 & 744.2 & 7.7 & 100.0 & 813.8 & 9.4 & 100.0 \\
\hline 282.4 & 25.3 & 45.0 & 339.6 & 20.3 & 49.1 & 381.1 & 12.2 & 51.2 & 433.0 & 13.6 & 50.7 \\
\hline 56.5 & -7.2 & 9.0 & 57.7 & 2.0 & 8.3 & 58.2 & 0.9 & 7.8 & 57.4 & -1.4 & 6.7 \\
\hline 45.0 & -8.5 & 7.2 & 44.6 & -0.8 & 6.5 & 46.5 & 4.2 & 6.2 & 49.6 & 6.7 & 5.8 \\
\hline
\end{tabular}

\section{Production}

Total Monde dont :

Chine

Australie

Russie

Importationss

Total Monde dont :

Japon

Corée

Inde

Exportations

Total Monde dont :

Australie

Etats-Unis

Russie

Consommation apparente

Total Monde dont

Chine

Japon

Russie

Sources: IEA, ABARE estimates/estimations de l'AIE et de ABARE Note: $e=$ estimatelestimation 
Table 17. WORLD SCRAP MARKET BY MAJOR ECONOMY

Tableau 17. LE MARCHE DE LA FERRAILLE DANS LES PRINCIPALES ECONOMIES DU MONDE

Unit : Million tonnes

Unités : Millions de tonnes

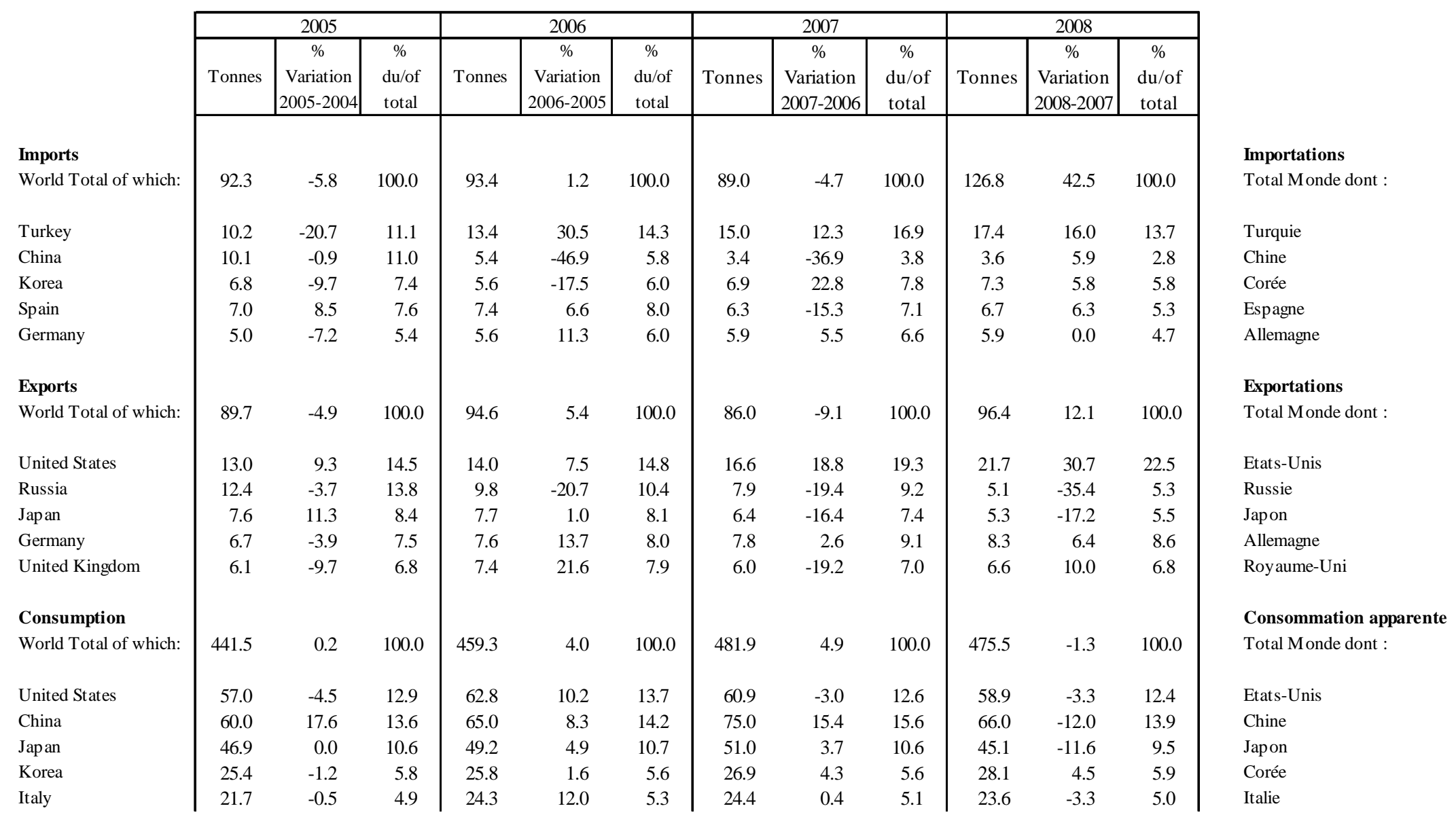

Source: World Steel Association/Association Mondiale de l'Acier 


\section{Table 18. EFFECTIVE CAPACITY FOR THE PRODUCTION OF PIG IRON AND FORECASTS Tableau 18. CAPACITE EFFECTIVE DE PRODUCTION DE FONTE ET PREVISIONS}

\begin{tabular}{|c|c|c|c|c|c|c|}
\hline Country & 2006 & 2007 & 2008 & $2009 \mathrm{e}$ & $2010 f$ & Pays \\
\hline Germany & 33257 & 31895 & 32160 & 32321 & 32472 & Allemagne \\
\hline Belgium & 8000 & 8000 & 8000 & 9300 & 9300 & Belgique \\
\hline Spain & 4300 & .. & .. & .. & .. & Espagne \\
\hline Finland & 3200 & 3300 & 3300 & 3300 & .. & Finlande \\
\hline France & 14492 & .. & .. & .. & .. & France \\
\hline Greece & 800 & 800 & 800 & 800 & .. & Grèce \\
\hline Hungary & 1350 & 1350 & 1350 & 1350 & .. & Hongrie \\
\hline Italy & 15200 & .. & .. & .. & .. & Italie \\
\hline Luxembourg & - & - & - & - & - & Luxembourg \\
\hline Netherlands & 6000 & .. & .. & .. & .. & Pays Bas \\
\hline Poland & 6000 & 6000 & 6000 & 6000 & .. & Pologne \\
\hline Portugal & - & - & - & - & - & Portugal \\
\hline Czech Republic & 5192 & 5282 & 5300 & .. & .. & République Tchèque \\
\hline Slovak Republic & 4500 & 4500 & 4500 & 4500 & .. & République Slovaque \\
\hline United Kingdom & 11500 & 12400 & 12400 & 12400 & 12400 & Royaume Uni \\
\hline Sweden & 3900 & .. & .. & .. & .. & Suède \\
\hline $\mathrm{UE}(25)(\mathrm{e})$ & 129000 & 130000 & 131000 & 131000 & .. & $\mathrm{UE}(25)(\mathrm{e})$ \\
\hline Norway & 100 & 100 & 100 & 100 & .. & Norvège \\
\hline Switzerland & 1200 & 1200 & 1200 & 1200 & .. & Suisse \\
\hline Turkey & .. & .. & 8060 & 8300 & 10750 & Turquie \\
\hline Canada & 10000 & 10000 & 10500 & 10500 & 10500 & Canada \\
\hline Mexico & 9372 & 9940 & 10638 & 11028 & .. & Mexique \\
\hline United States & .. & .. & .. & .. & .. & Etats Unis \\
\hline Japan & 83343 & .. & .. & .. & .. & Japon \\
\hline Korea & 27140 & 29140 & 31140 & .. & .. & Corée \\
\hline Brazil (1) & 26373 & 31274 & 31274 & 36300 & .. & Brésil (1) \\
\hline Romania & 6000 & 6000 & 6000 & 6000 & 6000 & Roumanie \\
\hline Argentina & 2850 & .. & .. & .. & .. & Argentine \\
\hline Bulgaria & 1625 & 850 & 850 & 850 & .. & Bulgarie \\
\hline Chinese Taïpei & 9250 & 9550 & 9550 & 9550 & .. & Taïpei Chinois \\
\hline Russia & 57000 & 57000 & 57000 & .. & .. & Russie \\
\hline
\end{tabular}

(1) Brazil/Brésil : Only AF/BOF integrated steel plants capacity. Independent producers are not included

$\mathbf{e}=$ estimate/estimations

$\mathbf{f}=$ forecast $/$ prévision

Source: OECD Secretariat/Secrétariat de l'OCDE 
Table 19. WORLD CRUDE STEELMAKING CAPACITY

Tableau 19. CAPACITE MONDIALE D'ACIER BRUT

Unit : Million tonnes

\begin{tabular}{|c|c|c|c|c|c|c|c|c|c|c|}
\hline & \multicolumn{3}{|c|}{2008} & \multicolumn{3}{|c|}{2009} & \multicolumn{3}{|c|}{$2010 \mathrm{f}$} & \\
\hline & Tonnes & $\begin{array}{c}\% \\
\text { Variation } \\
2008-2007\end{array}$ & $\begin{array}{c}\% \\
\text { du/of } \\
\text { total }\end{array}$ & Tonnes & \begin{tabular}{|c|}
$\%$ \\
Variation \\
$2009-2008$
\end{tabular} & $\begin{array}{c}\% \\
\text { du/of } \\
\text { total }\end{array}$ & Tonnes & $\begin{array}{c}\% \\
\text { Variation } \\
2010-2009\end{array}$ & $\begin{array}{c}\% \\
\text { du/of } \\
\text { total }\end{array}$ & \\
\hline World Total of which: & 1702.3 & 16.7 & 100.0 & 1806.0 & 11.2 & 100.0 & 1888.0 & 10.9 & 100.0 & Monde Total dont : \\
\hline Europe of which: & 285.1 & 2.2 & 16.7 & 288.4 & 1.2 & 16.0 & 292.5 & 1.4 & 15.5 & Europe dont : \\
\hline Germany & 53.2 & 0.6 & 3.1 & 54.2 & 1.9 & 3.0 & 55.4 & 2.2 & 2.9 & Allemagne \\
\hline Italy &.. & .. & .. & .. &.. & .. & .. &.. & .. & Italie \\
\hline France & 24.0 & .. & .. & 22.5 & .. & .. & .. &.. & .. & France \\
\hline Spain & .. & .. & .. & .. & .. & .. & .. &.. &.. & Espagne \\
\hline United Kingdom & 17.8 & 0.0 & 1.0 & 17.8 & 0.0 & 1.0 & 17.8 & 0.0 & 0.9 & Royaume-Uni \\
\hline Canada & 19.0 & 0.0 & 1.1 & 19.0 & 0.0 & 1.1 & 19.0 & 0.0 & 1.0 & Canada \\
\hline Mexico & 21.8 & 0.5 & 1.3 & 21.9 & 0.5 & 1.2 & 21.9 & 0.0 & 1.2 & Mexique \\
\hline United States & 111.9 & -1.3 & 6.6 & 114.3 & 2.1 & 6.3 & 115.1 & 0.7 & 6.1 & Etats-Unis \\
\hline Japan & 129.8 & 0.9 & 7.6 & 132.4 & 2.0 & 7.3 & 132.0 & -0.3 & 7.0 & Japon \\
\hline Korea & 60.1 & 2.6 & 3.3 & 64.2 & 0.0 & 3.1 & 70.0 & 0.0 & 3.0 & Corée \\
\hline Brazil & 41.8 & 0.7 & 2.5 & 43.1 & 3.1 & 2.4 & 47.7 & 10.7 & 2.5 & Brésil \\
\hline CIS of which: & 148.8 & 5.7 & 8.7 & 151.5 & 1.7 & 8.4 & 154.4 & 1.9 & 8.2 & CEI dont : \\
\hline Russia & 82.7 & 5.1 & 4.9 & 84.5 & 2.2 & 4.7 & 86.1 & 1.9 & 4.6 & Russie \\
\hline Ukraine & 53.1 & 7.5 & 3.1 & 53.1 & 0.0 & 2.9 & 54.4 & 2.4 & 2.9 & Ukraine \\
\hline India & 59.1 & 5.3 & 3.5 & 67.7 & 14.6 & 3.7 & 77.0 & 13.7 & 4.1 & Inde \\
\hline China & 665.0 & 9.0 & 39.1 & 730.0 & 9.8 & 40.4 & 765.0 & 4.8 & 40.5 & Chine \\
\hline Other economies & 163.9 & 2.6 & 9.6 & 181.7 & 10.9 & 10.1 & 207.4 & 14.1 & 11.0 & Autres économies \\
\hline
\end{tabular}

Note $\mathrm{f}=$ forecast/prévision

Source: OECD Secretariat/Secrétariat de l'OCDE 